\title{
A Planning Framework for Transferring Building Energy Technologies
}

\author{
Barbara C. Farhar \\ Marilyn A. Brown \\ Bryan L. Mohler \\ Michael Wilde \\ Fred H. Abel
}

July 1990

Prepared for the Office of Building Technologies U.S. Department of Energy Under Task No. AS925440

Solar Energy Research Institute A Division of Midwest Research Institute

1617 Cole Boulevard

Golden, Colorado 80401-3393

Prepared for the U.S. Department of Energy

Contract No. DE-AC02-83CH10093 


\section{NOTICE}

This report was prepared as an account of work sponsored by an agency of the United States government. Neither the United States government nor any agency thereof, nor any of their employees, makes any warranty, express or implied, or assumes any legal liability or responsibility for the accuracy, completeness, or usefulness of any information, apparatus, product, or process disclosed, or represents that its use would not infringe privately owned rights. Reference herein to any specific commercial product, process, or service by trade name, trademark, manufacturer, or otherwise does not necessarily constitute or imply its endorsement, recommendation, or favoring by the United States government or any agency thereof. The views and opinions of authors expressed herein do not necessarily state or reflect those of the United States government or any agency thereof.

Printed in the United States of America

Available from:

National Technical Information Service

U.S. Department of Commerce

5285 Port Royal Road

Springfield, VA 22161

Price: Microfiche A01

Printed Copy A09

Codes are used for pricing all publications. The code is determined by the number of pages in the publication. Information pertaining to the pricing codes can be found in the current issue of the following publications which are generally available in most libraries: Energy Research Abstracts (ERA); Government Reports Announcements and Index (GRA and I); Scientific and Technical Abstract Reports (STAR); and publication NTIS-PR-360 available from NTIS at the above address. 


\section{PREFACE}

On April 19, 1990, the Assistant Secretary for Conservation and Renewable Energy (CE), J. Michael Davis, announced a reorganization of his office within the U.S. Department of Energy (DOE). The Office of Building and Community Systems (OBCS), for which this study was conducted, was replaced by an Office of Building Technologies (OBT), headed by Deputy Assistant Secretary John P. Millhone. Within OBT, three offices now exist: (1) the Office of Buildings Energy Research (OBER), (2) the Office of Codes and Standards (OCS), and (3) the Office of the Federal Energy Management Program (FEMP).

The results of the planning effort described in this report apply to OBT programs in a crosscutting sense. Technology transfer functions may, in the future, be located in a different unit within the CE organization as a result of the reorganization; however, the recommendations of this report apply regardless of the organizational unit in which technology transfer functions reside. Therefore, references to the building-energy-efficiency R\&D program are now made by referring to OBT and are intended, in general, to include the crosscutting aspects of technology transfer for that program.

The Office of State and Local Assistance Programs (OSLAP), also mentioned in this study, was included in the reorganization at DOE. In its stead, an Office of Technical and Finanacial Assistance (OTFA) has been formed. Three offices report to Frank Stewart, the Deputy Assistant Secretary for Technical and Financial Assistance: (1) The Office of National Programs, including the Energy-Related Inventions Program (ERIP); (2) the Office of Grants Management, including the Weatherization Assistance Program (WAP) and the Institutional Conservation Program (ICP); and (3) the Office of Technical Assistance; incorporating federal information programs.

A DOE and U.S. Department of Housing and Urban Development (HUD) joint initiative is another significant development relevant to this study. The potential for joint DOE/HUD activities is explored in this report. The agencies currently plan to work together to save energy and improve comfort in a wide range of HUD programs mentioned in this report. The joint initiative is expected to reduce federal expenditures for energy and reduce emissions of gases damaging to the environment. A $25 \%$ energy savings in public housing nationwide, for example, could provide savings of approximately $\$ 200$ million while increasing occupants' comfort. Emissions could be reduced by more than 3 million tons of carbon dioxide, 8,000 tons of sulfur dioxide, and 5,000 tons of nitrogen oxides. The DOEHUD agreement was put in motion by an exchange of letters between W. Henson Moore, Deputy Secretary, DOE, and Jack Kemp, Secretary, HUD. The cooperative program will be directed by J. Michael Davis, DOE, and Anna Kondratas, Assistant Seçretary, Community Planning and Development, HUD.
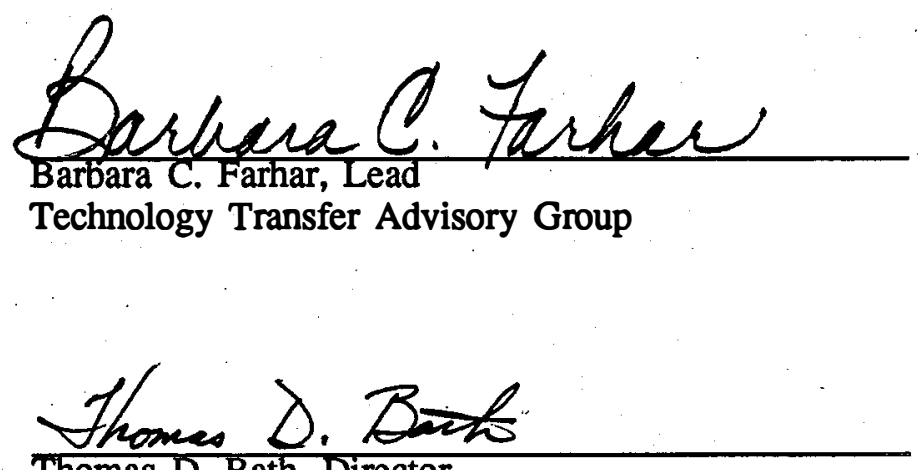

Thomas D. Bath, Director

Energy and Environmental Analysis Division

Solar Energy Research Institute 


\section{ACKNOWLEDGMENTS}

The Office of Building Technologies gives special thanks to the Solar Energy Research Institute for coordinating the Interlaboratory Advisory Group on Technology Transfer and to Lawrence Berkeley Laboratory, Oak Ridge National Laboratory, and Pacific Northwest Laboratory for their technical support to this document.

Members of the interlaboratory Technology Transfer Advisory Group were

Fred H. Abel, U.S. Department of Energy

Martin Broders, Oak Ridge National Laboratory

Marilyn A. Brown, Oak Ridge National Laboratory

Barbara C. Farhar, Solar Energy Research Institute (lead)

Bryan L. Mohler, Pacific Northwest Laboratory

Dana Moran, Solar Energy Research Institute

Robert Noun, Solar Energy Research Institute

Michael Wilde, Lawrence Berkeley Laboratory

Doris Delaney assisted the Technology Transfer Advisory Group. 


\section{CONTENTS}

$\underline{\text { Page }}$

Executive Summary $\ldots \ldots \ldots \ldots \ldots \ldots \ldots \ldots \ldots \ldots \ldots \ldots$ viii

Glossary ............................... xiv

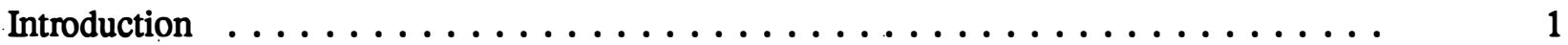

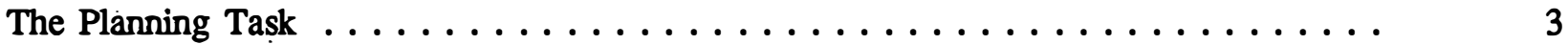

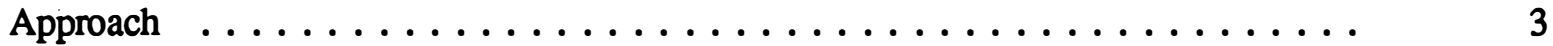

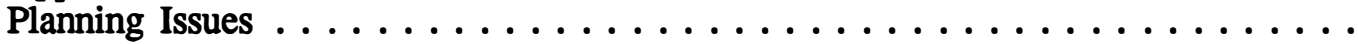

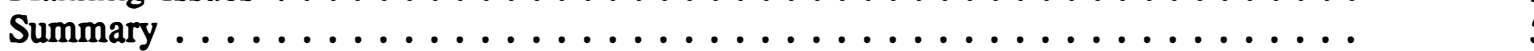

Background and Context $\ldots \ldots \ldots \ldots \ldots \ldots \ldots \ldots \ldots \ldots \ldots \ldots \ldots \ldots \ldots \ldots \ldots \ldots$

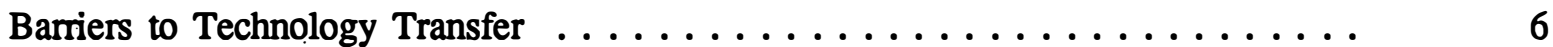

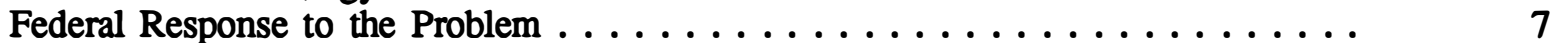

National Energy Strategy Assessment of Technology Transfer . . . . . . . . . . $\quad 9$

Existing Technology Transfer Strategies and Mechanisms . . . . . . . . . . 9

Evaluating Technology Transfer ....................... 11

Technology Transfer Concepts, Models, and Processes ............... 11

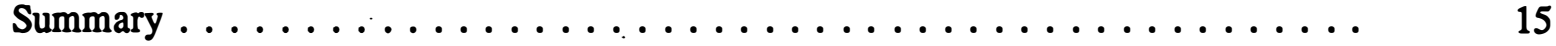

The Existing Technology Transfer Program . . . . . . . . . . . . . . . . . 16

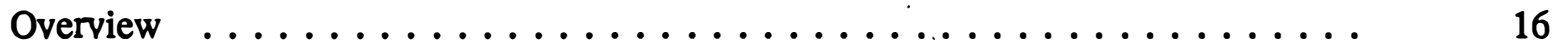

Standing and Special-Purpose Review Committees . . . . . . . . . . . . . . . . 19

Program Manager Views . . . . . . . . . . . . . . . . . . . . . . . . . 19

Common Themes from the Interviews .................... 19

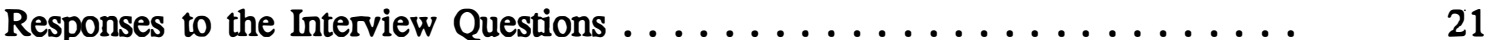

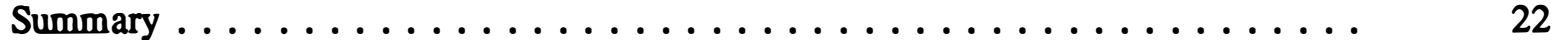

What Needs To Be Transferred? Technologies, Tools, and Practices . . . . . . . . . 24

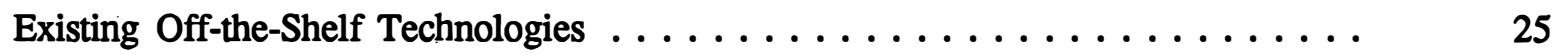

Technologies Almost Ready for Transfer . . . . . . . . . . . . . . . 26

Summary ............................. 26

To Whom Are Energy Efficiency Technologies for Buildings Transferred? . . . . . . . . 28

Key Functional Audiences . . . . . . . . . . . . . . . . . . . . 28

Program Networks and Linkages: Potential and Actual . . . . . . . . . . . . . 32

Results of Organizational Discussions . . . . . . . . . . . . . . . . . 34

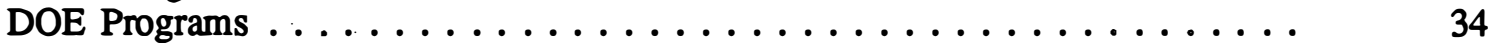

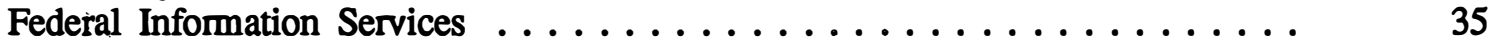

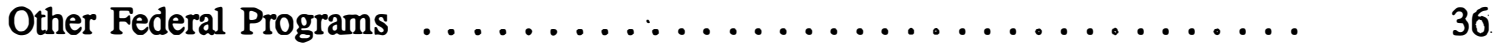

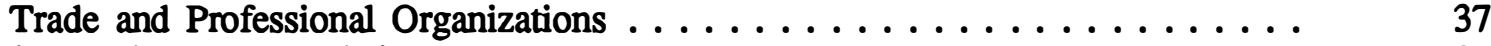

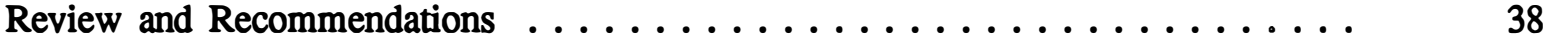

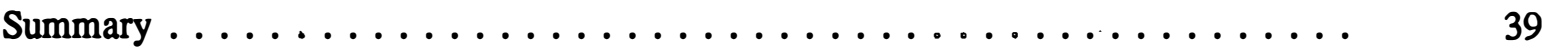


CONTENTS (Concluded)

$\underline{\text { Page }}$

Decision Processes for Technology Transfer Activities . . . . . . . . . . . . . . 40

Criteria ............................ 40

Budget Cycles .............................. $4 \ldots \ldots$

Program Review ........................... 41

Internal OBT Management Review .................... 41

Technology Transfer Roundtable(s) . . . . . . . . . . . . . . . . . . 41

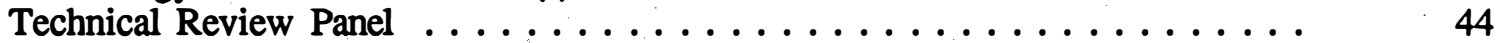

Summary ................................ 44

Frameworks for Deciding on Office-Wide Technology Transfer Activities _ . . . . . . 46

OBT Technology Transfer Functions $\ldots \ldots \ldots \ldots \ldots \ldots \ldots \ldots \ldots$

A Framework for Assessing Technology Transfer through

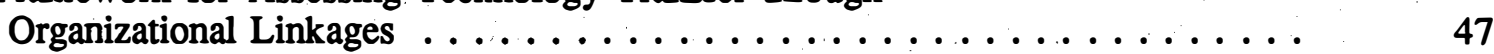

Examples of Technology Transfer Activities ...................... 48

A Framework for Assessing Technology Transfer Activities . . . . . . . . . . . . 50

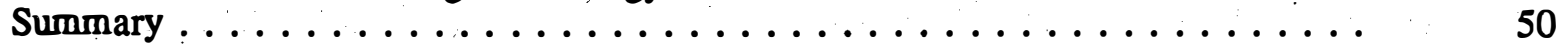

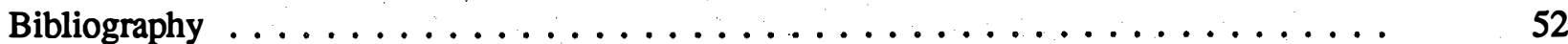

Appendix A: $\quad$ Abbreviated List of Recent DOE Building Energy Technology

Transfer Organizations, Products, Events, Reports and

Projects, and Analysis Projects . . . . . . . . . . . . .

Appendix B: Tools, Technologies, and Practices for Transfer . . . . . . . . . 63

Appendix C: $\quad$ Transferring Building Energy Technologies by Linking Government and Private-Sector Programs .............. 75

Appendix D: $\quad$ Framework Used to Identify Organizational Linkages . . . . . . . . . 133

Appendix E: Examples of Technology Transfer Activities and Their

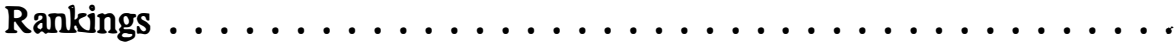

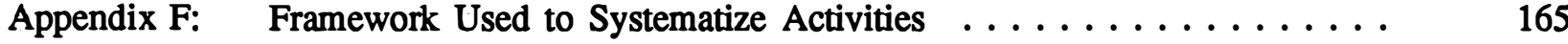




\section{LIST OF TABLES}

$\underline{\text { Page }}$

Table 1. National Laboratory Technology Transfer Processes and

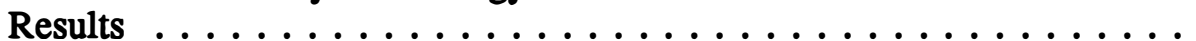

Table 2. Distribution of A\&TT Activities by Intended Audiences . . . . . . . 18

Table 3. Functional Audiences by BCS Division $\ldots \ldots \ldots \ldots \ldots \ldots$

Table 4. Matrix of Technology Transfer Functions by Target Audiences 49

Table B-1. Successfully Commercialized Off-the-Shelf Technologies

Requiring No Further Assistance . . . . . . . . . . . . . . 65

Table B-2. Examples of Best Off-the-Shelf Buildings Technologies 66

Table B-3. Tools, Technologies, and Practices Almost Ready for

Commercialization and Needing Assistance $\ldots \ldots \ldots \ldots \ldots$

Table B-4. Tools, Technologies, and Practices Almost Ready for

Commercialization, Not Needing Assistance . . . . . . . . . . . .

Table D-1. Existing and Proposed Technology Transfer Activities

Table D-2. Organizational Leverage Points for OBT Linkages

(Actual and Potential) ..................... 136

Table F-1. Existing and Proposed Technology Transfer Activities _ . . . . . . . 167

Table F-2. Technology Transfer Activities $\ldots \ldots \ldots \ldots \ldots \ldots \ldots \ldots$

\section{LIST OF FIGURES}

Figure 1. Technology Transfer Strategy by Stage of Technology

Development for One Example Technology . . . . . . . . . . .

Figure 2. Overlapping Stages in the Technology Development and

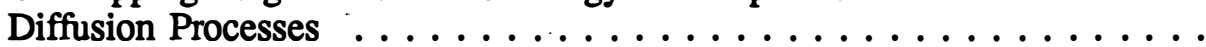

Figure 3. Potential Sequencing of Technology Transfer Functions . . . . . . . . . 


\section{EXECUTIVE SUMMARY}

After the Oil Producing and Exporting Countries (OPEC) oil embargo in 1973-74, energy efficiency in U.S. buildings improved substantially. The known benefits of energy efficiency in buildings, transportation, and industry include saving finite energy supplies, reducing the cost of energy services, improving national security, improving the competitiveness of U.S. industry, reducing acid rain, slowing global climate change, and reducing ozone depletion. However, efficiency gains have been reversed in the past 3 years, and future increases in building energy use are anticipated. Although the technological potential for reducing the amount of energy consumed in buildings remains significant--on the order of $25 \%$ for existing buildings and $50 \%$ for new buildings with technologies that already exist--the impediments to actualizing that potential lie in the technology transfer arena. For energy efficiency to contribute to its full potential, diverse intermediaries and consumers will have to decide to invest in it. Market availability and acceptance are pivotal to an effective role for building energy efficiency in the national energy equation.

This report presents the results of an interlaboratory planning effort in support of the U.S. Department of Energy's (DOE's) Office of Building Technologies (OBT) (formerly the Office of Buildings and Community Systems) and its Analysis and Technology Transfer (A\&TT) Program. OBT manages the nation's energy technology research and development (R\&D) program in buildings. This effort dealt specifically with technology transfer related to energy efficiency in buildings, and particularly with the aspects of technology transfer that cut across the entire OBT program. Less attention is given to technology transfer issues that are particular to individual projects.

\section{Approach}

Transfer of energy efficiency technologies in buildings can be accomplished rapidly by using mandatory standards and regulations. This study is based on the assumption that such regulation would not occur; it addresses how to accomplish technology transfer effectively without mandatory processes. This is a much more difficult problem. Although OBT has already successfully transferred some technology, OBT management decided that planning was needed to explore ways to increase the Office's effectiveness in this area. A guiding assumption for planning was that OBT's program, as an R\&D program, should forge linkages with already existing programs whose goals involved actually enhancing energy efficiency in buildings.

An ad hoc Technology Transfer Advisory Group, which included representatives from OBT management and four national laboratories, reviewed the current program, brainstormed technology transfer approaches, identified applicable research results and references, and developed a framework that management could use in deciding on the best investments of technology transfer resources. Representatives of some 22 other programs and organizations were interviewed concerning their perceptions of the potential for transferring energy efficiency technologies through active linking with OBT.

Several key issues in transferring building energy technologies were identified:

1. Defining technology transfer clearly to include, for example, both scientific information exchange and activities that result in technologies actually being adopted and used

2. Deciding whether OBT should transfer technologies developed only by its own program or technologies developed by others (including foreign countries) as well

3. Identifying appropriate roles in technology transfer for the national laboratories

4. Identifying the research and analysis support needed for an integrated OBT technology transfer program 
5. Identifying the management support needed for effective technology transfer

6. Identifying the most effective means to link the OBT R\&D program with other programs and organizations within and beyond DOE to accomplish technology transfer.

OBT managers said they were particularly interested in obtaining evidence concerning the effectiveness of technology transfer strategies and mechanisms in achieving the actual use of energy efficiency technologies and practices in buildings.

\section{Program Overview}

In the past OBT emphasized three technology transfer strategies: (1) contracting R\&D to industrial partners, (2) influencing key intermediaries, and (3) working with broker organizations. Existing models suggest that through such techniques as segmenting user audiences and tailoring strategies to different stages of the technology development process, OBT can improve the effectiveness of its technology transfer program. The Office-wide program funds projects that are crosscutting in nature, benefit from standardized formatting, or have significant economies of scale.

The OBT R\&D program focuses on technologies, tools, and practices that will directly or indirectly result in decreased energy use in buildings. The program concentrates on only a few technologies, because the necessary research is time-consuming and expensive, and budgets are limited. These projects involve long-term, high-risk research that private enterprise cannot conduct. Thermally activated heat pumps and Stirling engines are examples of technologies requiring such long-term development. The transfer of this equipment, as it is developed, occurs with the involvement of a handful of product manufacturers. These technologies will not be ready for commercialization for some years. Nevertheless, early awareness and involvement on the part of entrepreneurs, venture capitalists, and manufacturers can hasten technologies' eventual production and marketing. The earlier that manufacturers are aware of and actively engaged in the research, development, and demonstration (RD\&D) process, the more quickly these types of technologies can be produced and commercialized. Most of the relevant technology transfer with respect to these $R \& D$ products occurs at the program and project level, not at the Office level.

The balance of the OBT program's activities--the shorter-term R\&D, software development, and other products--have broader audiences and require more assistance for transfer to be successfully accomplished. Three types of technologies, tools, and practices are (1) existing off-the-shelf technologies requiring no further federal assistance to commercialize, (2) existing off-the-shelf technologies requiring some additional federal assistance to hasten market saturation, and (3) those almost ready for transfer. To be effective in reaching the goal of reducing building energy use, OBT has to promulgate these products widely to a variety of audiences. Transfer of this technological information occurs both at the project and OBT-wide levels.

The OBT program has generated three successful technologies in recent years that appear to require no further assistance to reach full market acceptance. These are (1) low-e windows, (2) DOE-2, and (3) dielectric coatings. OBT has also generated five other technologies that are ready for use but appear to require some additional federal assistance to reach their full market potential. These are (1) solidstate ballasts for lighting, (2) unequal parallel compressor systems for supermarket refrigeration, (3) flame retention head oil bumers for home heating, (4) heat-pump water heaters for homes, and (5) radiant barriers used with attic insulation for homes in hot climates. OBT program managers, in a recent study, evaluated 42 tools, technologies, and practices that they defined as nearly ready for commercialization. Of these, 25 (or 60\%) were judged to require some federal assistance for successful diffusion. 


\section{Audiences}

Eight kinds of audiences for OBT tools, technologies, and practices based on functional roles were defined. These functional audiences are distributed across a wide variety of organizational types or structural audiences. For example, energy program implementers may be found at utility companies, small consulting firms, community action agencies, state energy offices, and national laboratories. These functional audiences form networks across structural audiences, or organizations, based on common needs for information. To reach functional audiences effectively, OBT needs to be sophisticated in its approach to its audiences through a variety of organizational conduits, using segmentation techniques to provide credible information through rusted channels.

\section{A Planning Framework}

Four central technology transfer functions were defined for Office-level technology transfer:

1. Transferring research results

2. Transferring new and existing OBT-developed technologies

3. Transferring non-OBT energy technologies

4. Increasing awareness of the OBT program.

Some part of the technology transfer resources that are available should be used for each of these functions. OBT management could vary the emphasis assigned to these functions over time; for example, an early push to increase program awareness could be slowly phased down as audiences became more aware of the OBT program. In contrast, transferring non-OBT technologies could be given increasing emphasis.

The Advisory Group developed a framework by creating a matrix using technology transfer functions as column heads and general functional target audiences as row heads. Two of these frameworks were produced by completing the cells of the matrix in two different ways: (1) identifying the organizational conduits (structural audiences) to reach each functional target audience, and (2) identifying activities to accomplish the function for the identified functional type of audience. For instance, using the framework on organizational conduits as a heuristic device, one cell of the matrix suggests that to promulgate OBT research results among federal buildings planners and managers, OBT could work with the National Institute of Standards and Technology (NIST), the Federal Energy Management Program (FEMP), the General Services Administration, the Department of Defense, and the Construction Engineering Research Laboratory.

About 60 examples of technology transfer activities were developed; these were suggested by program managers, group members, existing projects, and outside sources. Using the criteria developed, the group evaluated and ranked these activities; 20 of them emerged as the most important examples for OBT to consider in planning and funding its technology transfer program.

\section{Summary of Advisory Group Recommendations}

1. A technology transfer strategy that OBT could use effectively is to link its R\&D program with programs and organizations whose established missions involve disseminating energy efficiency information, implementing measures, regulating energy production and use, or representing relevant trades and professions. Based on a partial exploration of the opportunities for such linkages, the team concluded that OBT would find it particularly useful to pursue liaisons with FEMP, U.S. Department of Housing and Urban Development (HUD) programs, the National Association of Home Builders (NAHB), and NIST. Other significant opportunities for linkages exist with DOE's Office of Technical and Financial Assistance (OTFA), the National Appropriate Technology Assistance Service (NATAS), the National Association of Regulatory Utility Commissioners (NARUC), and the National Association of State Energy Officials (NASEO). OBT should continue to explore the potential for linking with other trade and professional 
organizations to develop a repertoire of working relationships that will affect technology transfer in a positive way.

2. OBT management should undertake a systematic, ongoing review of the Office's technology transfer activities. This process could be initiated with an intemal management review of technology transfer; convening technology transfer roundtables with extramural laboratory, government, and private-sector participation; and establishing a Technical Review Panel for Technology Transfer as a standing committee.

3. OBT should use seven criteria to assess candidate technology transfer activities. These criteria relate to

- Energy savings potential

- Cost-effectiveness in transferring technology

- Leveraging existing resources of other organizations

- Effectiveness in reaching unreached or underreached key audiences

- Congruence with OBT functions and strategy

- The use of innovative approaches

- The contribution to a balance across functions and audiences.

4. OBT should use the framework recommended as a heuristic device in planning its technology transfer activities. This framework can be used (1) to discem the specific structural audiences that will reach functional audiences and (2) to exhibit a way that already-funded and proposed activities can be evaluated against target audiences and technology transfer functions to test the program's balance.

5. The portion of OBT technology transfer dedicated to scientific information exchange appears to be working well in keeping buildings researchers informed about the program and its scientific progress. Standing and special-purpose review committees also appear to effectively involve the private sector with the program. These portions of the Office's technology transfer program should ...be preserved. Production of Buildings Energy Technology, Research in Progress and similar publications should be continued at about the same level of support.

6. OBT should engage at the Office-wide level in transferring new and existing OBT tools, technologies, and practices by working through product manufacturers and energy intermediaries-those actually producing, designing for, and implementing energy efficiency measures.

7. OBT should transfer new and existing tools, technologies, and practices developed by others, particularly through the Center for the Analysis and Dissemination of Demonstrated Energy Technologies (CADDET) and the Building Efficiency and Conservation Network (BEACON), if established. To fulfill its function of leading a national effort to increase the energy efficiency of the nation's buildings, OBT should include the transfer of any demonstrably workable technologies.

8. OBT should engage in activities to increase program awareness across the range of audiences potentially interested in the results of the R\&D program. These activities should enhance the probability of users' awareness and use of the program's R\&D results for scientific, educational, design, manufacture, construction, and other purposes to aid in increasing energy efficiency in buildings. Audiences would include public- and private-sector scientists, legislators, government officials, and consumers.

9. These four technology transfer functions--

- Research results

- New and existing OBT tools, technologies, and practices 
- New and existing non-OBT tools, technologies, and practices

- Program awareness

--should each receive some emphasis, and attention should be given to their relative importance over time.

10. Finally, OBT should engage in effective technology transfer activities that address each function. The example activities recommended as most important, not presented in rank order but organized by technology transfer function, are as follows.

\section{a. Research Results}

The portion of Office-wide technology transfer devoted to publishing bibliographies, research-in-progress reports, program overviews, and technology overviews should be continued at about the current level of effort. The use of standing and special-purpose committees should be preserved. The national laboratories should continue to be supported in promoting scientific information exchange through the normal scientific processes of conferences, peer review, and publication.

\section{b. Management and Research Support Activities}

1. Technology transfer handbook--presenting planning, procedures, resources, evaluation and significance of technology transfer in program effectiveness for OBT program managers, principal investigators at national laboratories, and other personnel.

2. OBT technology transfer roundtable(s)--assessing needs and sharing the technology transfer experiences of buildings industries and other users of OBT tools, technologies, and practices.

3. Technical Review Panel for Technology Transfer--establishing a standing committee of private-sector, public-sector, and laboratory representatives to review the technology transfer program.

4. Research on segmentation of OBT user audiences--characterizing the users of tools, technologies, and practices under development to permit information products and other activities to be tailored specifically for them.

5. Development of an evaluation design for technology ransfer programs--formulating a quasi-experimental design to permit systematic evaluations of existing federal information programs' effectiveness in transferring building energy technologies.

6. Evaluation of technology transfer effectiveness--using indicators such as requests for publications and software packages, numbers of copies sold, and the like.

7. Technology transfer in performance evaluations--rewarding OBT program managers for excellence in transferring technology through their programs.

8. Providing technical assistance and requiring a technology transfer plan as part of all R\&D projects--proactively planning and reviewing the technology transfer aspects of OBT programs at headquarters and in the laboratories.

9. Annual overall OBT technology transfer plan--developing a milestone schedule of technology transfer products and events for the entire OBT program. 
10. OBT Technology Transfer Award--displaying management's commitment to technology transfer through significant monetary and honorary awards for headquarters and laboratory staffs.

11. Electronic mail network for OBT and its national laboratories--enhancing communication between laboratories and headquarters staffs to facilitate the transfer of research results and program management.

\section{c. Transfer of OBT and non-OBT Tools, Technologies, and Practices}

1. Center for the Analysis and Dissemination of Demonstrated Energy Technologies (CADDET)--participating in international technology transfer with Intemational Energy Agency (IEA) countries to promote adoption by industry of successful energy efficiency technologies.

2. Trade magazine news releases and articles--sending news releases to various trade organizations and newspapers; assisting in the publication of more lengthy articles.

3. Building Efficiency and Conservation Network (BEACON)--providing credible and accessible performance information on building energy technologies to building practitioners and the general public through a normalized data base cooperatively administered through NIST, industry associations, utilities, and other concerned organizations.

4. Computer-based information systems for technology transfer--demonstrating to the building community efficient and innovative approaches for technology transfer using multimedia, such as CD-ROM, video memos, and information kiosks.

5. National laboratory host for ACSA Summer Institute on Energy and Environmental Systems--fostering understanding between architecture faculty and laboratory scientists on building energy technologies issues.

6. Curriculum materials for technical schools--initiating a program to improve the effectiveness of practitioner training in the buildings industries.

7. Implementing advanced building technologies by adopting architectural firms as information prokers--establishing a dialogue with architectural and engineering firms to form joint building technology application partnerships in the early phases of design commissions to foster research and communication of results to the building design community.

\section{d. Program Awareness}

1. Modular display of OBT research accomplishments--C/ Instructing a display on the OBT program to be used at trade shows for builders; reating, ventilation, and airconditioning (HVAC) contractors; and building materia : suppliers.

2. Information kiosk on the OBT program--constructing a I advanced-technology (such as a computer touch screen) information kiosk providing a hands-on exhibit to promote awareness of the OBT program at trade and prol essional association meetings and other shows and expositions.

These activities are described in more detail in the report. 
OBT management should expect technology transfer processes to take several years to achieve notable results in the marketplace. To support the efforts of its offices, the Department of Energy is developing a departmental technology transfer strategy. OBT should coordinate its efforts with those of OTFA and the DOE-wide strategy to enhance its technology transfer effort. Significant potential to reduce the energy consumed in U.S. buildings will be realized by accelerating the adoption of new and existing cost-effective technologies. 


\section{GLOSSARY}

\begin{tabular}{|c|c|}
\hline Abbreviation & Stands for \\
\hline ACEC & American Consulting Engineers Council \\
\hline ACSA & Association of Collegiate Schools of Architecture \\
\hline AGA & American Gas .Association \\
\hline AHAM & Association of Home Appliance Manufacturers \\
\hline AIA & American Institute of Architects \\
\hline ASEAM & A Simplified Energy Analysis Method \\
\hline ASHRAE & American Society of Heating, Refrigerating, and Air-Conditioning Engineers \\
\hline ASTM & American Society for Testing and Materials \\
\hline BCS & Office of Buildings and Community Systems (now OBT) \\
\hline BEAS & Building Energy Accounting System \\
\hline BECA & Building Energy-Use Compilation and Analysis \\
\hline BEP & Building Energy Programs \\
\hline BET & Building Energy Technolog: \\
\hline BTECC & Building Thermal Envelope Coordinating Council \\
\hline BTESM & Building Thermal Envelope Systems and Materials \\
\hline CADDET & Center for the Analysis and Dissemination of Demonstrated Energy Technologies \\
\hline CAREIRS & Conservation and Renewable Energy Inquiry and Referral Service \\
\hline CBT & Center for Building Technology (within NIST) \\
\hline CCB & Construction Criteria Base (within NIBS) \\
\hline CDBG & Community Development Block Grant \\
\hline $\mathrm{CE}$ & Office of Conservation and Renewable Energy (within DOE) \\
\hline CLPHA & Council of Large Public Housing Authorities \\
\hline DOC & Department of Commerce \\
\hline DOD & Department of Defense \\
\hline DOE & Department of Energy \\
\hline DSM & demand-side management \\
\hline EBER & Existing Buildings Efficiency Research \\
\hline ECPA & Energy Conservation and Production Act \\
\hline ECUT & Energy Conservation and Utilization Technology \\
\hline EEI & Edison Electric Institute \\
\hline EES & Energy Extension Service \\
\hline EPA & Environmental Protection Agency \\
\hline EPRI & Electric Power Research Institute \\
\hline ER & Energy Research \\
\hline ERIP & Energy Related Inventions Program \\
\hline ESCO & Energy service company \\
\hline EUR & Energy Utilization Research \\
\hline FEMP & Federal Energy Management Program \\
\hline FHA & Federal Housing Authority \\
\hline FLC & Federal Laboratory Consortium \\
\hline GNMA & Government National Mortgage Association \\
\hline GPO & Government Printing Office \\
\hline GRI & Gas Research Institute \\
\hline GSA & General Services Administration \\
\hline HBAs & Home Builder Associations \\
\hline HBI & Home Builders Institute \\
\hline HUD & Housing and Urban Development \\
\hline IAQ & Indoor air quality \\
\hline ICP & Institutional Conservation Program \\
\hline IEA & International Energy Agency \\
\hline IOU & investor-owned utility \\
\hline
\end{tabular}




$\begin{array}{ll}\text { IUPP } & \text { integrated utility planning processes } \\ \text { LBL } & \text { Lawrence Berkeley Laboratory } \\ \text { LCC } & \text { life-cycle costing } \\ \text { LCUP } & \text { Least-Cost Utility Planning } \\ \text { LIHEAP } & \text { Low-Income Home Energy Assistance Program } \\ \text { MIT } & \text { Massachusetts Institute of Technology } \\ \text { NAHB } & \text { National Association of Home Builders } \\ \text { NAHRO } & \text { National Association of Housing and Redevelopment Officials } \\ \text { NARUC } & \text { National Association of Regulatory Utility Commissioners } \\ \text { NASA } & \text { National Aeronautics and Space Administration } \\ \text { NASEO } & \text { National Association of State Energy Officials } \\ \text { NATAS } & \text { National Appropriate Technology Assistance Service } \\ \text { NCSBCS } & \text { National Conference of States on Building Codes and Standards } \\ \text { NESC } & \text { National Energy Service Council } \\ \text { NIBS } & \text { National Institute of Building Sciences } \\ \text { NIST } & \text { National Institute of Standards and Technology (within DOC) } \\ \text { NTIS } & \text { National Technical Information Service } \\ \text { OBT } & \text { Office of Building Technologies } \\ \text { OECD } & \text { Organization for Economic Cooperation and Development } \\ \text { OPA } & \text { Office of Public Affairs (within DOE) } \\ \text { ORNL } & \text { Oak Ridge National Laboratory } \\ \text { ORTA } & \text { Office of Research and Technical Applications } \\ \text { OSTI } & \text { Office of Scientific and Technical Information (at ORNL) } \\ \text { OTC } & \text { Office of Technology Commercialization (within NIST) } \\ \text { OTFA } & \text { Office of Technical and Financial Assistance } \\ \text { PHAs } & \text { Public Housing Authority } \\ \text { PUC } & \text { Public Utilities Commission } \\ \text { PVE } & \text { petroleum violation escrow } \\ \text { R\&D } & \text { research and development } \\ \text { RFP } & \text { request for proposals } \\ \text { SBIR } & \text { Small Business Innovation Research } \\ \text { SBSE } & \text { Society of Building Science Educators } \\ \text { SECP } & \text { State Energy Conservation Program } \\ \text { SEO } & \text { state energy office } \\ \text { SERI } & \text { Solar Energy Research Institute } \\ \text { STIP } & \text { Solar Technical Information Program } \\ \text { TIG } & \text { technical information guide } \\ \text { TIS } & \text { Technical Inquiry Service } \\ \text { VA } & \text { Veterans Administration } \\ \text { WAP } & \text { Weatherization Assistance Program } \\ & \end{array}$




\section{INTRODUCTION}

The mission of the Office of Building Technologies (OBT) is to lead a national effort to achieve the maximum, cost-effective energy productivity in the buildings sector. That such an effort will be part of our national energy strategy is virtually assured.

Secretary of Energy James Watkins initiated the process that will result in a National Energy Strategy (NES) to be submitted to the President of the United States in January 1991. J. Michael Davis, the Assistant Secretary for Conservation and Renewable Energy, has stated, "The importance of conservation and energy efficiency has been so often expressed and so obvious ... that an increased emphasis on these areas must clearly be a product of the National Energy Strategy" (Davis 1989).

For energy efficiency to contribute to the nation's energy goals, millions of diverse intermediaries and end users must decide to invest in and make use of it. Market availability and acceptance are pivotal to buildings energy efficiency contributing to the nation's energy "supply."

The NES process has highlighted the known benefits of energy efficiency in buildings, transportation, and industry. These include

- Saving fimite energy supplies

- Reducing the cost of energy services

- Improving national security

- Improving U.S. competitiveness

- Reducing acid rain

- Slowing global climate change

- Reducing ozone depletion (Millhone 1989).

These multiple benefits make energy efficiency an attractive option. Even where scientific uncertainty exists, energy efficiency makes sense on other grounds and is not detrimental to any primary national concern.

After the Oil Producing and Exporting Countries (OPEC) oil embargo in 1973, energy efficiency in U.S. buildings improved markedly. While the number of residences increased by $22 \%$, overall residential energy consumption increased only 4\% (Millhone 1989). Similarly, energy consumed in commercial buildings increased 24\%, while floor space increased 30\% (Millhone 1989). Nevertheless, efficiency gains have been reversed in the past 3 years, possibly as a result of to relatively low oil prices. Future increases in building energy use are expected, continuing a 20 -year trend of increasing electricity use.

The potential to conserve energy in existing buildings has been estimated at $25 \%$ with existing costeffective technologies in at least one analysis (U.S. DOE 1987). Even greater energy efficiency can be achieved in new buildings. Other analyses have produced similar results. One reason this potential has not been fully realized is the failure of consumers to invest in energy efficiency measures that perform effectively and pay back investments within at least 7 to 10 years, and often much sooner-within 1 to 2 years. The effective transfer of energy efficiency technologies for buildings is a critical task facing OBT and the nation if we are to realize the benefits of the nation's investment in energy efficiency research. 
This report presents the results of an interlaboratory planning effort to aid the U.S. Department of Energy's Office of Building Technologies in further improving its technology ransfer program. The program evolved from an effort in research utilization in the late 1970s and early 1980s to its current form as part of the former Office of Buildings and Community Systems Analysis and Technology Transfer (A\&TT) Program. The sections that follow present the planning task, planning issues, and approach taken. The planning effort's background is reviewed in the context of federal legislation and several recent national reviews of technology transfer at DOE, including the emerging National Energy Strategy. The existing technology transfer program is described--including the use of standing and special-purpose review committees--as are OBT program managers' views on that program. The technologies, tools, and practices being developed within OBT and an assessment of their readiness for commercialization are described briefly.

Audiences for OBT technology transfer are classified and described. Summaries are presented of the results of discussions with representatives of organizations with whom OBT might form links to transfer results of the $R \& D$ program. Decision processes and criteria that OBT management might employ to ensure ongoing review of its technology transfer activities by the private and public sectors are discussed. Finally, a framework is presented that OBT management could employ to identify appropriate organizations with whom to work and to select among technology transfer activities. 


\section{THE PLANNING TASK}

A strategic issue for OBT is improving the transfer of energy tools, technologies, and practices to the array of users needing them. The oft-cited fragmentation of the buildings industries as a barrier to successful technology transfer is being approached as a challenge to be met. In the context of its planning activities, the Office of Buildings and Community Systems gave technology transfer additional emphasis during FY 1989 and FY 1990. This technology transfer plan has been developed to define a framework OBT can use to move its technology transfer effort forward in the most effective manner, and in a way that fits overall program goals. The approaches defined in the plan can be "calibrated" with the National Energy Strategy technology transfer approaches.

\section{Approach}

The planning task began with the guiding assumption that OBT should increase its effectiveness in transferring buildings energy technologies by linking its programs with existing programs. Technology transfer at both the program and project levels are being addressed; however, the focus of the current effort is Office-wide technology transfer.

The approach taken to the planning task was to form an ad hoc interlaboratory Technology Transfer Advisory Group to review the current program, share information, brainstorm technology transfer approaches, identify applicable research results and a bibliography, and develop a framework that management could use in deciding on the best investments for technology transfer resources. The approach taken involved completing a detailed inventory and funding histories for recent and current technology transfer products, projects, events, and related analysis projects. Technology transfer planning issues were defined within the context of OBT strategic planning. Program managers were interviewed about technology transfer. Drawing on existing work, the Advisory Group identified technologies and products needing transfer, identified existing technology transfer ideas and initiatives, and developed potential new ones. Representatives of 22 other programs and organizations were interviewed conceming their perceptions of the potential for transferring energy efficiency technologies through active linking with OBT. The group developed a list of criteria that could be used to select activities. The group also systematized the opportunities for linkages with existing programs and developed a framework for deciding what organizational avenues might prove most fruitful to pursue. This framework can also be used to organize technology transfer activities so that they may be selected to fulfill different technology transfer missions.

\section{Planning Issues}

OBT faces several key issues in transferring energy efficiency technologies for buildings. The building industries are large and diverse. More than 50,000 home builders and 150,000 different companies are involved. Each new building receives products and services from more than 50 industrial sectors (Millhone 1989). Because of this fragmentation, the task of improving buildings energy efficiency is a daunting one that will require extensive cooperative private/public sector efforts to accomplish. It is, however, by no means impossible. The task's complexity is heightened by the diversity and number of the individual and organizational players involved. Because of the diversity of users, no single avenue of technology transfer could be expected to reach more than a few of them. This complexity suggests that intelligent planning and careful allocation of limited resources will be required for success.

\footnotetext{
*The Advisory Group included representatives from Oak Ridge National Laboratory, Pacific Northwest Laboratory, Lawrence Berkeley Laboratory, and the Solar Energy Research Institute. Throughout this document, it is frequently referred to as "the team" or "the group."
} 
A technology transfer strategy that appears sensible and effective is active interaction with existing government programs whose responsibilities affect energy use in buildings and with trade and professional associations whose members have similar responsibilities. OBT therefore needs to develop approaches such as segmentation analysis to underlie specific technology transfer activities. One approach would be to associate each technology or process to be disseminated with its user groups.

Furthermore, because OBT manages an R\&D program whose products, once employed, aid materially in solving pressing national concerns, a useful strategy for OBT will be to foster relationships with organizations dealing with these concerns. These organizations can play an important role in furthering energy efficiency goals, once they fully understand the possibilities and their potential role in realizing them.

Finally, in addition to working with existing programs and networks, OBT might wish to disseminate certain types of information directly to energy end users, such as homeowners, small businesses, and corporate decision makers. These people make the investment decisions that will ultimately affect the energy efficiency of the nation's building stock.

For OBT to have a systematic and defensible mode of selecting technology transfer activities, several issues need to be addressed. Some of these are

1. Defining technology transfer. Much of what is currently termed "technology transfer" involves conveying information about research results to other building scientists, rather than in transferring technology to intermediaries and energy users--those actually purchasing and using technological products. Annotated bibliographies, publication lists, mailing lists, and descriptions of R\&D programs are largely devoted to the exchange of scientific information among researchers. Since much of the existing OBT effort at research utilization can be categorized as scientific information exchange (which is perfectly appropriate for an R\&D program), the level of effort devoted to technology transfer is perceived by program managers and researchers to be higher than the level actually used to transfer technology to users, as distinct from researchers. Confusion about what the term "technology transfer" means seems widespread; clarity of purpose is needed.

2. Deciding which technologies to transfer. OBT management should determine whether to limit its technology transfer activities solely to technologies developed through its own programs, or to include buildings energy efficiency tools, technologies, and practices known to be effective in terms of cost and performance, regardless of where they were developed. This issue has been highlighted by DOE's participation in the technology transfer activities of the International Energy Agency's (IEA's) Center for the Analysis and Dissemination of Demonstrated Energy Technologies (CADDET). Information on energy technologies developed in member countries is being disseminated among the participating countries, with plans to expand to developing countries. Does expanding to include non-OBT technologies fit within OBT's mission of leading a national effort? Does transferring foreign technologies adversely affect the balance of trade, if other countries also transfer U.S. technologies? Should OBT expand its technology transfer effort to include technologies developed in the private sector?

3. Identifying appropriate laboratory roles in technology transfer. OBT program managers and principal investigators at national laboratories have estimated that $25 \%$ to $50 \%$ of their resources go to "technology transfer," a large proportion of which may be for the exchange of scientific information, as already noted. OBT needs to solve the problem of defining, identifying, and supporting technology transfer activities at the national laboratories and to provide technical support for those activities so that they can be successfully implemented.

4. Identifying research and analysis support needed for an integrated technology transfer program. Research on consumers' decisions and other analysis activities have not been coordinated with technology transfer activities to the extent that they should be nor used as the basis for designing these activities at either the programmatic or the project levels. Why? What 
can be done to remedy this situation? Is coordination desirable? Does more need to be known about the effectiveness of various technology transfer approaches? If so, what? How can linkages be achieved between the various laboratory staff working on analysis and technology transfer tasks so that coordination can occur?

5. Identifying management support needed for effective OBT technology transfer. Because program managers will continue to play a pivotal role in OBT technology transfer, what can be done to improve the effectiveness of their efforts and those of principal investigators? Should they receive technical assistance to support their efforts? Will they accept it? What mechanisms could be used to improve their performance in this area? Also, how can efforts at the program manager level be coordinated with the Office-level effort and simultaneously be consonant with Conservation and Renewable Energy (CE) and broader DOE efforts?

6. Identifying the most effective means for linking the program with other programs and organizations within and beyond DOE. The private sector has participated in several major OBT programmatic reviews, critical reviews of technology programs, and advisory boards for projects and technology programs. They have shared the costs of some R\&D projects. Should their participation be further encouraged? If so, why? What form should this encouragement take? How else might they be involved in technology transfer efforts? Should universities and the private sector have a greater role in A\&TT activities than in the past? For example, should the private sector or should national laboratories be maintaining mailing lists for DOE?

\section{Summary}

Transferring buildings energy efficiency technologies effectively is a seminal issue for the nation's R\&D program. Management decided that a planning task should explore ways that the Office could increase its effectiveness in transferring building energy technologies, given the context of fragmented buildings industries in the United States. A guiding assumption of the planning effort was that OBT, as an R\&D organization, should forge linkages with existing programs whose goals include enhancing energy efficiency in buildings.

An ad hoc interlaboratory Technology Transfer Advisory Group was formed to review the current program, share information, develop technology transfer activities, and recommend a process by which such activities could be evaluated. Frameworks that OBT management could use in deciding on the best investments of technology transfer resources were to be developed. Representatives of some 22 other programs and organizations were interviewed concerning their perceptions of the potential.for transferring energy efficiency technologies through active linking with OBT.

Several key issues in transferring buildings energy technologies were identified. These were (1) defining technology transfer clearly to include both scientific information exchange and activities that result in technologies actually being adopted and used; (2) deciding whether to transfer technologies developed only by OBT or technologies developed by others, including foreign countries, as well; (3) assigning appropriate roles in technology transfer to the national laboratories; (4) identifying research and analysis support needed for an integrated technology transfer program; (5) identifying management support needed for effective technology transfer; and (6) identifying the most effective means for linking the program with other programs and organizations within and beyond DOE. In addition, OBT management may wish to decide on whether to include energy consumers as an audience. This report deals with the Advisory Group's recommendations conceming these and other issues. 


\section{BACKGROUND AND CONTEXT}

Technology transfer is currently receiving more attention than it has for a decade. Major national reviews have highlighted the importance of technology transfer to the success of DOE's multiple missions. Challenges to effective technology transfer have been described, as has the federal response to those challenges. An NES review of technology transfer listed strategies and mechanisms as they have been described in recent literature. Finally, the problem of evaluating the effectiveness of technology transfer has also been discussed in recent literature.

\section{Barriers to Technology Transfer}

Technology transfer is difficult. Appreciation of this seems to be accumulating as DOE evaluates its decade-long experience with technology transfer. Formidable obstacles to effective technology transfer exist.

DOE (1989: 29-31) has defined three major categories of challenges to technology transfer: (1) conflicting policies, (2) legislative barriers, and (3) inadequate incentives and mechanisms. Cited as conflicting policies are the potential or actual conflict between a program's primary mission and its technology transfer mission. For example, managing uncertainties associated with the scientific discovery process while finding commercial opportunities for new discoveries can seem contradictory. Basic research requires open communication and publication of results, while commercialization encourages restricted access to information to ensure knowledge benefits to a particular company or industry. Achieving an appropriate balance between dual missions is problematic. Also, successive administrations have shifted emphases among energy programs, which has led to discontinuities in budgetary commitments. Similarly, national sentiment for a domestic preference policy could result in restricted access to $R \& D$ information and business opportunities in other countries.

Legislation that originally covered the Atomic Energy Commission and now covers DOE requires the dissemination of unclassified and nonsensitive scientific and technical information, and the Freedom of Information Act also provides that records must be disclosed (U.S. DOE 1989: 30). These provisions make it difficult to provide exclusive use of data to industrial partners, resulting in their reluctance to participate in joint ventures for fear of losing information to competitors after they have made significant investments in it. In addition, antitrust legislation may inhibit the formation of consortia for research, development, and demonstration (RD\&D) and production purposes, and conflict of interest legislation could interfere with personnel exchanges between govemment and industry. Statutory allocation of invention rights to individual organizations may inhibit equitable negotiations and agreements.

Other barriers also exist. DOE stated that "while energy prices are often cited as the primary reason for the unsuccessful transfer of a technology, there are many others that are equally potent" (U.S. DOE 1989: 31). Those listed were

- Inadequate market research on user needs and interest

- More competitive technologies brought to market

- Lack of user involvement in the development process

- Lack of a "champion" to lead the transfer process

- Potential market too small to support commercialization

- Lack of venture capital or other start-up funding

- Technology advantages too small to interest users

- Technology too complex for potential producers and users 
- Resistance to change (the "not-invented-here" syndrome)

- Cultural or subcultural differences between developers and recipients.

The Energy Research Advisory Board (ERAB) (1988: 44-45) defined the following barriers: building industries' fragmentation, lack of perceived relative advantage on the part of consumers, little industryfunded research to improve building methods or technologies, and severe competition from abroad.

Brown et al. (1986) identified six types of barriers to technology transfer: (1) programmatic, (2) legal, (3) institutional, (4) building industries' fragmentation, (5) information, and (6) market. Programmatic barriers exist as a result of insufficient funding for technology transfer and the subsequent lack of planning for it. Legal barriers include delays in adopting new building codes; design and product liability requirements; income tax depreciation, which encourages substandard buildings; short-term profit motives of building owners leading to investment decisions that omit energy efficiency; and federal patent policy, which prevented private companies from protecting their investment in product development from competitors. Institutional barriers defined included pass-through leases, master metering, poor building design from an energy efficiency standpoint, and emphasis on low initial building costs rather than on low operating costs.

Fragmentation was cited as inhibiting the flow of information within the building industries and interfering with industries' ability to conduct cooperative R\&D. Information barriers identified included the lack of time to read and evaluate the avalanche of relevant information, the lack of and limited distribution of bibliographies, the lack of a central clearinghouse for technical information on building technology, poor communication between the public and private sectors about research being performed, failure to incorporate $R \& D$ results into technical handbooks, and perceptions of risk associated with adopting innovative technologies. Market barriers included the perceived risk of purchasing innovative technological products, low perceived cost savings, and the perception that energy costs will not escalate in the future.

\section{Federal Response to the Problem}

The competitiveness of U.S. industry has been a national concern for some time. The problem is not one of creativity or inventiveness, because private entrepreneurs and inventors continue to produce a cornucopia of useful ideas and inventions. The problem, instead, appears to relate to the manufacturing capabilities of U.S. industry and the private sector's willingness to invest in longer term, rather than quarterly, profits.

Congress has been concerned about this issue for several years, and federal legislation enacted in the last decade has reflected this concern. Relevant to technology transfer, Congress enacted the StevensonWydler Technology Innovation Act of 1980 (P.L. 96-48) and the Federal Technology Transfer Act of 1986 (P.L. 99-502). These federal statutes recognize the problem that, although the nation was investing in scientific and technological R\&D, industry was slow in taking up the results of the national investment and translating them into profitable products and services, thereby creating jobs and strengthening the domestic economy.

These acts require that govemment agencies funding R\&D devote $0.5 \%$ of their R\&D budgets to technology transfer. Federal laboratories with at least $\$ 20$ million in R\&D funding are required to maintain at least one full-time staff person and allocate $0.5 \%$ of their budgets to technology transfer and to establish an Office of Research and Technology Applications (ORTA). 
The Federal Technology Transfer Act of 1986 requires that incentives be established, including royalty sharing and establishing technology transfer accomplishments, as performance evaluation criteria. The Federal Laboratory Consortium (FLC) was established, and aligned with the National Institute for Standards and Technology (NIST, formerly the National Bureau of Standards), to receive funds from a tax on federal agencies. The Act formalized the National Technical Information Service's (NTIS) role in licensing activities and disseminating technical information. Further, the statutes changed policy concerning intellectual property, such as patents, copyrights, and licensing, to improve the private sector's access to federally developed technologies (Brown 1988). The act permits government-operated laboratories to enter directly into cooperative agreements with industry and to license patents to costsharing sponsors of such agreements. It also requires that govemment employees and inventors share in royalties collected on patent licenses (U.S. DOE 1989: 15).

The Bayh-Dole Act (1980, amended 1984) originally allowed certain government contractors to retain title to government-funded inventions so that they could commercialize these inventions. The 1984 amendment allows national laboratories to retain title to inventions (U.S. DOE 1989: 15).

DOE issued a technology transfer policy order (Order 5800.1, Research and Development Technology Transfer Program) requiring the federal laboratories to conduct a variety of technology transfer activities, including patent licensing to the private sector. Each laboratory has flexibility in designing its own outreach program (U.S. DOE 1988e: 21). Since 1980, commercial rights to $40 \%$ of DOE patents have been waived or licensed to the private sector (Fitzpatrick 1988). In 1986, federal laboratories retained more than 162 patents.

The Energy Research Advisory Board consisted of 24 members from corporations, universities, research institutes, and national academies serving the DOE. In June 1984, former Secretary of Energy Donald Hodel requested that ERAB examine the future energy needs of the nation and develop judgments on the essential ingredients of a balanced energy R\&D effort, and provide general guidelines for the evolution of R\&D programs (ERAB 1985). ERAB recommended that

DOE should establish an advisory board of buildings experts to enhance technology transfer; the flow of relevant information to consumers should also be increased to improve rational consumer response (ERAB 1985: 12).

This was not, however, accomplished.

In February 1987, former Secretary of Energy John S. Herrington charged the Board to examine the prospects for practical energy $R \& D$ initiatives that might have significant impact within the next decade on the nation's economic competitiveness, and to consider those institutional barriers that would make it difficult to conduct such R\&D initiatives and implement their results (ERAB 1988b). ERAB identified the government role as improving information dissemination to consumers through equipment and building labeling, promoting the use of building codes and standards in government-used buildings, and developing a better understanding of how to transfer federal R\&D results to industry. ERAB (1988b: 44) recommended that DOE "aggressively pursue improvements in Federal energy end uses to demonstrate a firm commitment to improving U.S. energy competitiveness."

As part of his February 1987 charge, Secretary Herrington requested ERAB to evaluate the extent of industry use of DOE-supported R\&D and recommend improvements in the effectiveness of DOE technology transfer processes (ERAB 1988a). Among the major resulting ERAB recommendations were that DOE technology transfer policy should be strengthened; planning for technology transfer should be increased; the Secretary should initiate a program with industrial leaders to acquaint them with DOE's R\&D results; technology transfer components of research should receive additional funding; joint laboratory-industry research programs should be encouraged; and incentives and rewards should be created for successful transfer efforts (ERAB 1988a: 1-2). 
Thus, strong signals have been sent to DOE by its blue-ribbon advisory boards and by Congress to enhance its technology transfer activities and to increase their effectiveness in translating the results of R\&D programs into actual use. Careful planning and adequate resources are required to respond to the national need for improved technology transfer.

\section{National Energy Strategy Assessment of Technology Transfer}

Technology transfer is considered a major crosscutting issue for the National Energy Strategy, and documents are being prepared on it in connection with the current NES process (U.S. DOE 1989; Deonigi et al. 1989). DOE has defined technology transfer as

The process by which technology, knowledge, and information developed in one organization, in one area, or for one purpose is applied and used in another organization, in another area, or for another purpose (U.S. DOE 1989: 8; Deonigi et al. 1989: 1).

DOE has identified three generic types of technology transfer: (1) scientific knowledge transfer, (2) spin-off technology transfer, and (3) direct technology utilization. The first involves the normal process of scientific information exchange, such as publication and scientific meetings. The second, spin-off technology transfer, occurs when technologies are used in areas other than those for which they were developed. The third, direct technology utilization, occurs when technologies are used mostly for the purposes for which they were created.

DOE has stated that its technology transfer mission is to help move the results of R\&D programs into use, preferably by U.S. industry and for the benefit of U.S. citizens (U.S. DOE 1989: 3). Deonigi et al. (1989: 41) identified multiple goals for technology transfer, including introducing technology to the marketplace, transferring scientific knowledge, moving technology one more step in the development process, encouraging private-sector investment, obtaining feedback from users, improving the nation's technology base, enhancing user acceptance and use, and expanding spin-offs.

\section{Existing Technology Transfer Strategies and Mechanisms}

The former Office of Conservation used six strategies to transfer energy efficiency technologies for buildings, transportation, and industrial processes (Brown 1988). These were

- Contracting R\&D to industrial partners

- Working with industrial consortia

- Licensing to industry

- Influencing key decision makers

- Working with trade, professional, and regulatory organizations

- Generating end-user demand.

The former Office of Buildings and Community Systems emphasized contracting R\&D to industrial partners, influencing key intermediaries, and working with broker organizations, with secondary emphasis on generating end-user demand, according to Brown.

The transfer mechanisms used by Office of Conservation programs included the following (Brown et al. 1988; Brown 1989): 
- Workshops, seminars, conferences

- Technical assistance

- Peer exchanges (e.g., site visits)

- Cooperative R\&D projects

- Project review committees

- Information dissemination centers

- Mailings (newsletters, fact sheets)

- Technical reports

- News releases

- Articles in trade journals and magazines

- Broadcast media announcements

- Videotapes

- Decision tools (e.g., software)

- Electronic bulletin boards

- Codes and standards

- Data banks.

DOE (1989: 9-10) defined available technology transfer mechanisms as follows:

- Advisory groups

- Research collaboration

- Personnel exchanges

- Technical assistance

- Allocation of patent, copyright, or other intellectual property rights

- Spin-off companies

- Dissemination of information

- Education

- End-user incentives.

Deonigi et al. (1989: 10) defined a similar list of mechanisms, but it omitted end-user incentives and termed allocation of intellectual property rights as "licensing." The advantages and disadvantages of these mechanisms are described in Brown et al. (1988) and in Deonigi et al. (1989).

According to the DOE NES paper, these mechanisms can be used as part of strategies whose success depends on several variables, such as the specific technology transfer objective, the stage of development of the technology, the characteristics of the recipient, the form of the technology, the characteristics of the developer, and external factors such as financing and market conditions (U.S. DOE 1988e: 11-12). 


\section{Evaluating Technology Transfer}

Scanty empirical evidence exists conceming the efficacy of various technology transfer strategies and mechanisms. What evidence there is tends to be anecdotal and relies on case studies of successfully commercialized technologies (e.g., U.S. DOE 1988b). DOE has recently (1989: 24-27) reviewed the state of the art in evaluating technology transfer processes. The report identified two basic approaches to measuring technology transfer program performance: one can measure (1) the process itself, such as the number of technologies transferred, expenditures, or contacts, and (2) the actual results, such as the market share of a new product or measured energy savings resulting from the application of a new conservation technique. In general, it is easier and less expensive to measure the process than the actual results. DOE has collected information from its national laboratories concerning their technology transfer processes and results. Table 1 shows the summary data DOE presented (U.S. DOE 1989: 25).

Because the goals of technology transfer programs vary, they must be taken into account when evaluating the effectiveness of any given technology transfer effort (Deonigi et al. 1989: 7). Not all federally funded technologies have commercialization potential in the private sector. The nature and purpose of federally developed tools, technologies, and practices should be taken into account in evaluating how well transfer has been accomplished.

Table 1. National Laboratory Technology Transfer Processes and Results

\section{Process Measurements}

FTEs involved in technology transfer

Total technology transfer costs (\$K)

Users of DOE user facilities

Lab employees providing:

Outside consulting

State/local assistance

Contracts with industry, universities

Value of contracts (\$K)

Total reports, journal articles, papers

\section{Results Measurements}

Invention disclosures

Patent applications

Patents granted

Total licenses issued

Licensing royalties $(\$ \mathrm{~K})$

New companies formed

\section{FY 1988}

662

85,173

1,835

1,378

795

3,221

136,003

23,848

1,003

336

198

43

496

35

Source: U.S. Department of Energy (1989: 25).

\section{Technology Transfer Concepts, Models, and Processes}

Deonigi et al. (1989: 1-2) defined an idealized technology development sequence leading to commercial application of the new idea as follows: 
1. Basic research: discovering a new idea.

2. Exploratory research: determining the scientific applications of the new idea.

3. Applied research: determining the technical feasibility for a specific application.

4. Development research: developing and testing integrated systems.

5. Market penetration: demonstrating the technology and economic feasibility and redesigning it to market needs.

These stages are intended to represent a classical pathway from inception to the marketplace. Technology transfer is conceived as occurring between each stage of development as information is passed along from actors in one organization to those in another. At some point in the process, "ownership" of the idea is transferred to the private sector, where technology development continues. The transfer of ownership to private industry is enhanced by feedback processes between govemment and private-sector organizations on market conditions, availability of capital, and other factors that would affect successful commercialization. Mechanisms such as advisory groups provide such feedback to government $R \& D$ programs.

Deonigi et al. (1989: 43) suggested that technology transfer strategies be varied according to the stage of technological development. Figure 1 summarizes how such strategies might be used in connection with the developmental stages of an example technology.

Another way to conceptualize technology transfer is to consider both the technology development and the technology diffusion processes and how they might be overlapped to accelerate the adoption rate. In the diffusion-of-innovations research tradition, the user's decision process in adopting an innovation has been summarized as follows (Farhar and Unseld 1982):

1. Initial awareness

2. Knowledge-evaluation

3. Decision-intention

4. Action

5. Observation of effects

6. Continuance/discontinuance decision.

These stages apply whether the user is an individual, a household, an organization, or a community.

Using this approach, the question then becomes how to link the technology development process with the user process so that technology can be transferred most effectively. To the extent that the two processes can be overlapped, the time it takes to transfer information and ideas to the marketplace can be shortened. While end users would not become aware of new technologies or products until the market penetration stage, their decison processes would be accelerated because product manufacturers and intennediaries (infrastructure) would have already taken action to produce, distribute, install, inspect, and stand behind the products and technologies being promoted. This would short-circuit many of the problems innovators and early adopters have when they adopt innovations. For example, using the stages of technology development in Deonigi et al. and the technology diffusion stages developed in the diffusion-of-innovations research tradition, we can overlap the two, as shown in Figure 2.

DOE (1989: 11-12) has identified a number of variables that affect the success of a technology transfer program. In addition to the stage of technology development, the characteristics of the recipient, the form of technology, the characteristics of the developer and other factors can be critical to the outcome. 
Advisory Group

End-User Review

Technical Review

Collaboration

Contracting R\&D

Industry Consortia

Cooperative Research

Demonstration

User Facilities

Work for Others

Staff Consulting

Broker Groups

Staff Exchange

Guest Staff

Technical Assistance

Staff Transfers

Licensing

Spinoffs

Information

Workshops

Information Centers

Mailings

Technical Reports

News Releases

Joumals and Magazines

Fact Sheets

Video Tapes

Decision Tools

Electronic Boards

Education

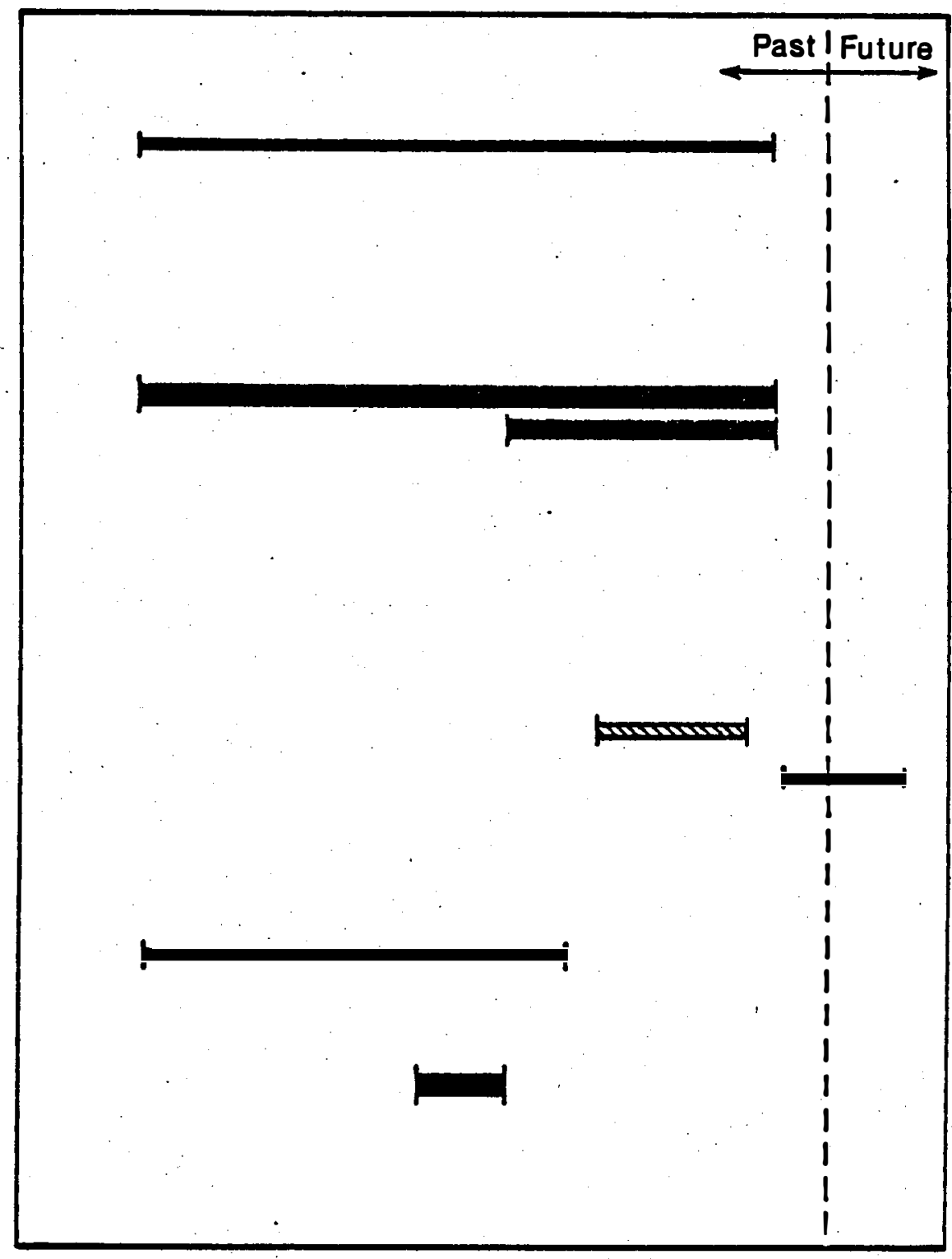

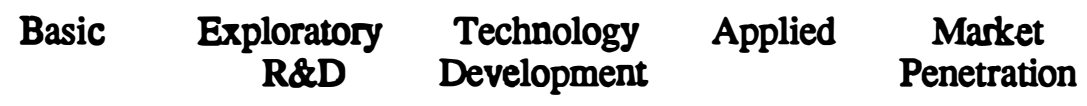

Stages of Technology Development

Key:

- Area of bar is proportional to the amount spent for the technology transfer mechanism.

- Shading [or size] of bar is an estimate of the technology transfer mechanism's effectiveness.

Very successful

Somewhat successful

Not very successful

Figure 1. Technology Transfer Strategy by Stage of Technology Development for One Example Technology (The Welding Laboratory at Idaho National Engineering Laboratory) [Adapted from Deonigi et al. (1989: 43)] 


\begin{tabular}{|c|c|c|}
\hline Technologist/researcher & $\begin{array}{l}\text { Product manufacturer } \\
\text { Intermedlary user. }\end{array}$ & End user \\
\hline Basic research & Initial awareness & \multirow[b]{5}{*}{$\begin{array}{c}\text { Initial } \\
\text { awareness }\end{array}$} \\
\hline Exploratory R\&D & Initial awareness & \\
\hline Technology development & Knowledge/evaluation & \\
\hline Applied research & Knowledge/evaluation & \\
\hline Market penetration & Action & \\
\hline \multirow{5}{*}{. } & Observation of effects & $\begin{array}{c}\text { Initial } \\
\text { awareness }\end{array}$ \\
\hline & $\begin{array}{l}\text { Continuance/ } \\
\text { discontinuance }\end{array}$ & $\begin{array}{l}\text { Knowledge/ } \\
\text { evaluation }\end{array}$ \\
\hline & & Action \\
\hline & & Observation \\
\hline & & $\begin{array}{l}\text { Continuance/ } \\
\text { discontinuance }\end{array}$ \\
\hline
\end{tabular}

Figure 2. Overlapping Stages in the Technology Development and Diffusion Processes

- Recipient characteristics thought to be important are

- Type of targeted user (industry, govemment, consumers)

- User maturity (start-up, growing, mature)

- User concentration (consolidated, fragmented)

- Financial and technical resources

- Culture (innovative, risk averse)

- How information is received (active, passive).

- Form of technology includes whether the technology is

- Scientific or technical knowledge/information

- Software

- Intellectual property (copyright/patent) license

- Process specifications

- Product design/specifications. 
- Developer characteristics considered relevant are

- Type (industry, government; university)

- Financial and marketing resources

- Culture (passive, aggressive).

- Other factors that can affect the success of technology transfer include

- $\quad$ Financing (venture capital, interest rates)

- Market conditions (energy prices, tax codes)

- Regulatory environment

- User incentives (tax credits, interest buy-downs)

- Market pull vs. technology push.

"Market pull" is defined as an indusiry or consumer need looking for a solution, such as lower energy costs or cleaner air (U.S. DOE 1989: 12). This unmet need creates a demand for technology solutions that "pulls" technological development. "Technology push" is defined as an improved product, process, or other technology seeking a market. Market-pull technologies are more readily funded by the private sector and adopted by end users. Technology-push technologies are funded primarily by govemment R\&D programs and require more resources to market.

These technology transfer concepts and models serve to illustrate the complexity of the technology transfer process and to underscore the difficulty of accomplishing technology transfer well.

\section{Summary}

Both DOE and the Congress have invested in improving the transfer of technologies. Difficult barriers to effective technology transfer have been identified, and Congress expressed its concem by passing federal legislation to encourage technology transfer. The Stevenson-Wydler Technology Innovation Act of 1980 and the Federal Technology Transfer Act of 1986 specifically require allocations from R\&D budgets to technology transfer functions. The statutues changed policy conceming intellectual property, such as patents, copyrights, and licensing, to improve the private sector's access to federally developed technologies. They established the Federal Laboratory Consortium and provided for government employees inventors to share in royalties collected on patent licenses.

DOE's Energy Research Advisory Board recommended greater emphasis on technology transfer to improve U.S. energy competitiveness. Technology transfer is being examined as part of the National Energy Strategy process currently under way. DOE has defined it as "the process by which technology, knowledge, and information developed in one organization, in one area, or for one purpose is applied and used in another organization, in another area, or for another purpose." In the past, the Office of Buildings and Community Systems emphasized three technology transfer strategies: (1) contracting R\&D to industrial partners, (2) influencing key intermediaries, and (3) working with broker organizations. Existing models suggest that through such techniques as segmenting user audiences and tailoring strategies to different stages of the technology development process, OBT can improve the effectiveness of its technology transfer program. 


\section{THE EXISTING TECHNOLOGY TRANSFER PROGRAM}

To provide a context for understanding the technology transfer planning task, an overview of the existing technology transfer program at the Office-wide level is presented. A great many more technology transfer activities occur within the research programs both at DOE, in the private sector, and at the national laboratories than are described here. While these activities comprise the majority of OBT's technology transfer efforts, they lie beyond the scope of the planning task. The Office regularly interacts with standing and special-purpose committees representing public- and private-sector interests. These committees, while providing program review, also served as Office-wide information dissemination channels. A brief overview of the committees is also provided. Relevant program managers were interviewed about the Office's technology transfer efforts; and their views are summarized.

\section{$\underline{\text { Overview }}$}

The bulk of technology transfer activity within the former Office of Buildings and Community Systems occurred in R\&D programs. These were organized into three divisions: Building Equipment, Building Systems, and Building Services. Division directors and program managers negotiated cost-shared projects with private industry; acted as brokers in product development partnerships involving venture capitalists, entrepreneurs, and large manufacturing concems; worked with program and project review committees; prepared technically reviewed fact sheets; served on committees of the American Society of Heating, Refrigerating, and Air-Conditioning Engineers (ASHRAE); and performed myriad other tasks to further the transfer of technology in as timely a manner as possible. Much of this activity has been performed in an ad hoc fashion at the discretion of program managers and principal investigators.

At the Office-wide level, technology transfer activities fell under the rubric of the Analysis and Technology Transfer (A\&TT) program, which was responsible for planning and analysis functions as well as for technology transfer. The program's 1987 annual report stated (Brookhaven National Laboratory 1988)

The BCS technology transfer program seeks to enhance the adoption and use of new technologies and research findings by developing and implementing a system to transfer R\&D results quickly, efficiently, and effectively to private- and public-sector users. The program supports technology transfer activities which will have a longterm positive impact on the design, construction, and maintenance of energy efficient buildings and community systems. The focus is on confidence in BCS products and persuasive arguments aimed at key intermediaries and building industry leaders.

About $\$ 500 \mathrm{~K}$ has beeen allocated annually to technology transfer activities and products, from an annual A\&TT budget approximating $\$ 2$ million. Technology transfer at the Office level, in contrast with the activities within the divisions, focuses on crosscutting activities that would not necessarily be supported at the division level.

Oak Ridge National Laboratory has led the OBT technology transfer program, and other DOE laboratories and subcontractors support it. Brown (1989) summarized the program as supplementing the technology transfer activities of program managers. The Office-wide program funded projects that (1) were crosscutting in nature, (2) benefited from standardized formatting, or (3) had significant economies of scale. Technology transfer projects generally fell into these categories (Brown 1989: 1):

- Needs assessments to determine future technology transfer directions

- University education and practitioner training

- Preparation of research and progress reports on R\&D efforts 
- Development and dissemination of design and decision tools

- Technical exchange, including conferences and workshops

- Support to program managers

- Evaluation and tracking of technology transfer activities.

In FY 1989, \$435K was spent on the following Office-wide technology transfer activities:

$\begin{array}{lrr}\text { Activity } & & \text { Amount } \\ & \underline{(\$ K)} & \underline{(\%)} \\ \text { Education and training } & \$ 129 & 30 \\ \text { CADDET } & 120 & 28 \\ \text { Faculty assignment to DOE } & 65 & 15 \\ \text { Publications } & 59 & 13 \\ \text { Management } & 40 & 9 \\ \text { Innovation case studies } & 22 & 5 \\ \quad \text { Total } & \$ 435 & 100 \%\end{array}$

Although the technology transfer program has been managed at ORNL, some support comes from other organizations. In FY 1989, the A\&TT budget was distributed among the following laboratories in this way:

\section{Organization \\ Oak Ridge National Laboratory \\ Lawrence Berkeley Laboratory \\ Pacific Northwest Laboratory \\ Brookhaven National Laboratory \\ Solar Energy Research Institute}

Total
FY 89

(\$K)

$\$ 550$ Technology transfer

380

340

240

160

$\$ 1,670$

\author{
Allocated to \\ Analysis \\ Planning support and analysis \\ Planning support \\ Planning support and \\ technology transfer
}

This was slightly less than the $\$ 1,815 \mathrm{~K}$ allocated to A\&TT in FY 1988 and the $\$ 1,713 \mathrm{~K}$ allocated in FY 1987. Certain technology transfer activities have been co-funded by outside organizations, including the National Institute of Architectural Education; the Electric Power Research Institute (EPRI); the American Consulting Engineers Council; and ASHRAE. Such co-funding is significant not only in stretching the resources available for technology transfer but also in ensuring the relevance of activities and products to user audiences.

Appendix A contains an annotated list of recent DOE building technology analysis and technology transfer organizations, products, events, reports, and projects. The annotations identify the audiences, show the funding levels, mention the organization responsible, and briefly describe the project. The appendix contains 53 entries, some for specific one-time projects and others for ongoing programs or periodical publications. A more detailed description of these activities may be found in the Analysis and Technology Transfer Annual Report (US DOE 1988a).

Analyzing the information on intended audiences for the projects listed in Appendix A, we find 13 different groups mentioned 74 times as audiences for A\&TT activities. Keeping in mind that these figures do not reflect the array of technology transfer activities within the Of fice and its national laboratories, we see in Table 2 the distribution of short- and long-term activities by intended audiences. 
Table 2. Distribution of A\&TT Activities by Intended Audiences

\begin{tabular}{lcc}
\hline & Percent & $\mathbf{N}$ \\
\cline { 2 - 3 } DOE/BCS program managers & & $(19)$ \\
Building researchers, analysts & 26 & $(13)$ \\
Architecture faculty, practitioners & 18 & $(10)$ \\
Energy service delivery organizations (utilities, & 14 & \\
$\quad$ state energy offices, energy service companies) & & $(8)$ \\
Mechanical engineering faculty, practitioners & 11 & $(7)$ \\
Intermediaries (e.g., builders, code officials) & 9 & $(4)$ \\
Product manufacturers & 5 & $(3)$ \\
Consumers & 4 & $(3)$ \\
Foreign countries & 4 & $(2)$ \\
Information intermediaries (media, trade press) & 3 & $(1)$ \\
Utility regulators & 1 & $(1)$ \\
Members of Congress & 1 & $(1)$ \\
& 1 & $(74)$ \\
\hline
\end{tabular}

The data show that the most frequently mentioned audiences for A\&TT activities are the buildings research community itself, including information for DOE officials and researchers at the national laboratories and elsewhere. The trade and professional group mentioned most frequently is architects. This distribution of A\&TT activities came about at least partly for historical reasons. Until only recently, for example, no one maintained a bibliography of Office-funded research products, documentation that is essential for program management as well as research purposes. Several information products, such as Buildings Energy Technology, Research in Progress, and Recent Publications of DOE's Office of Buildings and Community Systems were developed in the late 1980s to fill this need. The emphasis on architects, obviously important in terms of new building design, arose from the fact that the former Research Utilization Program was housed organizationally within the Building Systems Division, with its emphasis on whole-building integration and building design. Under its auspices, the Summer Institute on Energy and Design and the Institute on Energy and Engineering Education were first held in 1980. These institutes continued to be components of the A\&TT program after the research utilization function was renamed "technology transfer" and responsibility for it was moved to the Office level.

With the advent of an Office-wide technology transfer program in 1985, an effort was initiated to disseminate Buildings and Community Systems (BCS) R\&D findings through the building industry's trade press. This activity continued as a major thrust of the technology transfer program because of the role that trade magazines and associations play within the industry.

A second major initiative undertaken over the past several years was the development of publications describing the BCS R\&D programs. These publications have included

- Bibliographies of publications describing BCS-supported research

- Two-page overviews of individual BCS R\&D programs

- $\quad$ Longer overviews of the entire BCS R\&D program

- Compilations of BCS research in progress.

Appendix A describes these information products. 
The current planning effort has examined the relative emphasis placed on different kinds of intended audiences. The Technology Transfer Advisory Group has developed recommendations concerning the missions of OBT technology transfer, its intended audiences, and how the overall technology transfer effort might be better balanced across them.

\section{Standing and Special-Purpose Review Committees}

One of the ways that information about the OBT program has been promulgated is through the involvement of review committees (U.S. DOE 1988c). Private industry and national laboratories maintain approximately 65 standing and special-purpose committees that review the OBT program or specific projects within it. Some of these committees are

- Roofing, Waterproofing and Bituminous Materials Committee of the American Society of Testing and Materials (ASTM)

- Metal Building Advisory Panel Technical Committee on Fenestration (ASHRAE)

- Advisory Committee on Advanced Refrigeration Systems of the Air Conditioning and Refrigeration Institute

- Loose-fill Attic Insulation Acoustic Inspection Research Review Panel (within NIST)

- Lighting Roundtable of the Lighting Research Institute (LRI)

- Voluntary Residential Energy Standards Committee (ASHRAE).

These committees are maintained at division, program, and project levels, which has provided an ongoing technology transfer mechanism linking the Office with public- and private-sector experts.

\section{Program Manager Views}

During the summer of 1989, the Advisory Group team interviewed nine BCS division directors and program managers, focusing on four main questions:

1. What is your concept of technology transfer? How do you define it?

2. How do you distinguish technology transfer at your program level and at the Office-wide level?

3. Who specifically are the key audiences for your program?

4. What technical assistance or other help, if any, could the Office provide to your program concerning technology transfer?

A summary of the results of these interviews follows, dealing first with the common themes emerging from the interviews, and second with answers to each of the interview questions.

\section{Common Themes from the Interviews}

1. The program managers don't know what mechanisms are actually effective in transferring in technologies. Where, they ask, is the evidence?

Maybe we should survey the people we sent things to and see if they did anything with it, and set a break-up point--some success criteria, $10 \%$ or whatever. 
In other words, we need to evaluate this. Each approach is different but we have not carried the process far enough, and we need some evidence on this. Experts need to look at this.

In technology transfer, we need a survey of what is out there about the needs being met by the things that are being done. Which journals and magazines accept articles on energy conservation? Who makes the energy decisions? Do we need bibliographies?

Do we really want to spend significant amounts of money on a brochure that doesn't make much difference in stimulating the market?

These one- and two-page things, these program overviews and things on different technologies are not successful at all. Boxes of them are sitting there and they are not being used. There is no feedback on whether they are used.

2. The program managers say that networking, using existing networks and organizations, is essential.

You need to involve users when you conceptualize a product. The users are manufacturers and they are more involved, up front, in the whole process.

You need to force a big one- to two-day briefing and extend invitations to audiences to hear headquarters' presentation about what we are doing.

You need to get the industry people involved to cost share and provide in-kind services in the R\&D program. . . You need team building exercises to get input from different levels.

The AIA and the ACSA Research Council ... are talking about how energy is coming back. They ... . wanted to bring in eight to 10 key architects for a oneday workshop. They wanted to get them involved in making recommendations for the Building Systems program's research. AIA wants the research that can be commercialized and documents that practicing architects can use.

Technology transfer needs a spark plug--being proactive and reaching out to existing networks.

You need to involve industry in the R\&D and in the technology transfer parts.

3. OBT management has to emphasize technology transfer.

Leadership is key. . . People will follow the management leadership on this.

Program managers need guidance, but it needs to be given gently.

When you are a researcher, you are doing publications, and if you are doing research on technology transfer, you could do a technology transfer analysis of X, $Y$, and Z. These publications are kind of what counts as pushing people's careers. But if work behind the scenes for a means of transferring something ... it is an anonymous kind of effort. There are no kudos. It is a facilitating, broker kind of role. You cannot get promoted on that. It is a real problem and it won't result in career advancement. This is an institutional point--an institutional barrier to technology transfer. The person who does this is an unsung hero. 


\section{Responses to the Interview Questions}

1. What is your concept of technology transfer? How do you define it?

a. It occurs when behavior changes: someone is producing or using something they weren't before. This is distinguished from efforts to transfer technology.

b. Basically, it is getting information into the hands of implementing decision makers. For commercial buildings, for example, there are owners, procurement officers, managers, A\&Es, and contractors. There are both push and pull aspects of this.

c. It occurs only if the audience receives and uses the information, and we have evidence that they used it.

d. It means different things to different people--it's communication. You have to provide different products to different participating audiences, using the networks.

e. The traditional view was you develop technology, and then you transfer it. That's antiquated. Now, you get users involved earlier in the process, or you can't transfer it.

f. You need two steps: (1) translate R\&D results into some product in plain English, and (2) transform it again into something useful, like a tool, a set of recommendations, or a design tool. You need information products, whether BCS is doing the research or not.

g. Technology transfer occurs in four steps:

- $\quad$ Require of every project a final report;

- Out of this, give presentations to ASHRAE, ASTM, etc.;

- See that the information goes further downstream to target audiences;

- Provide information to the consumer--maybe.

2. How do you distinguish technology transfer at your program level and at the Office-wide level?

a. My impression is that it is a group of studies of the technology transfer process, not actually transferring technology. At the program level, we interact with industry at the grassroots level, to develop a specific tool. We also play the broker role with the researcher, the manufacturers and investors.

b. Historically, technology transfer activities moved from the division to the office level, such as the institutes; the demonstration programs were cut. Technology transfer is done ad hoc, at the individual investigator's whim. . . ASHRAE and others see that the material gets into the reference handbooks and manuals that engineers use.

c. Technology transfer used to be under research utilization with $\$ 1$ million funding, but the line item dwindled and the function was moved to the Office level.

d. The Office level deals with crosscutting audiences or technologies. The program level works on industry CEOs, trade associations, and with researchers in industry.

e. The Office should be dealing at the "megalevel," going past to crosscutting and higher-level issues (such as CADDET). Institutes should be at the division level. 
f. We need to coordinate information products and have them go through a screening test. We are sponsoring our own studies on technology transfer within our program.

3. Who specifically are the key audiences for your program?

The audiences defined by the program managers varied by division and program. Table 3 shows in detail the audiences they identified.

4. What technical assistance or other help, if any, could the Office provide to your program concerning technology transfer?

The program managers suggested 20 different ideas for technology transfer activities; these were included in the list of potential technology transfer activities evaluated by the Technology Transfer Advisory Group. Activities are described in Appendix E.

\section{Summary}

Although the Office made significant progress in its technology transfer efforts in the past decade, particularly given the relatively modest level of resources allocated to it, the Office's managers saw the need for a marked improvement in technology transfer to actualize the benefits to the nation from the buildings R\&D program. The portion of technology transfer dedicated to scientific information exchange appears to be working well in keeping buildings researchers informed about the program and its scientific progress. This portion of the Office's technology transfer program should be preserved. Managers were particularly interested in obtaining solid evidence about the effectiveness of technology transfer strategies and mechanisms in accomplishing the actual use of energy efficiency technologies and practices in buildings. 
Table 3. Functional Audiences by BCS Division*

\begin{tabular}{|c|c|c|c|}
\hline Audience & $\begin{array}{l}\text { Building } \\
\text { Equipment }\end{array}$ & $\begin{array}{l}\text { Building } \\
\text { Systems }\end{array}$ & $\begin{array}{l}\text { Building } \\
\text { Services }\end{array}$ \\
\hline Product manufacturers & $\mathbf{X}$ & $\mathbf{X}$ & \\
\hline $\begin{array}{l}\text { Utility companies and their associations } \\
\text { (EPRI, AGA, EEI, GRI) }\end{array}$ & $\mathbf{x}$ & & $\dot{x}$ \\
\hline Dealers/distributors & $\mathbf{X}$ & & $\mathbf{X}$ \\
\hline $\begin{array}{l}\text { Regulators and their agencies (EPA) and } \\
\text { associations (NARUC) }\end{array}$ & $\mathbf{x}$ & $\mathrm{X}$ & $\mathbf{X}$ \\
\hline Financial institutions & & $\mathbf{x}$ & \\
\hline Large investors & & $\mathrm{X}$ & \\
\hline Corporate and other building owners & $\mathbf{X}$ & $\mathbf{X}$ & \\
\hline $\begin{array}{l}\text { State and local code officials and their } \\
\text { associations (NCS) }\end{array}$ & & $\mathbf{X}$ & \\
\hline $\begin{array}{l}\text { Design professionals (A\&Es) and their } \\
\text { associations (AIA, ACSA) }\end{array}$ & & $\dot{x}$ & \\
\hline $\begin{array}{l}\text { Builders, contractors, and their } \\
\text { associations (NAHB, NIBS) }\end{array}$ & & $\mathbf{X}$ & \\
\hline ASHRAE committees & $\mathrm{X}$ & $\mathbf{x}$ & \\
\hline ASTM & $\mathbf{X}$ & $\mathrm{X}$ & \\
\hline BTECC & & $\mathrm{X}$ & \\
\hline Senior congressional staff & $\mathbf{X}$ & $\mathrm{X}$ & \\
\hline Building researchers & $\mathrm{X}$ & $\mathrm{X}$ & $\mathrm{X}$ \\
\hline ESCOs & & & $\mathrm{X}$ \\
\hline
\end{tabular}

*Consult the glossary for definitions of acronyms and abbreviations. 


\section{WHAT NEEDS TO BE TRANSFERRED? TECHNOLOGIES, TOOLS, AND PRACTICES}

To understand the problems facing OBT in transferring energy efficiency technologies for buildings, the technologies themselves need to be identified. A number of energy efficiency practices and measures have been accepted for several years as effective means of conserving buildings energy use. These include such practices as

- Heating and cooling system adjustments

- Hot water adjustments

- Plugging and sealing leaks

- Use of shades, curtains, and drapes

- Reducing energy use when space is unoccupied.

Commonly accepted measures include

- Caulking and weatherstripping

- Insulating ceilings, attics, walls, floors, water heaters, ducts, and pipes

- Energy-saving windows or doors

- Setback thermostats

- Electric load management devices

- Energy efficient furnaces, boilers, and heat pumps

- Replacement oil burners

- Vent dampers

- Electric ignition systems

- Energy-efficient air conditioners.

These types of practices and measures are usually included in utility company audit program recommendations and in basic weatherization programs.

The OBT R\&D program concentrates on only a few technologies because this kind of research is timeconsuming and expensive. The projects involve long-term, high-risk research that private enterprise cannot conduct. Development of such technologies as thernally activated heat pumps (TAHPs) or Stirling engines are examples of such long-term processes. The transfer of this equipment, as it is developed, occurs with the involvement of a handful of product manufacturers. These technologies are not currently or even nearly ready for commercialization. Nevertheless, early awareness and involvement on the part of entrepreneurs, venture capitalists, and manufacturers can hasten the eventual production and marketing of these technologies that will be available over the longer term. The earlier these manufacturers are aware of and actively engaged in the RD\&D process, the more quickly these types of technologies can be produced and commercialized. Most of the relevant technology transfer with respect to these $R \& D$ products occurs at the program and project level, not the Office level.

The balance of the OBT program's activities--the shorter-term R\&D, software development, and other products--has broader audiences and requires more assistance for transfer to be successfully accomplished. Three types of technologies, tools, and practices are (1) existing off-the-shelf technologies requiring no further assistance to commercialize, (2) existing off-the-shelf technologies requiring some additional federal assistance to hasten market saturation, and (3) technologies, tools, and practices 
additional federal assistance to hasten market saturation, and (3) technologies, tools, and practices almost ready for transfer.

\section{Existing Off-the-Shelf Technologies}

As DOE has performed R\&D on more energy efficiency technologies, a number of them have reached the market and appear to require no further federal assistance to reach market saturation. These include the following:

- Low-e windows: windows manufactured with a layer of coated film that transmits most of the sun's light while providing insulating value.

- DOE-2: a computer program that simulates building energy performance, used by building professionals to design and operate more efficient buildings.

- Dielectric coatings: a silver, aluminum, or other metallic coating for lighting fixtures that enhances the reflectivity of the light and decreases costs up to $40 \%$.

Table B-1 in Appendix B summarizes information on these successful technologies.

Another category of off-the-shelf technologies includes those that are currently on the market but still seem to require some additional federal assistance to successfully reach market saturation. These include the following:

- Solid-state ballasts for lighting

- Unequal parallel compressor system for supermarket refrigeration

- Flame retention head oil bumer for home heating

- Heat pump water heater for homes

- Radiant barriers used with attic insulation for homes in the South.

Table B-2 in Appendix B summarizes information on each of these technologies. Brown, Berry, and Goel (1989) analyzed their development and suggested some specific actions that could speed up the adoption process. For example, the high initial cost of solid-state ballasts is still a barrier. The commercialization of solid-state ballasts would be accelerated by (1) developing a complete lighting system that weighs less and is less expensive; (2) including them in utility demand-side management programs for commercial and industrial customers; (3) informing energy managers about them; and (4) advertising them in trade publications.

For unequal parallel compressor systems, servicing remains a problem. Personnel are untrained and reluctant to overhaul systems, which require more care than the ones they replace. Supermarkets prefer to do their own maintenance, but manufacturers train their own service personnel; thus, no overlap in interest exists. Also, energy constitutes only 3\% of supermarket total operating costs, and this, coupled with low profit margins, leads to a low incentive to adopt. Actions to solve these problems would help accelerate the adoption process.

For the flame retention head oil burner, the technology could be applicable as an energy efficiency measure in commercial and industrial oil-fired boilers and fumaces. These markets should be explored.

For heat-pump water heaters (HPWHs), high initial cost is a barrier to adoption: $\$ 800-\$ 1200$ with a 2- to 3-year payback, compared with $\$ 300-\$ 500$ for an electric resistance water heater. Heat-pump water heaters may not be suitable for northern climates because of their space-cooling effect. In general, consumers have not heard of this product. Also, energy use for water heating has low 
visibility--the lack of disaggregated information on electricity use keeps consumers unaware of it. In addition, plumbers and heating, ventilation, and air-conditioning (HVAC) service personnel are inadequately trained. Subdivision developers could install HPWHs in large lots, thus achieving some economies of scale and encouraging the development of local expertise in maintenance and replacement.

For radiant barriers, continued DOE support is needed to determine their appropriate role in cold and moist climates. The development of price and performance guidelines could also support proper marketing of the technology.

\section{Technologies Almost Ready for Transfer}

In a recent study of building technologies, Weijo, Nicholls, and Anderson (1988) asked DOE program managers to estimate how close to being marketable the tools, technologies, and practices being developed under their management were. In addition, the program managers were asked whether or not they thought the technologies needed assistance to be marketed successfully. This study specifically excluded the long-term R\&D projects mentioned earlier.

The box on the next page contains a list of the 25 tools, technologies, and practices defined as virtually ready for use and requiring some federal assistance to transfer. However, only one of the 25 constituted an actual energy-saving practice--tree planting (urban heat islands). The balance of the activities were analytical tools, methods, and processes. (Table B-3 in Appendix B summarizes information about the 25 items.) Another 17 items were assessed as not needing federal assistance for transfer.

Table B-4 in Appendix B lists 18 tools; technologies, and practices that the program managers assessed as not requiring any federal assistance for transfer. The report gave no reasons for this assessment. Of the 18, six are actual energy-saving technologies and the remaining 12 are analytical tools and methods.

\section{Summary}

The OBT R\&D program concentrates on technologies, tools, and practices that will directly or indirectly result in a decrease in energy use in buildings. One part of the program focuses on equipment or hardware, such as heat pumps, that is resource-intensive to develop. This technology is ordinarily transferred through collaborative RD\&D approaches with the private sector, especially product manufacturers, entrepreneurs, and investors. Another part of the program focuses on shorter-term analytical tools, software programs, information products, measurement tools, and practices, the results of which serve to decrease energy use in buildings through their application and use by building professionals. To be effective in reaching the goal of ultimately reducing energy use, these OBT products must be promulgated widely to a variety of audiences. Transfer of this technological information occurs both at the project and the Office levels.

The program has generated three successful technologies in recent years that appear to require no further assistance to reach full market acceptance. These are (a) low-e windows, (b) DOE-2, and (c) dielectric coatings. The Office has also generated five other technologies that are ready to use but appear to require some additional federal assistance to reach their full market potential. These are (a) solid-state ballasts for lighting, (b) unequal parallel compressor systems for supermarket refrigeration, (c) flame retention head oil bumers for home heating, (d) heat-pump water heaters for homes, and (e) radiant barriers used with attic insulation for homes in hot climates. In a recent study, OBT program managers evaluated 42 tools, technologies, and practices that they defined as nearly ready for commercialization. Of these, 25 (or $60 \%$ ) were judged to require some federal assistance for successful diffusion. 
Tools, Technologles and Practlces Almost Ready for Transfer

Urban heat islands

Integrated utility planning processes

Utility analytical tools

Solid fuel appliance measurement methods

Shared savings

Diagnostic protocols and analysis methods

Corrosiveness of Insulation

Maintenance and upgrade of DOE-2

Perfluorocarbon tracer system

Commercial standards

Roof Research Center

Simplified thermal analysis of roofs

Large-scale climate simulator

Roof thermal research apparatus

Superlite

Multifamily audit handbook

Diagnostic tool development

Radiant barrier modeling

Loose fill attic insulation settling

Acoustic testing of attic insulation

Moisture guidelines for residences

Core commercial daylighting

Energy tracking system

Thermal bridges design catalog

Advanced residential ventilation systems 


\section{TO WHOM ARE ENERGY EFFICIENCY TECHNOLOGIES FOR BUILDINGS TRANSFERRED?}

The nation's energy efficiency R\&D program for buildings, as managed by OBT, has numerous potential audiences. In some respects, as Pogo once sagely noted, "We are surrounded by insurmountable opportunities." Understanding the audiences for OBT research requires a thorough knowledge of how buildings are designed, constructed, and operated, and by whom, and with what organizational affiliations. The peripheral analyses, total development, and other activities pertinent to buildings and energy also need to be factored into the larger picture. To describe this as complex serves as an understatement.

To help clarify the picture, audiences can be classified into two general types: functional and structural. Functional audiences are those in the building community disaggregated by the functional roles they play. For example, building researchers have concerns about the development and dissemination of scientific knowledge that are distinct from, say, product manufacturer responsibilities for organizing production effectively. Structural audiences, on the other hand, are the types of organizations through which tasks are performed; e.g., buildings research is performed in universities, national laboratories, state energy offices, corporations, private research firms, and other organizations. In segmenting audiences, it will be useful to distinguish functional and structural attributes of audiences in assessing technology transfer activities designed to reach them.

In this section, eight functional audiences for are identified and described briefly. Next, some opportunities are described for OBT to link with specific structural audiences as a strategy for furthering the transfer of technologies in tandem with other organizations. Finally, the recommendations of the Technology Transfer Advisory Group are discussed that deal with pursuing linkages with other DOE and non-DOE programs.

\section{Key Functional Audiences}

Markets for products and audiences for information must be segmented if they are to be reached effectively. The audiences for the OBT program need to be segmented so that particular kinds of technology transfer activities can be designed specifically to meet their needs.

For the purposes of this discussion, audiences were classified into eight categories based largely on the types of functions these audiences perform with respect to energy use in buildings. These eight categories are
1. Building researchers
2. Product manufacturers
3. Energy intermediaries
4. Energy service deliverers
5. Federal programs
6. Information intermediaries
7. Communities
8. Energy end users.

A brief sketch of each of these audiences follows.

1. Building researchers. Across the nation, in federal, state and local government agencies, laboratories, corporations, and small firms, thousands of personnel make their living doing research in some way related to buildings. Although the roles, functions, and organizational affiliations of these personnel vary, they have in common the need to access the latest research results in the field in a timely way. They could be OBT program managers themselves, national laboratory researchers, researchers in consulting firms, in corporations, small business innovators, and entrepreneurs. Librarians and other information specialists supporting the research community also fall into this category. 
2. Product manufacturers. Manufacturers of products evolving from federally supported R\&D have a potentially significant interest in the R\&D program. They themselves cannot usually perform the basic research needed to undergird product development. Furthernore, their investment in product development and market research can outpace the government's investment by a factor of $80: 1$. Recent policies permitting the transfer of intellectual property rights to private concerns gives the manufacturers an incentive to be involved, thus helping to make them more attentive audiences. The kinds of companies germane to the OBT program include manufacturers of

- Wịndows

- Films, coatings

- Lighting, ballasts

- HVAC equipment, including heat pumps and desiccants

- Appliance manufacturers, including compact vacuum insulation

- Manufactured housing and components

- Building materials, including roofing, bricks, insulation, concrete and other materials.

Distributors and dealers are part of the manufacturing-to-market chain. They are trained by manufacturers in new products being developed and marketed, to the extent that any distributor or dealer training occurs. Because the availability of new products, along with the manufacturer's willingness to install, service, and warranty them, affects customer willingness to purchase, distributors and dealers are a critical link in transferring new technological products.

One efficient way that OBT can establish better relations with product manufacturers is to ask them to serve on program and project review committees. Another effective method is for OBT to work through existing trade associations representing the industries of interest. For example, in roofing alone, 10 different organizations represent relevant domains of expertise. By focusing on trade associations, OBT might help them achieve their goals of informing members, while reaching more firms with useful information. A third strategy for working with manufacturers is through cost-shared joint projects on specific technological research questions. Such efforts are beyond the scope of this report, which focuses primarily on crosscutting activities.

3. Energy intermediaries. Intermediaries make decisions that affect how energy is used in buildings without ever paying the energy operating costs in those buildings. Intermediaries, and their trade and professional organizations, are a critical audience to and through which energy-efficient tools, technologies, designs, and practices must be transferred if they are to have a positive effect on the nation's building stock. Energy intermediaries include

- Architects and engineers

- Builders

- Building managers

- Building owners

- Code officials

- Designers

- Insurance companies

- Lenders

- Materials and equipment dealers, distributors, and supply houses

- Realtors 
- Rehab/remodelers

- Standard-setting organizations (e.g., ASHRAE)

- Venture capitalists

- Utility regulators.

Numerous trade and professional associations represent these groups, including such organizations as the American Institute of Architects (AIA), the National Association of Home Builders (NAHB), the National Institute of Building Sciences (NIBS), and the National Association of Regulated Utility Commissioners (NARUC). OBT can communicate effectively with energy intermediaries at least in part by working through their associations.

Another pathway is through state and local programs and utility programs, many of which have unique efforts tailored for builders or code officials, for example.

4. Energy service deliverers. These organizations deliver energy services, including fuels and electricity, and energy efficiency programs to intermediaries and end users. The types of organizations that fall into this category include

- Utilities

- Private-sector energy service companies (ESCOs)

- Local energy offices

- Community action agencies delivering weatherization services

- Networking organizations (United Way, Nonprofit Energy Conservation Project, Interfaith Coalition on Energy)

- Quangos (quasi-autonomous nongovemmental organizations, such as the North Carolina Altemative Energy Corporation)

- State energy offices.

These service delivery organizations can intervene in the process between the development of new technologies and practices and their adoption and implementation. Because of their pivotal role as program deliverers, they are a key audience for OBT efforts. Besides the industry and professional organization representing these groups, DOE federal programs are vehicles through which energy service deliverers can be reached.

5. Federal programs. As mentioned, DOE programs are an important information conduit. These include the Weatherization Assistance Program (WAP), the Institutional Conservation Program (ICP), the Energy Extension Service (EES), and the State Energy Conservation Program (SECP). In addition, the federal govemment has direct and indirect responsibilities conceming energy use in federally owned and federally subsidized buildings. The Federal Energy Management Program (FEMP), for example, has a mandate to engage in programs to improve the energy efficiency of federal buildings, $80 \%$ of which are military buildings. The U.S. Department of Housing and Urban Development (HUD) administers public housing, guaranteed mortgage, loan, subsidized housing, and other programs that affect millions of housing units and involve billions of dollars. These programs have the potential to leverage improvements in energy efficiency in the buildings served. These federal government programs, due to their extensive domains of responsibility, are promising as significant avenues through which energy efficiency tools, technologies, and practices can be transferred. Through these programs, a variety of building researchers, energy intermediaries, and (ultimately) consumers can be reached. In the case of federal programs, since 
taxpayers are footing the energy bill, they can be the beneficiaries of decreased operating costs and subsidies for energy bills.

6. Information intermediaries. Primarily an R\&D program, OBT must rely on information specialists to translate research findings and the results of technology development into languages and formats tailored for specific user audiences, such as energy internediaries and consumers. Information specialists are located in a variety of organizations, including the national laboratories, the Office of Scientific and Technical Information (OSTI) located at Oak Ridge National Laboratory, and the National Technical Information Service (NTIS).

In addition, DOE funds specific information programs:

- The Conservation and Renewable Energy Inquiry and Referral Service (CAREIRS), designed to produce and provide fact sheets for the general public, including teachers and students

- The National Appropriate Technology Assistance Service (NATAS), designed to provide tailored responses for energy intermediaries and energy service providers

- The Solar Technical Information Program (STIP), designed primarily to produce and provide information products for renewable energy technologies for energy intermediaries and energy service providers

- The Federal Laboratory Consortium (FLC), designed to serve as a clearinghouse of information on a variety of topics about where scientific expertise is located within the federal laboratory system.

In addition, DOE's Office of Public Affairs (OPA) issues media releases, schedules press conferences, sponsors exhibits, and develops other public infornation programs.

OBT can use these existing information intermediaries to disseminate information about its program and itself to other key audiences.

7. Communities. Part of the OBT program is concerned with district heating and cooling. Another part of the program deals with building standards and codes, which are administered by state and local code officials. Communities and the organizations representing them, such as the Urban Consortium and the U.S. Conference of Mayors, can be key audiences for these OBT activities. This would be more the case at the project level than at the Office-wide level.

8. Energy end users. The end users use energy and pay the cost of energy use in buildings. They include homeowners, tenants of apartment units, small commercial enterprises that own or rent their buildings, and large corporate building owners. Some argue that OBT should approach consumers directly and educate them to demand specific technological products, such as heatpump water heaters, solid state ballasts, or low-e windows from builders, HVAC companies, home improvement centers, and other dealers. This approach stems from the idea that a market pull can be developed by creating a demand for energy-efficient products by generic (if not brand name) advertising. This idea appears to have gained currency at least in part by builders' and realtors' assertions that customers are not demanding energy-efficient housing, so they have nothing to gain by providing it. Since builders are concerned with initial costs and must compete for a market share, they have a disincentive to include energy-efficient features in their housing. Marketing studies indeed provide some evidence that energy efficiency ranks below other factors in housing purchase decisions.

Others argue that the problem is not the lack of consumer interest, but rather the failure of the infrastructures to provide the products and the personnel to install, service, and stand behind energy efficiency products. Numerous studies, including one by ORNL on energy-efficient replacement furnace purchasers, show widespread consumer willingness to spend more initially to obtain energy- 
efficient furnaces. But customers were dissuaded from doing so by their HVAC dealers, who were unfamiliar with these furmaces.

Given the current state of knowledge, it is impossible to determine whether the market-pull or the technology-push hypothesis is more important. Nevertheless, since OBT is an R\&D program, it probably cannot itself effectively mount or even sponsor a consumer education effort, and other programs have the mandate to perform that function in any event (such as OPA, CAREIRS, and EES). If these programs were advertised more, their inquiry rates would increase, and they would require more funding to meet demand. The issue remains how far OBT should go to inform energy end users about energy efficiency technologies.

\section{Program Networks and Linkages: Potential and Actual}

OBT may wish to use existing networks and infrastructures whenever possible to transfer energy efficiency technologies for buildings. The advantages of relying on existing networks are numerous. These networks have mechanisms in place for reaching audiences interested in energy efficiency technologies in buildings. Because staff in trade and professional organizations and in state and local programs are responsible for brokering information for their members or client organizations, they are open to opportunities to improve their performance in information transfer. By cooperating with other programs, OBT, as an entity with primarily R\&D functions, is spared the necessity of developing an extensive technology transfer program of its own, and thus "reinventing the wheel." Instead, OBT can maximize its investment in technology transfer by relying extensively on programs and networks already in place. OBT can work carefully with staff in other organizations to support and facilitate their efforts at information transfer and getting energy efficiency tools and technologies into actual use. Each organization in such arrangements stands to benefit by being better able to meet its goals. Thus, the relationships envisioned are not simply client-contractor ones, but rather ones in which each organization brings resources to bear to meet common goals.

Others have also called for increased cooperation between OBT and other programs. For example, Hirst (1989) called for improved coordination between DOE R\&D programs and state and local programs. DOE programs

represent potentially valuable mechanisms to implement new technologies and analytical procedures developed by DOE R\&D programs (Hirst 1989: 33).

Expanded funding for OBT could be used to increase the energy efficiency of federally assisted public housing and of homes served by WAP, Hirst said.

Forging such linkages may, therefore, be a key future OBT approach to technology transfer. Consequently, representatives of some 22 programs and organizations were contacted and face-to-face conversations were held to explore what the potential might be for transferring technology by linking with OBT. The informal discussions focused on identifying opportunities for linkage to transfer buildings energy efficiency technologies, and on identifying any problems that might be involved.

The results reflect the perspectives of persons in the programs with which OBT might forge linkages. The problems identified are of two types: (1) the organization's unmet needs for information that OBT could provide, and (2) possible barriers to forming productive linkages. The opportunities are defined from the standpoint of the other organization, not from the Technology Transfer Advisory Group's or OBT management's point of view.

The detailed briefs presented in Appendix $\mathbf{C}$ were derived from the interviews, the newly published Directory of Energy Efficiency Information Services for the Residential and Commercial Sectors, and other sources provided by respondents. Each brief was sent to the respondents contacted for their review and comment one or more times, and each was revised to reflect those review comments. 
The briefs in Appendix C identify the organization and relevant programs; provide the contact person's name and contact information; defme the audience(s); mention the relevant funding levels or organizational size, when this was not considered sensitive; describe the programs briefly; and list barriers to and opportunities for OBT linkages.

The organizations included for review may be classified as

- DOE programs

- Existing information services

- Other federal programs (non-DOE)

- Trade and professional organizations.

The organizations were selected for attention on two bases:

1. Management specifically identified certain programs as being of particular interest.

2. The ad hoc Technology Transfer Advisory Group requested more information about certain programs.

The list of organizations and programs interviewed is in no sense intended to be exhaustive. Instead, it represents a preliminary effort to identify potentially significant near-term opportunities to enhance energy efficiency in buildings through effective technology transfer. Many other organizations are equally or even more worthy of attention and of being included in OBT efforts to transfer technology through existing programs. Since this was a planning effort, it was not possible to include every possible organization. In the future, however, OBT may well expand its efforts to interact with existing networks.

The organizations included in the current effort are as follows:

DOE Programs:

Energy Extension Service (EES)

State Energy Conservation Program (SECP)

Institutional Conservation Program (ICP)

Weatherization Assistance Program (WAP)

Energy Related Inventions Program (ERIP)

Federal Energy Management Program (FEMP)

Small Business Innovation Research (SBIR)

\section{Federal Information Services:}

Conservation and Renewable Energy Inquiry and Referral Service (CAREIRS)

National Appropriate Technology Assistance Service (NATAS)

Solar Technical Information Program (STIP)

Federal Laboratory Consortium (FLC) 


\section{Other Federal Programs:}

Housing and Urban Development (HUD) Public Housing

Other HUD Programs

National Institute of Standards and Technology (NIST) Office of Research and Technical Applications (ORTA)

NIST Center for Building Technologies (CBT)

Trade and Professional Organizations:

National Association of Regulatory Utility Commissioners (NARUC)

National Association of State Energy Officials (NASEO)

The U.S. Conference of Mayors

National Association of Home Builders (NAHB)

NAHB Research Center

National Institute of Building Sciences (NIBS)

Building Thermal Envelope Coordinating Council (BTECC)

Each of the organizations contacted is discussed briefly below.

Results of Organizational Discussions

\section{DOE Programs}

Eight DOE programs were contacted. Five of these fell under the former Office of State and Local Assistance Programs. The other three are the Federal Energy Management Program, the Energy Related Inventions Program, and the Small Business Innovation Research program.

The Office of Technical and Financial Assistance, which replaced OSLAP, administers the five major national grant programs:

1. The State Energy Conservation Program provides financial and technical assistance to states to establish and support energy conservation programs at state and local levels.

2. The Energy Extension Service was designed to provide information on energy conservation to the general public.

3. The Institutional Conservation Program originally focused on schools and hospitals and now administers voluntary 50/50 matching grants for energy efficiency projects in institutional buildings.

4. The Weatherization Assistance Program provides services and products to assist low-income households, particularly those of the elderly and the handicapped, to reduce energy consumption and costs.

5. The Energy Related Inventions Program provides support to inventors for technology and business development in producing and marketing new energy products.

If pending legislation is enacted, the EES would be rolled into the SECP, which would carry forward its functions.

These programs have been supported by Congressional appropriations, by petroleum violation escrow funds, and by state funds. Because the programs are administered by the states, the former Office of State and Local Assistance Programs (OSLAP) found it useful to sponsor an annual All-States meeting where the cognizant state officials can convene to share information and discuss common problems. 
In addition, OSLAP programs published and distributed newsletters and maintained infornal networks as means of communication.

These programs were mandated to disseminate information on energy efficiency, provide technical assistance, evaluate energy program designs, conduct research in support of these activities, and support the actual implementation of energy programs, including the installation of measures in buildings. These programs therefore represent the potential for a critical interface between DOE's R\&D programs in energy efficiency and renewables and the promulgation and use of research results to certain audiences--largely state and local agencies responsible for administering and carrying out the grant programs.

The Federal Energy Management Program develops policy and regulations for energy use in the federal sector. FEMP also prepares annual reports to the President and Congress on federal energy management. Through the national laboratories, FEMP provides technical assistance on energy efficiency to agencies. The program also publishes a quarterly technical bulletin. The $80 \%$ of federal buildings belonging to the Department of Defense yield a $\$ 1.6$ billion annual energy bill. Federal buildings are of particular interest for two reasons: (1) the opportunities for both energy and taxpayer dollar savings are vast, and (2) federal buildings can be used as demonstration projects and examples of energy efficiency accomplishments in commercial buildings for other public- and private-sector organizations. (FEMP is now one of the programs within OBT.)

The Energy Related Inventions Program and the Small Business Innovation Research Program support the development and commercialization of innovative technologies. Neither program focuses solely on energy efficiency technologies; however, conservation and renewables technologies are supported in each program. Both programs stimulate teclmological innovation and work with small, entrepreneurial firms. These programs could be a conduit for R\&D results through the interaction of inventors and entrepreneurs with national-laboratory and corporate scientists working on similar or related problems. This type of scientific information exchange could aid in the development of products and processes that result from scientific synergy. OBT could also include new technologies from these programs in its technology transfer efforts.

\section{Federal Information Services}

Four federally supported information services were contacted: the Conservation and Renewable Energy Inquiry and Referral Service (CAREIRS), the National Appropriate Technology Assistance Service (NATAS), the Solar Technical Information Program (STIP), and the Federal Laboratory Consortium (FLC).

The Conservation and Renewable Energy Inquiry and Referral Service used to be known as the National Solar Heating and Cooling Information Center (NSHCIC) and was operated by the Franklin Institute in Philadelphia during the late 1970s and early 1980s. In those days, the program was funded at approximately $\$ 6$ million annually. In recent years, DOE has funded CAREIRS at about $\$ 1$ million annually to provide material to the general public on energy conservation and renewable energy. CAREIRS emphasizes the development of materials appropriate for use by the general public, educators, students, libraries, and professional and trade associations. CAREIRS distributes 147 fact sheets on energy topics. The CAREIRS service has not been evaluated, although the staff logs inquiries and referrals handled. The information provided is generic and responses are not tailored to specific inquiries.

The National Appropriate Technology Assistance Service provides information services and technical assistance in implementating energy efficiency and renewable energy technologies to individuals, state and local energy managers, small businesses, farmers, architects, builders, educational institutions, and others. The responses to inquiries are tailored to meet specific needs. NATAS also develops articles and publications on energy topics, makes referrals, and provides technical assistance on business strategies. The tailored nature of the responses makes this service particularly useful to those interested in developing, marketing, and applying energy efficiency and renewable energy technologies. 
The Solar Technical Information Program also provides technical information on renewable energy research and technologies to scientific, industrial, and public-sector audiences. STIP packages current technical information in concise form tailored for the intended audiences. In addition to referrals, STIP provides tailored responses to inquiries. STIP emphasizes the development of technical information products, such as periodicals, publications, exhibits, and reference works on solar energy and energy efficiency R\&D, technologies, and programs. Located at the Solar Energy Research Institute in Colorado, STIP has special expertise in renewable energy technologies and primarily serves the scientific and business community rather than energy end users.

The Federal Laboratory Consortium encompasses the R\&D of the federal laboratory system, and thus is not limited to energy efficiency technologies. It serves the technology transfer needs of trade and professional groups representing small businesses, industry, and state and local governments. FLC's principal purpose is to facilitate technology transfer from federal laboratories to private- and publicsector organizations. It maintains a clearinghouse on scientific topics being pursued at the laboratories; publishes a monthly newsletter; provides training on technology transfer; and hosts conferences, demonstration programs, and other activities. The FLC has no special expertise in energy technologies; its strength lies in its ability to access energy researchers wherever they are located in the nation's laboratory system. Such access would be of principal interest to buildings researchers.

\section{Other Federal Programs}

The federal programs beyond DOE that were explored as part of the current effort included programs at the U.S. Department of Housing and Urban Development (especially public housing and six other types of HUD programs) and at the National Institute of Standards and Technology (including the Office of Technology Commercialization and the Center for Building Technology).

HUD Public Housing, working through the more than 3,000 public housing authorities nationwide, administers the public housing program with 11,000 public housing projects and approximately 1.3 million units housing more than 3 million occupants. The HUD program subsidizes an energy bill totaling some $\$ 800$ million annually. Public housing projects use twice as much energy as privatesector housing; the savings potential is $\$ 500$ million a year to put public housing at the same level. An estimated \$1 billion in energy efficiency improvements is needed in public housing. The opportunity for energy efficiency improvements is vast.

Other HUD programs that offer significant potential for energy efficiency improvements fall under six categories: (1) insurance programs for mortgages and loans, (2) direct loans, (3) subsidized housing, (4) Community Development Block Grants, (5) Rehabilitation Assistance Program, and (6) Govemment National Mortgage Association (GNMA). Together with public housing, these projects significantly affect the nation's housing and the energy used in housing. HUD's energy bill for public and other assisted housing approaches $\$ 1.5$ billion each year. HUD provides approximately $\$ 1.7$ billion annually for capital improvements and major repairs for public housing, and \$2.9 billion each year for community development, about a third of which is used for property rehabilitation. HUD acquires 86,000 "HUD Homes" each year and sells them as is, with no improvements. Altogether, about 5.4 million housing units are affected by HUD policies and programs. With joint planning and DOE technical assistance activities, the relevant HUD programs could be transformed into vehicles for improving energy efficiency in the nation's housing using cost-effective approaches. These programs could still meet their mandates, and they could do so more efficiently.

The National Institute of Standards and Technology recently reorganized and replaced its Office of Research and Technology Applications with an Office of Technology Commercialization (OTC). This office specializes in technology transfer. The OTC has surveyed the states concerning their use of technology as part of economic development programs. The OTC located 230 organizations spending $\$ 620$ million annually on economic development programs. The OTC is sponsoring a workshop series for states to inform them about federal resources. Among the federal agencies, NIST has a particularly good rapport with industry. Working with NIST to transfer energy-efficient 
technologies through economic development organizations at the state level, and possibly to link state energy offices with state economic development offices, could be a significant opportunity.

NIST's Center for Building Technology works to increase the usefulness, safety, and economy of buildings through the advancement of building technology. It works on technical bases for improved structural and earthquake design criteria. CBT provides technical bases for selecting cost-effective materials, such as protective coatings, roofing systems, and cement hydration. In addition, CBT provides modeling, measurement, and test methods for using automation in construction, improving the quality of the indoor environment, and improving the perfornance of building equipment. CBT runs a Building Technology Symposia series, attended mostly by federal agency personnel, that presents information on state-of-the-art technologies using one-day fornats. Audiences could be expanded to include decision makers affecting building design or other ways in which energy is used.

\section{Trade and Professional Organizations}

While many relevant trade and professional organizations could have been included here, time and resources limited the current effort to seven organizations: (1) the National Association of Regulatory Utility Commissioners, (2) the National Association of State Energy Officials, (3) the U.S. Conference of Mayors, (4) the National Association of Home Builders, (5) the NAHB Research Center, (6) the National Institute of Building Sciences, and (7) the Building Thermal Envelope Coordinating Council.

The National Association of Regulatory Utility Commissioners is important because of utility integrated resource planning (IRP). IRP includes both supply and demand technologies and fosters cost (not necessarily energy use) reduction, although frequently the two overlap. NARUC membership includes state, federal, and Canadian public utility commissioners responsible for regulating utility companies and the telephone, water, gas, insurance, banking, and taxicab industries. NARUC, a source of infornation for the commissioners, publishes a weekly newsletter and holds conferences. NARUC committees develop commission policies on an array of topics. The Energy Conservation Committee develops NARUC policy and presents resolutions conceming energy efficiency to the full membership. The NARUC commissioners and staff want to know the latest developments in lighting, windows, and other energy efficiency and renewable energy technologies. They need solid evidence of technology performance and effective energy service delivery programs.

The National Association of State Energy Officials functions to update the states on activities in Washington and to act as a liaison between state and federal officials. NASEO publishes a quarterly newsletter and sponsors two meetings each year. Among the organization's committees are energy emergencies, integrated energy planning, SECP, appliances and building standards, R\&D, and global warming. OSLAP staff were interested in relationships with state officials responsible for administering state and local grant programs, and NASEO is the officials' professional association. One opportunity to improve buildings energy efficiency through NASEO is to deal with state concems about improving the energy efficiency of state-owned buildings.

The U.S. Conference of Mayors represents mayors of cities of 30,000 or more population and deals with a broad array of urban issues. The Conference has access to an extensive network of urban decision makers, publishes a semimonthly newspaper, and holds two major meetings each year. The established communications mechanisms could offer opportunities to promulgate energy efficiency information of interest to city administrators.

The National Association of Home Builders represents some 50,000 home builders and 107,000 others in related occupations. Affiliated with NAHB are 800 state and local home builder associations (HBAs). Information flows from NAHB to the HBAs, each of which has its own newsletters, seminars, meetings, and educational programs. NAHB owns the Home Builders Institute, which offers energy courses and seminars. NAHB also maintains a bookstore and publications catalog. NAHB is developing a program involving standards development, builder training and education, certification and quality assurance, research, and promotion and marketing. 
The NAHB Research Center is a wholly-owned, not-for-profit subsidiary of the NAHB, with a threefold mission: (1) to conduct applied research on buildings technology, (2) to promote quality standards in building materials and construction, and (3) to help maintain the U.S. building industries' competitive position. The Center has a Research Home Park that tests technologies, documents results in major trade publications, and displays them to the 2,500 builders attending the annual spring meeting. The Center's staff write articles about buildings technologies for a variety of magazines. The Center offers opportunities in research collaboration and in demonstrations of technologies and practices of particular interest to builders.

The National Institute of Building Sciences is a nongovemment, nonprofit corporation established in response to federal statute. NIBS was conceived as a public/ private partnership to resolve technical and regulatory issues facing the nation's housing and building processes. The organization's membership includes representatives from across the building community, including public interest groups, all levels of government, consumers, code officials, architects, engineers, builders, developers, product manufacturers, and standards organizations. NIBS efforts relate especially to performancecriteria based standards and other technical provisions to evaluate building products, systems, and component parts. NIBS also works to facilitate the use of performance criteria in certification, listing, and labeling programs. Among its activities, NIBS maintains the Construction Criteria Base (CCB), a data base on building specifications, standards, codes, and other technical criteria. CCB information is provided in CD-ROM form to a rapidly growing number of subscribers (currently approaching $1,000)$, many of whom are design professionals.

The Building Thermal Envelope Coordinating Council has an established relationship with DOE. BTECC was established as an independent council under NIBS auspices to coordinate industry and government R\&D efforts in building thermal envelope materials and technologies. Developing periodic national plans for the building envelope industry is a principal activity. BTECC focuses on research and technical activities related to improving materials, components, and systems. BTECC also stimulates the use of new and existing technology and technology verification and coordinates thermal envelope and service system interfaces. BTECC has established research coordinating committees made up of industry, government, and university representatives.

\section{Review and Recommendations}

The Technology Transfer Advisory Group reviewed the material in these briefs and informally evaluated it, applying the criteria developed for assessing OBT technology transfer activities (discussed in the next section). Although the group insisted that most technology transfer should occur on a technology-by-technology basis, it reached a consensus that OBT should develop relationships with staff at these organizations. Because of resource limitations, OBT management will need to set priorities among the organizations with which they will initiate discussions on interorganizational linkages. Each team member distributed 10 "votes" among the organizations listed, and in this manner the team defined the organizations that the Advisory Group is recommending to OBT management as having top priority:

\section{Federal Energy Management Program}

2. U.S. Department of Housing and Urban Development

3. National Association of Home Builders

4. National Institute of Standards and Technology (both the Office of Technology Commercialization and the Center for Building Technologies). 
The following were also ranked as equally important as each other in the near term:

- Office of Technical and Financial Assistance

- National Appropriate Technology Assistance Service

- National Association of Regulatory Utility Commissioners

- National Association of State Energy Officials.

The Advisory Group recommended that OBT management should continue its exploration of the potential for interorganizational linkages to transfer energy efficiency technologies. The priorities established should be revised periodically as new opportunities are defined.

Eight kinds of audiences for OBT tools, technologies, and practices based on functional roles were defined. These kinds of audiences are distributed across a wide variety of organizational types. For example, energy program implementers may be found at utility companies, small consulting firms, community action agencies, state energy offices, and national laboratories. These functional audiences form networks based on common needs for information. To reach them effectively, OBT needs to be sophisticated in its approach to its audiences through a variety of organizational conduits, using segmentation techniques to provide credible information through trusted channels. This is discussed further in the section on frameworks.

One meaningful technology transfer strategy OBT could use is to link its R\&D program with programs and organizations whose established missions involve disseminating energy efficiency information, implementing measures, regulating energy production and use, or representing relevant trades and professions. Based on a partial exploration of the opportunities for such linkages, the team concluded that OBT would find it particularly useful to actively pursue liaisons with FEMP, with HUD programs, with the NAHB, and with NIST. Other significant opportunities for linkage exist with the Office of Technical and Financial Assistance (OTFA), NATAS, NARUC, and NASEO. Linkages with other organizations that were not included in the current planning effort should be explored, and those that appear productive should continue to be developed in the future. The team views the development of linkages as a long-term task. 


\section{DECISION PROCESSES FOR TECHNOLOGY TRANSFER ACTIVITIES}

The manner in which the OBT program selects and funds its technology transfer activities can enhance or detract from the effectiveness of the enterprise. This section of the planning framework document presents recommended criteria for evaluating activities, describes the budget cycle, and presents two vehicles for program review, both of which are recommended by the team.

\section{Criteria}

The Technology Transfer Advisory Group developed a set of criteria against which candidate technology transfer activities could be assessed. These criteria relate to the activity's

- Energy savings potential

- Cost-effectiveness in transferring technology

- Leveraging of existing resources of other organizations

- Effectiveness in reaching unreached or underreached key audiences

- Congruence with the OBT mission and strategy

- Use of innovative approaches

- Contribution to balance across missions and audiences.

The Advisory Group did not weight the relative importance of these criteria in ranking organizations or activities in recommendations to OBT. In conducting their work, however, team members found, in most instances, that they could at least informally apply these criteria with little difficulty.

\section{Budget Cycles}

The planning and budgeting cycle for the Office of Building Technologies affects the decision-making process for the Office's projects. This cycle is governed by the rhythm of the Congressional appropriations process each year. As an example, we present the sequence of events for a cycle in which FY 1990, FY 1991, and FY 1992 projects are affected.

\section{FY 1990 Cycle}

September 1989

Final FY 1990 OBT activities

\section{FY 1991 Cycle}

January 1990

February 1990

June 1990

Fall 1990

September 1990

January 1991
FY 1991 budget to Congress

Deadline for plan, new initiatives for FY 1991

Testimony on FY 1991 budget

OBT selects FY 1991 projects (tentative)

Congressional budget approval

OBT selects FY 1991 projects (second round)

FY 1991 funds available

National Energy Strategy available for implementation 
FY 1992 Cycle

February 1990

New initiatives for FY 1992 are due from program managers and laboratories

May 1990

Internal Review Budget (IRB) (detailed activities for FY 1992

August-

November 1990

Office of Management and Budget review

January 1991

FY 1992 Budget to Congress

February 1991

Testimony on FY 1992 budget

June 1991

OBT selects FY 1992 projects (tentative)

Fall 1991

Congressional budget approval

September 1991

OBT selects final FY 1992 projects (second round)

\section{Program Review}

The team recommends to OBT management that it establish a review process for Office-wide (and perhaps, ultimately, the entire program's) technology. transfer activities. As envisioned by the team, the review process would emerge from three activities: (1) initiating an intemal OBT management review of technology transfer, (2) convening one or more technology transfer roundtables, and (3) establishing a Technical Review Panel for Technology Transfer.

\section{Internal OBT Management Review}

The team recommends that OBT management focus attention on the recommendations from the technology transfer planning effort, and consider how the Office-wide technology transfer effort can support the overall OBT R\&D program most effectively. Several actions could be taken; for example, management could reward program managers' efforts on behalf of technology transfer in performance evaluations, convene an intemal technology transfer working group with representatives from each OBT division, and hold a workshop on technology transfer for program managers. The intemal review process should be established so that it remains active and involved over time, coordinated with the activities of extemal technology transfer review groups, such as the roundtable and the Technical Review Panel, should these be established.

\section{Technology Transfer Roundtable(s)}

The Technology Transfer Advisory Group recommends that OBT convene an energy technology transfer roundtable or series of roundtables. In December 1984, a Building Industry Roundtable on Technology Transfer and Research Utilization, sponsored by DOE, was convened. Some 35 participants represented a broad spectrum of building community organizations. The meeting's purpose was to identify the constraints, discontinuities, limitations, and inadequacies in the existing technical information dissemination procedure, and to recommend new, better procedures.

That roundtable's recommendations were incorporated, to a certain degree, in Office technology transfer activities. For example, the roundtable recommended that the Office examine the process of handbook revision and enter into it more effectively. In the 5 years that have elapsed between that roundtable 
and the current technology transfer planning effort, BCS, the national laboratories, and their contractors became increasingly more involved in ASHRAE handbook revisions.

OBT management could envision how the Office will be transferring technology in the future. In that future, these could be examples of characteristic activities and outcomes:

- Each project will have a technology transfer component built in that has been evaluated by technology transfer experts.

- The Office will maintain collaborative activity with at least 10 major building trade and professional associations.

- The Office will have provided planning and technical assistance support to HUD to retrofit federally supported public housing and to provide a home energy rating system to be used in developing a model procedure for energy-efficient mortgages.

- The Office will have established an effective liaison with the Federal Energy Management Agency, and energy efficiency technologies will be included in the design of new federal buildings, as well as increasingly included in the retrofit of existing federal buildings. An annual meeting presents results to a federal building audience.

- The Office will have established an effective liaison with state and local assistance programs, resulting in a time reduction from 5 to 2 years in getting new technologies included in such grant programs as WAP and SECP.

The roundtable should be reconvened, with many of the same participants, as soon as possible. The timing of such a meeting is significant. Five to six years is an appropriate length of time since the last roundtable to assess the program's progress. The current context is OBT's strategic planning for its program's future direction, the increased significance of technology transfer's role in the national buildings energy efficiency $R \& D$ program, and the emphasis the new administration is placing on technology transfer within the National Energy Strategy.

Linking products of OBT R\&D activities with established programs, both federal and nonfederal, and transferring technology through those programs are key recommendations of the advisory group to DOE. The advisory group is recommending that OBT establish a Technical Review Panel (TRP) for its technology transfer program. With representation from the OBT program itself, private and public sectors, national laboratories, and other technology transfer programs, the panel can continue to serve the ad hoc Advisory Group's functions on an ongoing basis. The Panel would review and evaluate technology transfer activities, establish priorities, and recommend effective activities to OBT management. Preparatory to establishing a TRP on technology transfer, the roundtable would be useful in briefing users of OBT information and technologies about the OBT program, OBT technology transfer plans, and new initiatives. Roundtable participants would be a potential source of TRP members.

The roundtable's purposes would be fivefold:

1. Assessing user needs for buildings energy technology transfer. The roundtable will focus users on and inform them about technology transfer problems and possible solutions. Participants include individuals in technology ransfer, product development, buildings research, and information dissemination, located in a variety of trade and professional associations, information media, federal agency programs, and national laboratories.

2. Encouraging participants to transfer buildings energy technology through their own organizations. The roundtable would provide the participants an opportunity to network with others interested in technology transfer, working through one-on-one interactions with key people. This improves the linkages between OBT and its multiple user communities and fosters 
relationships among interested parties to encourage mutual support to better accomplish technology transfer.

3. Receiving participant feedback and commentary on OBT technology transfer products and processes. This involves identifying participants' needs for information generated by OBT and others on buildings energy efficiency and identifying how to deliver that information to them and to others most effectively.

4. Informing participants. The roundtable will emphasize the importance of the technology transfer program to the nation's energy strategy in realizing the benefits of our investment in buildings energy efficiency R\&D. It will also inform participants about the role of technology transfer envisioned in the National Energy Strategy.

5. Provide information about and receive feedback on the National Energy Strategy technology transfer component. The draft National Energy Strategy reports on technology transfer will be available before the roundtable begins. Participants will have an opportunity to comment on the direction of the National Energy Strategy as it relates to technology transfer.

Participants would receive three sets of materials before the roundtable begins:

1. A description of a draft of the future envisioned for the OBT technology transfer program, and a precis conceming the technology transfer component being developed as part of the National Energy Strategy

2. A set of materials currently produced as part of the OBT technology transfer program

3. A questionnaire conceming their needs and interests.

They would be asked to look over these materials and submit their questionnaires to organizers before the roundtable is held.

The roundtable could follow a workshop format, with breakout groups to discuss assigned topics and consensus-sharing with the group as a whole. Its agenda would cover such topics as

1. What technology transfer activities have participants undertaken? What has worked and what has not, in their experience?

2. How can we effectively communicate within and across organizations and programs? What are the opportunities and barriers?

3. What are the mutual concerns of OBT and roundtable participants?

4. How do participants evaluate the future envisioned for OBT technology transfer? BEACON? The Technical Review Panel concept? OBT use of existing government programs and trade and professional association mechanisms? Other new initiatives in technology transfer? Advisory Group recommendations?

5. What advice would participants like to offer in developing a technology transfer component for OBT and for the National Energy Strategy?

An altemative to a single roundtable would be to have a series of roundtables organized for different audiences. For example, different roundtables could be held for builders, designers, and venture capitalists. These programs could focus on the information needs and technology transfer experiences relevant to these specific groups. Roundtables could be organized around specific programs or organizations, such as a roundtable on energy efficiency opportunities through HUD programs, or one on FEMP. These roundtables could explore opportunities for and barriers to energy efficiency through 
programmatic linking with OBT to transfer energy efficiency technologies. The roundtable agendas would vary by being tailored to the specific needs of the groups being addressed.

\section{Technical Review Panel}

ERAB (1985, Vol. I: 12) recommended that DOE should establish an advisory board of buildings experts to enhance technology transfer. The OBT Advisory Group for Technology Transfer recommends to OBT management that a TRP for technology transfer be established as a standing committee. This Panel should advise the OBT Program Manager on technology transfer aspects of the OBT program, including both division/project level and program-wide efforts. The appropriate size for the panel would be 8 to 12 participants.

Participants would include representatives from key private-sector users of buildings energy efficiency technologies and information, and one or two national laboratory specialists. The OBT Analysis and Technology Transfer Program Manager would nominate participants, and the list would be reviewed by the OBT Executive Committee. The Program Manager would make the final appointments to the panel, with the concurrence of the Office Director. The TRP could be organized and managed for DOE by one of the national laboratories (because DOE has to follow the Advisory Committee Act, which could impede formation of the group). Additionally, some national laboratory staff support might be needed for TRP functions.

The TRP would meet at least annually, and preferably semiannually, to review existing technology transfer plans and projects and to advise on future planning. The role of the TRP would have be to distinguished from, and coordinated with, the role and activities of the CADDET national team. The TRP chair would prepare a report to the Analysis and Technology Transfer Program Manager, providing review and recommendations that constitute guidance on strategies and policy directions, although not necessarily on specific activities.

TRP participants could be selected from among the attendees at the OBT Technology Transfer Roundtable(s) that the Advisory Group is also recommending (see below). Initial members would be appointed for 2-, 3-, or 4- year terms and could then be rotated off the TRP to accommodate new members' ideas. The meeting schedule could follow the budget and funding cycle, for example:

FY 1992-1993 Cycle

May 1991

TRP meets and begins defining its role and determining staff support needs; reviews existing plans and outcome of roundtable(s), if one or more are held; advises on the relationship between the National Energy Strategy and OBT technology transfer strategies; and advises on June submission for FY 1992 projects.

November 1991

TRP meets to review the relationship between the National Energy Strategy and preliminary strategies for FY 1993 technology transfer activities.

\section{FY 1993-1994 Cycle}

This cycle would continue with meetings in May and November each year.

\section{Summary}

The Advisory Group recommends that seven criteria be used to assess candidate technology transfer activities. These criteria relate to 
- Energy savings potential

- Cost-effectiveness in transferring technology

- Leveraging of existing resources of other organizations

- Effectiveness in reaching unreached or underreached key audiences

- Congruence with the OBT mission and strategy

- Use of innovative approaches

- Contribution to balance across missions and audiences.

The Advisory Group recommends that OBT management undertake a systematic, ongoing review process for the Office's technology transfer activities. This process could begin with a technology transfer roundtable (or series of roundtables) to obtain private- and public-sector reviews of and recommendations for the Office's technology transfer products and activities. The group further recommends that a Technical Review Panel be established to perform ongoing reviews of the relevance and effectiveness of technology transfer activities, and to advise program management of their comments. Additionally, the group recommends that OBT management establish an intemal process to assess technology transfer activities using the framework and criteria identified in this report. 


\section{FRAMEWORKS FOR DECIDING ON OFFICE-WIDE TECHNOLOGY TRANSFER ACTIVITIES}

OBT program management has ongoing responsibility for allocating resources to technology transfer activities in the most judicious manner possible for maximum impact. To decide rationally what the Office-wide technology transfer program's activities should be, OBT management may decide to employ techniques to evaluate the array of proposals for technology transfer that it continually faces. This section furnishes some examples of technology transfer activities generated as part of the planning effort. It describes some frameworks developed as part of the task that can be used to evaluate activities. One of these provides a systematic means for disceming the specific structural audiences that will reach functional audiences. A second framework exhibits a way that both funded and proposed activities can be evaluated against target audiences and technology transfer functions to test program balance.

\section{OBT Technology Transfer Functions}

The Technology Transfer Advisory Group was supposed to develop a framework that OBT management could use in assessing technology transfer activities. The group defined four technology transfer functions that. Office-wide technology transfer activities should accomplish under the Analysis and Technology Transfer Program. These functions involve the transfer of

\section{Research results}

2. New and existing OBT tools, technologies, and practices

3. New and existing non-OBT tools, technologies, and practices

4. Program awareness.

The transfer of research results refers to the scientific information exchange vital to an active R\&D program and to the cross-fertilization of ideas among government, national laboratory, and corporate scientists. Such information products as Buildings Energy Technology and Research in Progress are designed to help accomplish this function. Of course, a good deal of scientific information exchange is carried on at the project level, as well.

The transfer of new and existing OBT tools, technologies, and practices means engaging in activities, including information dissemination, that further the production, distribution, and installation of energy efficiency technologies such as low-e glass in windows and the use of DOE-2. Especially, the transfer should be accomplished with product manufacturers and energy intermediaries--those actually producing, designing for, and implementing energy efficiency measures.

The transfer of new and existing non-OBT tools, technologies, and practices has gained significance as a technology transfer issue with the advent of CADDET, in which the Office is an active participant in the promulgation of information about demonstrated energy technologies developed in foreign countries. CADDET publishes fact sheets on demonstrated technologies, and the fact sheets are then distributed by OBT. If OBT is indeed leading a national effort to increase the energy efficiency of the nation's buildings, the transfer of any workable technologies should probably be included.

Finally, the Office-wide technology transfer effort should engage in activities to increase program awareness across the range of audiences potentially interested in the results of the OBT R\&D program. This technology transfer function should be accomplished to enhance the probability of users' awareness and use of the program's R\&D results in a variety of ways, including scientific, educational, design, manufacture, construction, and other purposes that aid in increasing energy efficiency in buildings. Audiences would include public- and private-sector scientists, legislators, government officials, and consumers. Such information products as Energy Conservation Success Stories fall into this category. 
In planning across a 5-year horizon, OBT management could think in terms of the potential sequence of emphases given to different functions. For example, Figure 3 presents one possible approach to sequencing functions. This approach suggests that program awareness would receive significant emphasis early in the 5-year period, but this would drop off gradually, because we could assume that most users would have heard of the program after 5 years or so.

Office-Wide Technology Transfer

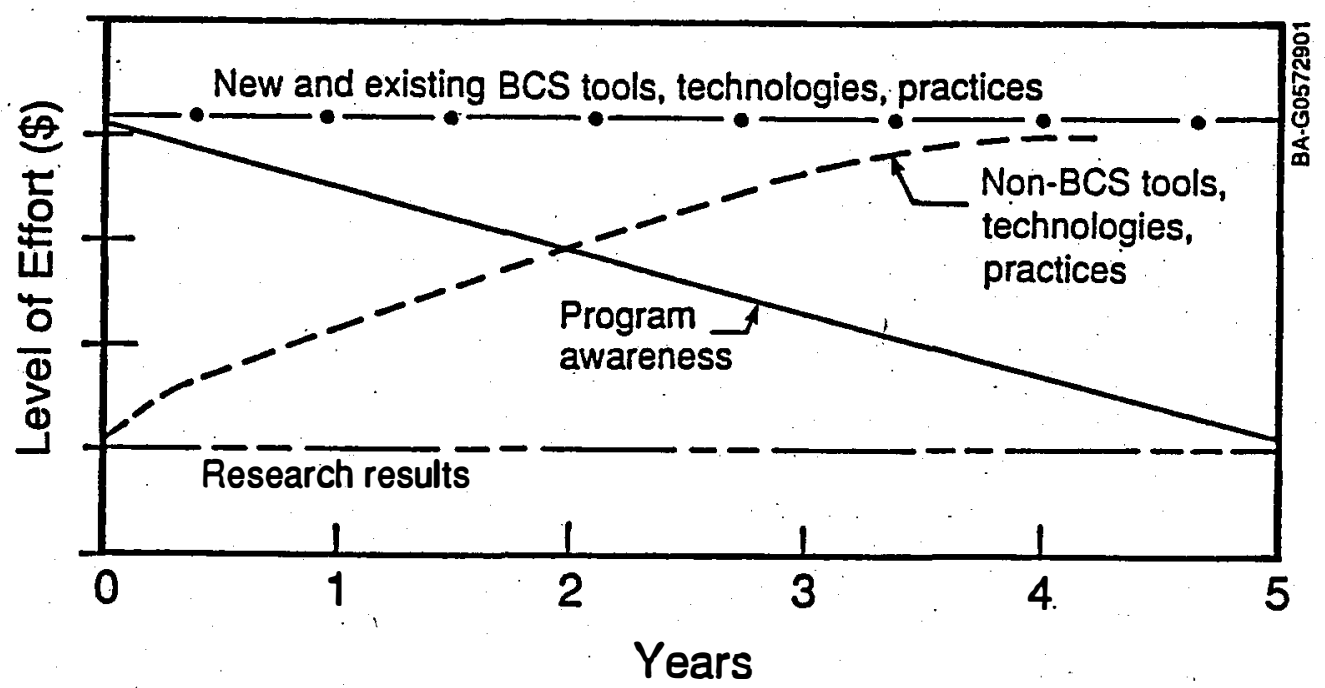

Figure 3. Potential Sequence of Technology Transfer Functions

The promulgation of research results would receive a relatively low but stable level of support over the 5-year period. The reason for this is that scientific information exchange through publication in the joumals, scientific reports, and presentations at conferences is funded primarily at the program and project levels. The Office-wide role in this mission is to gather and publish inventories of projects and publications as reference documents.

A high degree of ongoing support could be provided to transferring new and existing OBT tools, technologies, and practices to users. This type of effort could involve working through other organizations whose purpose is to plan and implement programs that actually deliver energy efficiency services and install measures in buildings. While some technology transfer efforts of this type occur at the project level, the team concluded that management and research support of technology transfer efforts, supported at the Office level through a variety of activities, would enhance those efforts and assist them in becoming more effective.

A relatively low level of initial support could be assigned to the transfer of non-OBT tools, technologies, and practices. This support would increase steadily over the 5-year planning period as OBT became more familiar with technologies developed in other sectors, private companies, and other countries that would be especially helpful domestically in conserving energy in buildings. These technologies would be transferred through the same channels that OBT is using for its own R\&D program products.

\section{A Framework for Assessing Technology Transfer through Organizational Linkages}

The Technology Transfer Advisory Group members realized that the four technology transfer functions they identified had to be accomplished by targeting specific audiences. For purposes of developing 
useful frameworks, the team developed a list of general functional target audiences. This list included the following:

- Building researchers nationwide, including public- and private-sector researchers

- Federal buildings, conservation programs, and legislative concems

- State and local buildings, conservation programs, and legislative concerns

- Private-sector manufacturers and distributors, energy intermediaries, conservation programs, and consumers/end users

- Internal DOE program managers and national laboratory staffs.

The group developed a useful planning framework by drawing a matrix with technology transfer functions as column heads and target audiences as row heads. The cells of this matrix were filled in with the names of specific organizations or programs through which information and technologies could be transferred to accomplish specific technology transfer functions with specific audiences.

This framework, used to identify organizational linkages through which specific technology transfer functions could be accomplished with target audiences, is presented in full in Appendix D. The framework on organizational linkages can serve as a guide to programs and organizations to which OBT can tum to accomplish certain kinds of technology transfer tasks.

Table 4 shows the column and row heads of the framework matrix. The programs and organizations defined as particularly useful conduits through which to transfer information and technologies are identified in the cells of the matrix. For example, to transfer research results to buildings researchers, OBT can use, among other channels, OSTI, publications from ORNL, and NTIS.

Using the framework provides a means by which OBT management can review how audiences for a given technology transfer function can be reached through programs and organizations designed to reach them. OBT can also determine, given any current mix of activities, whether all of the relevant types of audiences are being effectively reached through programs and organizations germane to them.

\section{Examples of Technology Transfer Activities}

As part of the technology transfer planning effort, almost 60 example activities that OBT could undertake for technology transfer purposes were identified. They were derived from four sources:

(1) the list of already existing analysis and technology transfer activities (shown in Appendix A);

(2) suggestions and informal proposals from various outside sources that had been submitted to OBT management; (3) activities identified by OBT program managers during the interviews with them; and

(4) ideas generated by team members. These activities were classified into four categories:

1. Activities resulting in information products, such as publications

2. Activities providing management support for technology transfer

3. Activities providing research support for technology transfer

4. Special activities (such as CADDET), events, and new initiatives.

In addition, a fifth category--developing and maintaining organizational linkages--was identified as a crosscutting type of activity.

Group members ranked these types of activities by assigning to them the proportion of resources (including funding and staff time) each should receive, as a percentage of 100 . These rankings resulted in the following mean scores: 
Table 4. Matrlx of Technology Transfer Functions by Target Audlences

\begin{tabular}{|c|c|c|c|c|}
\hline \multirow{3}{*}{$\begin{array}{c}\text { Target } \\
\text { Audlences }\end{array}$} & \multicolumn{4}{|c|}{$\begin{array}{c}\text { Technology Transfer } \\
\text { Functions* }\end{array}$} \\
\hline & (1) & (2) & (3) & (4) \\
\hline & \\
\hline \multicolumn{5}{|l|}{$\begin{array}{l}\text { Federal } \\
\text { Buildings }\end{array}$} \\
\hline \multicolumn{5}{|l|}{ Conservation programs } \\
\hline \multicolumn{5}{|l|}{ Legislative } \\
\hline \multicolumn{5}{|l|}{$\begin{array}{l}\text { State and local } \\
\text { Buildings }\end{array}$} \\
\hline \multicolumn{5}{|l|}{ Conservation programs } \\
\hline \multicolumn{5}{|l|}{ Legislative concerns } \\
\hline \multicolumn{5}{|l|}{$\begin{array}{l}\text { Private sector } \\
\text { Product manufacturers and distributors }\end{array}$} \\
\hline \multicolumn{5}{|l|}{ Energy intermediaries } \\
\hline \multicolumn{5}{|l|}{ Conservation programs } \\
\hline \multicolumn{5}{|l|}{ Consumers/end users } \\
\hline \multicolumn{5}{|l|}{ Internal DOE staff and national laboratories } \\
\hline $\begin{aligned} *(1) & =\text { Research results } \\
(2) & =\text { New and existing OBT tools, technol } \\
(3) & =\text { New and existing non-OBT tools, tec } \\
(4) & =\text { Program awareness }\end{aligned}$ & & $\begin{array}{l}\text { actice } \\
\text { Id prac }\end{array}$ & & \\
\hline
\end{tabular}

$\begin{array}{cll}\underline{\text { Rank }} & \text { Type of Activity } & \underline{\mathbf{X}} \\ 1 & \text { Information products } & 30 \\ 2 & \text { Management support } & 20 \\ 3 & \text { Research support } & 20 \\ 4 & \text { Special activities } & 15 \\ 5 & \text { Organizational linkages } & 15\end{array}$

These results reflect the team's opinion about the relative cost, as well as the relative importance, of types of activities. For example, information products tend to be costly, and team members said that they should receive $30 \%$ of the technology transfer resources available. Management support was thought to be less costly in direct dollar terms and more costly in terms of staff time. These activities should receive $20 \%$ of the resources available, in the team's estimation. 
The example activities ranged from discrete, small efforts to large, multiyear initiatives. On the small end of the continuum, for example, were suggestions to include technology transfer efforts in staff performance evaluations and to prepare a technology transfer handbook. On the large end was, for example, the Building Efficiency and Conservation Network (BEACON), proposing the establishment of a nationwide buildings energy technology performance data base and inquiry service.

The activities list generated as part of this planning exercise should be seen as representing a small sample of a potentially massive universe of possible actions that could be taken to disseminate information and transfer technologies. Numerous other actions could be undertaken that would be equally or even more effective. However, these activities had special relevance for the planning effort because they filled an identified need, or because they had already been funded for some time and therefore had historical precedence, or because OBT program managers and technology transfer specialists expressed special interest in them.

The activities were ranked in the following way. Each activity was listed on a separate index card, and each team member was provided with a set of cards. Team members were asked to sort from among the 59 cards the 20 activities that they thought were most significant. They then ordered the 20 cards they had selected from first (most important) to last (least important) in the set of 20 . This ordering represented the ranking each individual team member assigned to the activities. The individual rankings were combined into a team ranking. The box on the facing page summarizes the "top 20" activities resulting from this selection. Appendix E presents a list of the activities with a succinct description of each, along with the scores and ranking each received.

\section{A Framework for Assessing Technology Transfer Activities}

A matrix similar to the one used to identify organizational conduits through which OBT could transfer technologies to target audiences can be used to assess the coverage of activities across the range of functions and target audiences. Using such a framework can reveal whether or not the mix of activities that OBT is funding at any one time is as balanced as OBT management desires, or whether any given target audience is being inadvertently neglected.

The activities identified, regardless of whether they were ranked in the top 20, were classified according to the planning framework. Appendix F presents the results of that classification.

\section{Summary}

Four central technology transfer functions were defined for Office-level technology transfer: (1) transferring research results, (2) transferring new and existing OBT-developed technologies, (3) transferring non-OBT energy efficiency technologies, and (4) increasing awareness of the OBT program. Some part of the technology transfer resources available should be used for each of these functions. OBT management could vary the emphasis assigned to these missions across time; for example, an early push to increase program awareness could be slowly phased down to a lower level over a 5-year period.

The team developed a framework by creating a matrix using technology transfer functions as column heads and general target audiences as row heads. Two frameworks were generated by completing the cells of the matrix in two different ways: (1) identifying the organizational conduits to reach each target audience, and (2) identifying activities to accomplish the function for the type of audience identified.

About 60 example technology transfer activities were developed from OBT program managers, team members, existing projects, and outside sources. These were evaluated by using the criteria discussed earlier and ranked, yielding 20 activities that were recommended as the most important ones for OBT to consider in planning and funding its technology transfer program. 
The team recommended that the frameworks be used as heuristic devices as part of technology transfer program management in the future.

\section{"Top 20" Technology Transfer Actlvities}

\section{Rank Title}

1

2

3

4

5

Technology transfer handbook

OBT technology transfer roundtable

Center for the Analysis and Dissemination of Demonstrated Energy Technologies (CADDET)

Trade magazine news releases and articles

Building Efficiency and Conservation Network (BEACON)

Technical Review Panel for Technology Transfer

Research on segmentation of OBT user audiences

Modular display of OBT research accomplishments

Developing an evaluation design for technology transfer programs

Evaluation of technology transfer effectiveness

Technology transfer in performance evaluations

2 Providing technical assistance and requiring a technology transfer plan as part of all R\&D projects

Computer-based information systems for technology transfer

Annual overall OBT technology transfer plan

15 Having a national laboratory host ACSA Summer Institute on Energy and Environmental Systems

OBT Technology Transfer Award

Information kiosk on the OBT programs

Curriculum materials for technical schools

19 Implementing advanced building technologies by adopting architectural firms as information brokers

20 Electronic mail network for OBT and its national laboratories 


\section{BIBLIOGRAPHY}

Achenbach, P.R., W.W. Seaton, and W.T. Flynn. 1985. Proceedings of Buildings Industry Roundtable on Technology Transfer and Research Utilization. Richland, WA: Pacific Northwest Laboratory. April.

Brookhaven National Laboratory. 1988. Analysis and Technology Transfer Annual Report - 1987, DOE/CH/OO16-H1, Washington, DC: U.S. Department of Energy, Office of Buildings and Community Systems. July.

Brown, M.A. 1989. The OBCS Technology Transfer Program: A Progress Report. Oak Ridge, TN: Oak Ridge National Laboratory.

Brown, M.A. 1988. Technology Transfer Strategies of the U.S. Department of Energy's Conservation Program. Oak Ridge, TN: Oak Ridge National Laboratory. December.

Brown, M.A and S.C. Hite. 1985. An Evaluation of the Institute on Energy and Engineering Education. Oak Ridge, TN: Oak Ridge National Laboratory. April.

Brown, M.A., L.G. Berry, and R.K. Goel. 1989. Commercializing Government-Sponsored Innovations: Twelve Successful Buildings Case Studies. ORNL/CON-275. Oak Ridge, TN: Oak Ridge National Laboratory. January.

Brown, M.A., D.W. Jones, J.O. Kolb, and S.A. Snell. 1986. Technology Transfer for DOE's Office of Buildings and Community Systems: Assessment and Strategies. Oak Ridge, TN: Oak Rige National Laboratory. June.

Brown, M.A., D.L. White, R. Vories, and S. Kirchen. 1988. A New Technology Transfer Process for DOE's Residential and Commercial Conservation Program. Oak Ridge, TN: Oak Ridge National Laboratory. October.

Coleman, G.L. and S.D. Samples. 1989. Monthly Progress Report: Building Thermal Envelope Systems and Materials (BTESM) and Research Utilization/Technology Transfer Progress Report for DOE Office of Buildings and Community Systems. Oak Ridge, TN: Oak Ridge National Laboratory. April.

Copenhaver, E.D. 1985. Use of Broker Organizations in Technology Transfer and Research Utilization for the Buildings Industry. Oak Ridge, TN: Oak Ridge National Laboratory.

Davis, L.J., C.L. Bruneau, and D.L. Ivey. 1987. Technology Diffusion of Energy-Related Products in Residential Markets. Richland, WA: Pacific Northwest Laboratory. May.

Deonigi, D., N. Moore, S. Smith, R. Watts, M. Brown, and R. Noun. 1989. The Technology Transfer Process, Background for the U.S. National Energy Strategy. Richland, WA: Pacific Northwest Laboratory, December.

Energy Research Advisory Board (ERAB). 1988a. Research and Technology Utilization. Washington, DC: US Department of Energy, DOE/S-0067. August.

Energy Research Advisory Board (ERAB). 1988b. R\&D Initiatives for Energy Competitiveness. Washington, DC: U.S. Department of Energy, DOE/S-0061. March.

Energy Research Advisory Board. 1985. Guidelines for DOE Long-Term Civilian Research and Development. Volume I: Overview and Summary. December. 
Entigh, D.J., C.J. Andrews, D.C. Kenkeremath, J.E. Mock, and F.T. Janis. 1987. Guidebook for Technology Transfer Managers. Alexandria, VA: Meridian Corporation. June.

Farhar, B.C., and F. H. Abel. 1989. A Framework for Planning Energy Conservation R\&D for Buildings. Golden, CO: Solar Energy Research Institute.

Far, B.C., and C.T. Unseld, 1982. America's Solar Potential: A National Consumer Study. New York: Praeger Publishing Co.

Fulkerson, W., S.I. Auerbach, A. Crane, D.E. Kash, A.M. Perry, D.B. Reister, and C.W. Hagan, Jr. 1988. Energy Technology R\&D: What Could Make a Difference? Part I: Synthesis Report. Oak Ridge, TN: Oak Ridge National Laboratory. December.

Goel, R.K., and M.A. Brown. 1989. Commercializing Government Sponsored Computer Software. Oak Ridge, TN: Oak Ridge National Laboratory. March.

Harkreader, S.A., and D.L. Ivey. 1987. The Energy Investment Decision in the Nonresidential Building Sector: Research into the Areas of Influence. Richland, WA: Pacific Northwest Laboratory. April.

Ivey, D.L., and S.A. Smith. 1988. The Role of Market Research in the Commercialization of Technology. Richland, WA: Pacific Northwest Laboratory. March.

Davis, J. Michael. 1989. Speech to Demand-Side Management Conference. Boston, MA, November 16.

Meridian Corporation. 1988. Directory of Energy Efficiency Information Services for the Residential and Commercial Sectors. Alexandria, VA.

Mihlmester, P.E., J. Gonos, L. Freeman, and M.A. Brown. 1989. Final Report: Technology Adoption Strategy for the Existing Buildings Efficiency Research Program. Oak Ridge, TN: Applied Management Sciences, Inc.

Millhone, J. 1989. "Energy Efficiency in Buildings: The Situation in the United States." Draft. Office of Buildings and Community Systems, U.S. Dept. of Energy, Washington, DC, December.

Mohler, B.L., R.M. Scheer, and V. Bames. 1985. Consumer Decision and Behavior Research Agenda for the Office of Buildings and Community Systems. Richland, WA: Pacific Northwest Laboratory. December.

Roberson, B.F. 1988. Focus Group Discussion Among Owners and Non-Owners of Ground Source Heat Pumps. Richland, WA: Pacific Northwest Laboratory. July.

Roberson, B.F., and S.A. Harkreader. 1988. Focus Group Discussions of Daylighting Practices. Richland, WA: Pacific Northwest Laboratory. November.

U.S. Department of Energy. 1989. Technology Transfer Profile. Draft prepared by PE-10 and the Technology Transfer Advisory Committee, Washington, D.C., November 10.

U.S. Department of Energy. 1988a. Analysis and Technology Transfer Annual Report 1987. Washington, DC: Office of Conservation. July.

U.S. Department of Energy. 1988b. A Compendium of Energy Conservation Success Stories. Washington, DC: Office of Conservation. September. 
U.S. Department of Energy. 1988c. Energy Conservation Goals for Buildings. A Report to the Congress of the United States. Washington, DC: Office of Conservation. May.

U.S. Department of Energy. 1988d. Energy Conservation Multi-Year Plan: 1990-1994. Washington, DC: Office of Conservation. August.

U.S. Department of Energy. 1988e. Technology '88: U.S. Department of Energy R\&D Laboratory Technology Transfer Program. Washington, DC. December.

U.S. Department of Energy. 1987. Residential and Commercial Conservation Program Strategic Plan. Washington, DC: Office of State and Local Assistance Programs. February.

Weijo, R.O., A.K. Nicholls, and M.R. Anderson. 1988. The Identification of Equipment and Practices Being Developed by the Office of Buildings and Community Systems with Near-Term Commercial Potential. Richland, WA: Pacific Northwest Laboratory. November. 


\begin{abstract}
APPENDIX A
Abbreviated List of Recent DOE Building Energy Technology Transfer Organizations, Products, Events, Reports and Projects, and Analysis Projects
\end{abstract}


Abbreviated List of Recent DOE Building Energy Technology Transfer Organizations; Products, Events, Reports and Projects, and Analysis Projects

\section{Organizations}

Building Thermal Envelope Coordinating Council (BTECC) - located at New Jersey Institute for Technology. OBT and National Institute of Building Sciences (NIBS) provide technical assistance, not funding. They have research coordination committees on windows, walls, etc.; have established an information committee; have published three national plans for building envelope industry research (this is their primary activity). Cumulative: $\$ 10,000$ (four years); approximately $\$ 2,500 /$ year.

Building Thermal Envelope Systems and Materials (BTESM) - for roof, walls, insulation, etc., industry people (not a TT program). Provides a vehicle to distribute a monthly report from ORNL on technology transfer activities. Is an ORNL operation. Started FY 1978. Cumulative: $\$ 10,000$.

Center for the Analysis and Dissemination of Demonstrated Energy Technologies (CADDET) - for product manufacturers, intermediaries, and energy service delivery organizations in member countries. Established by the Intemational Energy Agency (IEA). Denmark, Sweden, Finland, Italy, Netherlands, Norway, Switzerland, United Kingdom, United States, Canada, New Zealand are members. Goal is the adoption by industry of successful energy efficiency technologies. Is developing database of demonstration projects; publishing a newsletter. Has produced 4 analysis reports and 40 brochures (one per demonstrated technology, including 6 from the U.S.). ORNL is the lead U.S. lab. Annual: $\$ 80,000$.

Conservation and Renewable Energy Inquiry and Referral Service (CAREIRS) - for consumers. Is run by someone in renewable energy; is not funded by OBT. Purpose is consumer education. OBT reviews fact sheets on conservation. Annual: $\$ 940,000$ for FY 1989 plus an estimated $\$ 25,000$ in free postage, totaling $\$ 965,000$. Cumulative: several million. Currently not funded by OBT.

Office of Scientific and Technical Information (OSTI) - for energy researchers. Is a federal DOE facility located at Oak Ridge National Laboratory, limited to energy. It's a requirement that all DOE reports go in to OSTI and then to NTIS (National Technical Information Service). OSTI publishes Buildings Energy Technology. Not funded by OBT; nature of linkage is already defined; should be described in Technology Transfer Manual.

\section{Products}

Inventory of Energy Design Tools and Exercises for University Architecture Classes - for architecture faculty. One-time curriculum document published by the University of Washington Department of Architecture. Completed in FY 1989. Cumulative: $\$ 15,000$ (one-time).

Building Energy Case Study Curriculum Materials - for architecture faculty. Published by Association of Collegiate Schools of Architecture. Contains three case studies. Currently under review. Second phase will begin in FY 1990. Annual: $\$ 42,000$. Cumulative: $\$ 84,000$ (2 years).

Simulating Daylight with Architectural Models - for architecture faculty. UCLA-produced manual on how to use physical models to develop and study daylighting in buildings. Completed in FY 1988. Cumulative: $\$ 20,000$ (one-time).

SOLAR-5 - for architecture faculty. CAD tool, produced University of Califormia. Actively used in at least 12 schools of architecture. PC and mainframe versions. Completed in FY 1987. Cumulative: $\$ 60,000$. 
Energy and Engineering Bibliography - for mechanical engineering faculty. Developed by ACEC. Spinoff from the Institute on Energy and Engineering Education. Published two times, most recently in FY 1989. Annual: $\$ 15,000$. Cumulative: $\$ 30,000$ (2 times).

ASEAM-2 - for practitioners, ESCOs, utilities, SEOs. ACEC and NESC are disseminating this software package measuring building energy performance, cost/benefit, and payback periods on altemative retrofit measures. Completed in FY 1988. Cumulative: $\$ 170,000$ (5 years).

Recent Publications of DOE's Office of Buildings and Community Systems - for building researchers and OBT program managers. ORNL-produced bibliography, not annotated. Lists BCS products; one-time publication covering 1985-1988 publications. Completed in FY 1989. Periodic: \$7,500.

Research Update - Existing Buildings Efficiency Research (EBER) - for national laboratory researchers and consultants. Presents the status of the EBER program in 1987-1988, done by ORNL. Not funded by BCS Analysis and Technology Transfer program; was funded by BCS EBER program.

Buildings Energy Technology - for building researchers. Annotated bibliography. Started January 1988, published monthly by OSTI. Annual: $\$ 35,000$. Cumulative: $\$ 70,000$ (2 years).

Replacement of OSTI's Standard Distribution Mailing List (UC-350) - for OSTI. Maintained by OSTI for the dissemination of BCS-supported reports to buildings researchers. ORNL completed this in FY 1989. Cumulative: $\$ 6,000$ (3 years).

Research in Progress - for the former Deputy Assistant Secretary for Conservation (DAS/C) and building researchers; OSLAP staff. OSTI-produced annotated project list. Started FY 1986, published every other year. One is planned for FY 1990. Annual: $\$ 17,500$. Cumulative: $\$ 75,000$.

Program Overviews (Technology Briefs) - for OBT program managers, buildings researchers, state energy offices and others. SERI-published two-page (on one sheet) documents describing elements of OBT R\&D program, such as IAQ, roofing research, and lighting research. Also published in Buildings Energy Technology. FY 1988: \$28,500; FY 1989: \$34,000. Started in January 1988.

Program Reviews - for DAS/C. SERI-produced booklets describing in general terms the organization of energy conservation research offices at DOE and briefly describing R\&D programs. (Energy Conversion and Utilization, Buildings and Community Systems, OTS, and OIP). FY 1989: \$122,000 (OBT funded \$34,000).

List of building trade publications - for OBT division directors only. ORNL subcontracted to Editors Ink of Washington. List includes editor and contact information, and brief description of readership and editorial scope. Completed in FY 1987. Cumulative: $\$ 7500$ (one-time).

Media Package - Energy Conservation Information about District Heating and Cooling - for community energy managers. Prepared by SERI. Included an article written on the subject plus a wide selection of photos and illustrations. Was picked up and published as a cover story in September 1987 issue of Heating/Piping/Air Conditioning magazine. FY 1987: \$15,000.

OBT-State initiative - for state energy offices. Jon Stone of OBT was attempting to document OBT R\&D products for state energy offices to let them know what the national laboratories could do; however, the product from this effort has not been approved for distribution by DOE upper management. The project is now dormant. Annual: $\$ 7500$. Cumulative: $\$ 15,000$ (two times).

Trade magazine news releases and articles - for trade press. ORNL subcontracted to Sumner-Rider. News releases are sent to various trade organizations and newspapers; if they pursue it, they are helped with articles to publish. Annual: $\$ 45,000$. Cumulative: $\$ 135,000$ (3 years). 
CAREIRS fact sheets - for consumers. Prepared by CAREIRS with OBT review. Cover such topics as insulation and passive cooling techniques. Sent in response to inquiries.

Energy Conservation Technical Information Guide, Volume 1, Resource Directory - for anyone interested in energy conservation. SERI-prepared directory to sources of information about energy conservation such as research centers, associations, directories, software, publications. Published in FY 1988. Cumulative: $\$ 88,000$ (WAPA $\$ 30,000$; OBT $\$ 58,000$ ) (one time).

Energy Conservation Technical Guide, Volume 2, Utilities - for utilities and SEOs. SERI document giving technologies, program options, and other summary information. Published in FY 1989. Cumulative: $\$ 57,100$ (OBT: $\$ 57,100$ ) (one time).

Energy Conservation Technical Information Guide, Volume 3 - Residential Buildings - for utilities and SEOs. SERI document with information on technology options for retrofit. Published in FY 1990. $\$ 56,000$ (OBT: $\$ 56,000$ ) (one time).

A Compendium of Energy Conservation Success Stories - for DAS/C. Not funded by OBT Analysis and Technology Transfer program; funded by DAS/C. $\$ 18,000$.

\section{Events}

Technology Transfer Information Meeting at OBCS in Washington - for BCS program managers. ORNL and contractors involved in the technology transfer program presented one-half-day briefings to inform OBT program managers about BCS technology transfer activities. Annual: $\$ 2,000$. Cumulative: $\$ 8,000$ (4 years).

Energy Efficient Technologies Exhibit, February 22-26, 1988 - for members of Congress. National laboratories put the exhibit on in the Cannon rotunda to inform members of Congress about DOE conservation programs. Each lab provided an exhibit. Officially, nothing was spent.

Summer Institute on Energy and Design - for architecture faculty. To maintain awareness among architecture faculty of energy as a major curricular issue. Was held annually from 1980-1987; then again in 1989; and one is planned for 1991. Twenty-one faculty attended the 1987 institute; 40 faculty attended the 1989 institute. Annual: $\$ 100,000$. Curnulative: $\$ 800,000$ (8 years).

Institute on Energy and Engineering Education - for mechanical engineering faculty. BTECC puts on the Institute for mechanical engineering faculty; 21 attended last institute. Was held annually from 1980 through 1986; again in 1988; and one is planned for 1990. Annual: $\$ 100,000$. Cumulative: $\$ 800,000$ from OBT.

Symposium on "Guidelines for Air Infiltration, Ventilation and Moisture Transfer," 1987 - for code officials, builders, SEOs. Put on by Building Thermal Envelope Coordinating Council (BTECC) to develop air infiltration, ventilation, and IAQ consensus standards for homes and other buildings. Consensus standards have not been developed yet. Cumulative: $\$ 10,000$ from BCS, cost-shared with other entities for the one-time event.

\section{Reports and Projects on Technology Transfer}

Technology Adoption Strategy for DOE's Existing Buildings Efficiency Research Program, April 1989 draft - for EBER program manager. Applied Management Sciences did the report. Purpose was to characterize the building energy service industry, describe the adoption process within industry, identify the paths through which retrofit technologies could be adopted, and develop a technology adoption strategy. Planning activity. Funded primarily by the EBER program. Cumula ive: $\$ 55,000$ (EBER: \$45,000; A\&TT: \$10,000). 
Innovation case studies - for OBT program managers. Produced statistics on market penetration that have been used several times already as evidence of OBT success. ORNL completed 12, and 3 case studies are pending on how OBT technologies diffused successfully (reached 5\% of market). Commercializing Government-Sponsored Innovations: Twelve Successful Buildings Case Studies. 1989. Annual: $\$ 30,000$. Cumulative: $\$ 120,000$ (4 years).

Advanced Housing Technology plan - for OBT program managers. Being developed by National Association of Home Builders (NAHB) with AD Little and Massachusetts Institute of Technology. $\$ 450,000$, three-year project characterizing the building industry and developing a plan on how to transfer OBT technology to them. To be completed in 1990 . Cumulative: $\$ 900,000$ ( $\$ 450,000$ from OBT) (3 years).

Monthly reports on technology transfer - for OBT managers and BTESM industry (walls, roofs, insulations, etc.). ORNL prepares monthly technical progress report sent to 300 people, periodic progress report on technology transfer (published in the OBT annual report on the Analysis and Technology Transfer program).

Inventory of OBT technology transfer activities - for OBT managers. ORNL-prepared briefing slides; periodic reports. Last one completed before the current effort was completed in FY 1988.

\section{Analysis Projects}

Least-Cost Utility Planning (LCUP) - for utility regulators and investor-owned utilities (IOUs). In FY 1988, 35 research and technology transfer projects were conducted in five areas: (1) integrated utility planning processes (IUPP), (2) issues and strategies, (3) technology assessment and market penetration, (4) analytical tools, and (5) technology ransfer. The TT projects were categorized as (1) information exchange, (2) information documents, and (3) assistance.

\section{Information exchange projects were}

- Promoting LCUP among state public utility commissions (PUCs) (NARUC)

- NARUC LCUP Handbook Volume II (LBL)

- The Northem Illinois Alliance (City of Chicago)

- Role of Renewable Energy in LCUP (Renewable Energy Institute)

- LCUP Information Network (LBL).

Information documents projects were

- Demand-side Thesaurus and Consumer Energy Council project (EPRI)

- Energygrams (OSTI)

- DOE LCÜP Information Summary (Energetics).

Assistance projects were

- Assistance to LCUP grantees (LBL, ORNL, PNL, BNL, ANL)

- Rocky Mountain Region LCUP support (SERI).

Identification and Screening of Promising Near-Term Technologies and Practices (Consumer Decision Research) - for OBT program managers. PNL examined all technologies and practices under development by OBT. Surveyed program managers to see what they thought were the users, 
paybacks, length of time and barriers to commercialization. Draft report lists technologies with neartern commercial potential that could benefit from marketing research and active TT programs (based on program manager subjective assessment). Report: The Identification of Equipment and Practices Being Developed by the Office of Buildings and Community Systems with Near-Term Commercial Potential (draft) 1988. $\$ 45,000$ in FY 1990. Cumulative: $\$ 87,600$ (2 years).

Focus Group Discussions among Owners and Nonowners of Ground Source Heat Pumps (GSHPs) (Consumer Decision Research) - for utilities, manufacturers and others promoting the heat pumps. PNL conducted three focus groups with GSHP owners and nonowner homeowners. Report: Focus Group Discussions among Owners and Nonowners of Ground Source Heat Pumps. 1988. [Note: Consumer decision research was funded at $\$ 130,000$ in FY 1986; $\$ 193,400$ in FY 1987; and $\$ 171,400$ in FY 1988.] This project: $\$ 50,000$ in FY 1988.

Focus Group Discussions of Daylighting Practices (Consumer Decision Research) - for architects and engineers. PNL conducted four focus groups of people with professional experience in working with daylighting, including architects and engineers. Results are to serve as a basis for developing marketing programs so that daylighting will be used more in building design. Report: Focus Group Discussion of Daylighting Practices. 1988. \$60,000 in FY 1988.

Commercial Daylighting Study - for architects, engineers, and designers of daylighting technology. PNL conducted a survey of a representative national sample $(N=300)$ of architects. Draft report "Baseline Results of the Daylighting Practices Survey of the Architecture Industry." April 1989. FY 1989: $\$ 67,000$.

Energy Efficiency Gas Furnace Purchases (Consumer Decision Research) - for OBT program managers. ORNL conducted a survey of gas fumace replacement buyers to identify factors affecting the decision to buy an energy-efficient gas furmace rather than an inefficient furnace. Annual funding: $\$ 60,000$ in FY 1986 and $\$ 60,000$ in FY 1987. Cumulative: $\$ 120,000$.

Appliance Standards - for federal govemment and product manufacturers. LBL is conducting an assessment of the impacts of appliance efficiency standards, including (1) an engineering analysis, (2) a consumer analysis, (3) a manufacturer analysis, and (4) an impact analysis on various groups.

Commercial Buildings Energy Standards - for federal government and buildings industries. PNL is working on modifying the current industry energy performance standard (ASHRAE 90A-1980) for commercial buildings. This standard would be mandatory for the design of new federal buildings and is intending to encourage adoption by other sectors of the buildings industries. The proposed rule was published May 6, 1987, and public comment has been received and incorporated. During FY 1989, publication of compliance software and field testing and education that demonstrate the standard are being performed. The standard should reduce energy use in new buildings $5 \%$ to $18 \%$ over current practice, with just more than half the savings in lighting. FY 1988: $\$ 417,000$. FY 1989: \$251,000.

Residential Building Energy Standards - for federal govemment and local code officials. PNL is developing two standards for new residential buildings, one that would be mandatory for federally procured housing and one that could be voluntarily adopted by local code agencies. This standard helps in the design and construction of energy-efficient homes. An interim standard was published in FY 1986 and public comment received in FY 1987. In FY 1988, the standards were revised. During FY 1989, a demonstration project was conducted and the software and user manual revamped. Cumulative: $\$ 700,000$ (2 years).

Building Energy Accounting System (BEAS) - for OBT management and national laboratory researchers. PNL compiles data on the existing stock of residential and commercial buildings and their energy consumption characteristics. BEAS output is a databook and a floppy disk. FY 1986: \$225,000; FY 1987: \$160,000; FY 1988: \$160,000; and FY 1989: $\$ 250,000$. Cumulative: $\$ 795,000$ (4 years). 
Building Energy-Use Compilation and Analysis (BECA) - for DOE program managers, building researchers, and building professionals. 'LBL has developed and maintained a database on measured energy perfornnance of buildings and equipment. Its purpose is to identify building design strategies and end-use technologies that save energy or modify electrical loads and are cost-effective. The database covers new residences, residential retrofits, new commercial buildings, commercial retrofits, load management measures, refrigerators, energy management systems, and electronic office equipment. FY 1986: \$460,000; FY 1987: \$300,000; FY 1988: \$200,000; FY 1989: \$250,000. Cumulative: $\$ 1,210,000$ (4 years).

International Residential Energy Use Data Base - for policymakers, forecasters, and analysts. LBL has compiled a database for 11 Organization for Economic Cooperation and Development (OECD) countries (Canada, Denmark, France, Germany, Holland, Italy, Japan, Norway, Sweden, the United Kingdom, and the United States) on population, dwelling stock by type, economic indicators, delivered energy consumption by fuel type, and climate data. It allows energy use trends to be analyzed cross-nationally. FY 1989: $\$ 130,000$.

Historical Estimates and Projections of Commercial Floorspace - for analysts involved with PNL's commercial-sector modeling activities. PNL has completed new estimates of historical commercial floorspace and projections to 2010. FY 1988: $\$ 15,000$; FY 1989: $\$ 25,000$. Cumulative: $\$ 40,000$ (2 years).

Residential Energy Conservation Policies and Programs in OECD Countries - LBL is developing descriptions of national residential energy conservation policies and programs in five OECD countries (Denmark, France, Japan, Sweden, and West Germany). Detailed results are in progress.

Residential Energy Use in Venezuela - for the Venezuelan Ministry of Energy and Mines and the major gas company in Venezuela. LBL is participating in this project to analyze residential energy demand patterns and conservation policy options in Caracas, funded primarily by its users. The project involves a survey of households, data analysis, and policy recommendations.

Strategic Planning - for the Buildings and Community Systems Executive Committee. SERI has developed, with a planning support group, a planning framework document that identified five different strategic approaches the Office could take in directing its program and has analyzed their impacts on different stakeholder groups. The document also identified seven emergent national concerms to which the Office could contribute some help (global warming, ozone depletion, buildings productivity, affordability of housing, competitiveness of U.S. industry, indoor living and working environments, and adequacy of electricity supply). In FY 1989, the project assisted the BCS Executive Committee in selecting and implementing of a new strategy for the 1990s. Report: $A$ Framework for Planning Energy Conservation R\&D for Buildings, 1989. Completed in FY 1989. Cumulative: $\$ 100,000$.

Advanced Energy Design and Operation Technology Research (AEDOT) - for architects. A software tool for building energy design and analysis. FY 1989: $\$ 40,000$. 
APPENDIX B

Tools, Technologies, and

Practices for Transfer 
Table B-1. Successfully Commercialized Off-the-Shelf Technologies Requiring. No Further Assistance

\begin{tabular}{|c|c|c|c|c|c|c|}
\hline $\begin{array}{l}\text { Name of } \\
\text { Measure }\end{array}$ & Energy Savings & $\begin{array}{l}\text { Common } \\
\text { Practice }\end{array}$ & Division & $\begin{array}{c}\text { Year } \\
\text { Introduced }\end{array}$ & $\begin{array}{c}\text { Market } \\
\text { Penetration }\end{array}$ & Sales \\
\hline $\begin{array}{l}\text { Low-e windows } \\
\text { (1985-88 savings: } \\
15 \text { TBtu; projected } \\
\text { 1992: 0.10 QBtu) }\end{array}$ & $\begin{array}{l}\text { Low-e coatings can reduce } \\
\text { energy requirements } \\
\text { associated with windows by } \\
20 \%-40 \% \text {, providing insulating } \\
\text { values to } R-3 \text { while } \\
\text { transmitting most of the } \\
\text { sun's light. }\end{array}$ & $\begin{array}{l}\text { Triple-glazed } \\
\text { windows }\end{array}$ & $\begin{array}{l}\text { Building } \\
\text { Systems }\end{array}$ & 1983 & $\begin{array}{l}1984-1-3 \% \\
1985-5 \% \\
1986-10 \% \\
1987-15 \% \\
1988-20 \% * \\
1990-25-50 \% * \\
(*=\text { estimates) }\end{array}$ & $\begin{array}{l}750 \text { million } \mathrm{ft}^{2} \text {, } \\
1985-1992 \text {; } \\
\text { by } 1997 \text {. low-e will be } \\
\text { the industry standard }\end{array}$ \\
\hline $\begin{array}{l}\text { DOE-2, a computer } \\
\text { program that simu- } \\
\text { lates building } \\
\text { energy performance }\end{array}$ & $\begin{array}{l}\text { Use of DOE-2 has contributed } \\
\text { to about a } 20 \% \text { reduction in } \\
\text { direct building energy use }\end{array}$ & DOE-2 & $\begin{array}{l}\text { Building } \\
\text { Systems }\end{array}$ & 1978 & $\begin{array}{l}110 \text { organiza- } \\
\text { tions listed } \\
\text { as example } \\
\text { users }\end{array}$ & $\begin{array}{l}\text { PC version } 300 / y r_{1} \\
\text { magnetic tape } 300 / y r_{0} \\
\text { will be replaced in } \\
1992 \text { by more advanced } \\
\text { software }\end{array}$ \\
\hline $\begin{array}{l}\text { Dielectric coating } \\
\text { for lighting fix- } \\
\text { ture (enhanced } \\
\text { reflectivity) }\end{array}$ & $\begin{array}{l}\text { None listed; cost decreases } \\
\text { up to } 40 \%\end{array}$ & $\begin{array}{l}\text { Anodized } \\
\text { aluminum } \\
\text { lighting } \\
\text { sheeting }\end{array}$ & Not listed & & $\begin{array}{l}\text { Used in road- } \\
\text { side lighting } \\
\text { fixtures }\end{array}$ & $\begin{array}{l}185,000 \text { and growing: } \\
\text { no help neaded }\end{array}$ \\
\hline
\end{tabular}

Source: Brown, Berry, and Goel (1989). 
Table B-2. Examples of Best Off-the-Shelf Buildings Technologies Still Requiring Assistance

\begin{tabular}{|c|c|c|c|c|c|c|}
\hline $\begin{array}{l}\text { Name of } \\
\text { Measure }\end{array}$ & Energy Savings & $\begin{array}{l}\text { Common } \\
\text { Practice }\end{array}$ & Division & $\begin{array}{c}\text { Year } \\
\text { Introduced }\end{array}$ & $\begin{array}{c}\text { Market } \\
\text { Penetration } \\
\end{array}$ & Sales \\
\hline $\begin{array}{l}\text { Solid-state ballast } \\
\text { (energy savings } \\
\text { from sales through } \\
\text { 1988: } 700 \text { million } \\
\text { kWh or about } 8 \text { TBw) }\end{array}$ & $\begin{array}{l}\text { Uses } 15 \%-30 \% \text { less energy } \\
\text { for same light output as } \\
\text { standard core ballast }\end{array}$ & $\begin{array}{l}\text { Standard core } \\
\text { ballast }\end{array}$ & Not listed & 1980 & $\begin{array}{l}1985-1.5 \% \\
\text { next } 10 \text { years: } \\
30 \%-50 \%\end{array}$ & $\begin{array}{l}7 \text { million units; all U.S. } \\
\text { manufacturers offer a } \\
\text { solid-state ballast and } \\
\text { are expanding sales } \\
\text { slowly }\end{array}$ \\
\hline $\begin{array}{l}\text { Unequal parallel } \\
\text { compressor system } \\
\text { (energy savings not } \\
\text { listed) }\end{array}$ & $\begin{array}{l}\text { Reduces energy use approx- } \\
\text { imately } 5 \%-17 \% \text { relative to } \\
\text { common practice }\end{array}$ & $\begin{array}{l}\text { Paired com- } \\
\text { pressor system } \\
\text { for supermarket } \\
\text { cooling systems }\end{array}$ & $\begin{array}{l}\text { Building } \\
\text { Equipment }\end{array}$ & Early 1980 s & $\begin{array}{l}1987-54 \% \\
\text { of the } 1987 \\
\text { display } \\
\text { cases sold }\end{array}$ & $\begin{array}{l}1987-1,160 \text { super- } \\
\text { market display cases in } \\
1987\end{array}$ \\
\hline $\begin{array}{l}\text { Flame retention } \\
\text { head oil bumer } \\
\text { (energy savings: } \\
\text { about } 530 \text { million } \\
\text { banrels. of oil } \\
\text { thr } 1987 \text {, or } \\
0.30 \text { quads) }\end{array}$ & $\begin{array}{l}\text { Reduces oil consumption } 18 \% \\
\text { for boilers; } 11 \% \text { for fur- } \\
\text { naces relative to pre-flame } \\
\text { retention technology; pro- } \\
\text { jected savings of } 0.14 \text { quad } \\
\text { by } 2000 \text { ) }\end{array}$ & $\begin{array}{l}\text { Flame retention } \\
\text { head oil bumer }\end{array}$ & $\begin{array}{l}\text { Building } \\
\text { Equipment }\end{array}$ & Mid-1970s & $\begin{array}{l}25 \% \text { of the } \\
12 \text { million } \\
\text { households } \\
\text { heating with } \\
\text { oil }\end{array}$ & $\begin{array}{l}\text { Through } 1985 \text { - about } \\
3 \text { million }\end{array}$ \\
\hline $\begin{array}{l}\text { Heat-pump water } \\
\text { heater (energy } \\
\text { savings thr 1987: } \\
\text { approximately } 200 \\
\text { million Btu) }\end{array}$ & $\begin{array}{l}\text { Water heating accounts for } \\
20 \% \text { of household energy } \\
\text { use in U.S.; uses one- } \\
\text { half the energy used by } \\
\text { electric resistance water } \\
\text { heaters; also provides } \\
\text { cooling and dehumidification }\end{array}$ & $\begin{array}{l}\text { Electric resis- } \\
\text { tance water } \\
\text { heater }\end{array}$ & $\begin{array}{l}\text { Building } \\
\text { Equipment }\end{array}$ & 1980 & $\begin{array}{l}\text { Minimal to } \\
\text { date }\end{array}$ & $\begin{array}{l}\text { More than } 40,000 \text { from } \\
1980 \text { to } 1987\end{array}$ \\
\hline $\begin{array}{l}\text { Radiant barriers } \\
\text { used with attic } \\
\text { insulation } \\
\text { (1985-87 savings: } \\
102 \mathrm{~K} \text { kWh, or } \\
1.2 \text { billion Bu) }\end{array}$ & $\begin{array}{l}\text { Radiant barriers capable of } \\
\text { blocking up to } 95 \% \text { of heat } \\
\text { transfer in the summer, in } \\
\text { the South, use would save } \\
900 \mathrm{kWh} \text { per household per } \\
\text { year }\end{array}$ & $\begin{array}{l}\text { Regular attic } \\
\text { insulation } \\
\text { without radiant } \\
\text { barriers }\end{array}$ & $\begin{array}{l}\text { Building } \\
\text { Services }\end{array}$ & 1985 & $\begin{array}{l}0.1 \% \text { of } \\
22 \text { million } \\
\text { homes }\end{array}$ & 1 million sq. $\mathrm{ft} / \mathrm{wk}$ \\
\hline
\end{tabular}


Table B-3. Tools, Technologies, and Practices Almost Ready for Commercialization and Needing Assistance

\begin{tabular}{|c|c|c|c|c|c|c|}
\hline Project & Definition & $\begin{array}{l}\text { Equipment } \\
\text { and/or } \\
\text { Practice }\end{array}$ & Division & $\begin{array}{l}\text { How } \\
\text { Ready } 1 \\
\end{array}$ & $\begin{array}{l}\text { Payback } \\
\text { Period }^{2} \\
\end{array}$ & $\begin{array}{l}\text { Transfer } \\
\text { Needs OBT } \\
\text { Assistance }^{3}\end{array}$ \\
\hline $\begin{array}{l}\text { Urban heat islands } \\
\text { (40\% savings) } \\
\text { (page B.1; see } \\
\text { source below) }\end{array}$ & $\begin{array}{l}\text { Energy use can be reduced by such } \\
\text { practices as increasing tree canopy } \\
\text { and by changing the reflectance of } \\
\text { roofs and paving surfaces }\end{array}$ & Both & $\begin{array}{l}\text { Building } \\
\text { Services }\end{array}$ & Ready now & 3-5 years & Yes \\
\hline $\begin{array}{l}\text { Integrated utility } \\
\text { planning processes } \\
\text { (mdirect savings) } \\
\text { (page B.26) }\end{array}$ & $\begin{array}{l}\text { Develops planning processes and } \\
\text { approaches that support the inclusion } \\
\text { of demand-side options in the prepa- } \\
\text { ration of utility energy resource plans } \\
\text { and programs }\end{array}$ & Practice & $\begin{array}{l}\text { Building } \\
\text { Services }\end{array}$ & $1-2$ years & N/A & Yes \\
\hline $\begin{array}{l}\text { Utility analytical } \\
\text { tools (mdirect } \\
\text { savings) (page B.29) }\end{array}$ & $\begin{array}{l}\text { Evaluate and develop analytical tools } \\
\text { including models and data that will } \\
\text { help plan and implement least-cost } \\
\text { utility plamning }\end{array}$ & Practice & $\begin{array}{l}\text { Building } \\
\text { Services }\end{array}$ & $1-2$ years & N/A & Yes \\
\hline $\begin{array}{l}\text { Solid fuel appliance } \\
\text { measurement methods } \\
\text { (indirect savings) } \\
\text { (page A.21) }\end{array}$ & $\begin{array}{l}\text { Identify low-cost methods for } \\
\text { measuring the efficiency } \\
\text { of solid fuel appliances }\end{array}$ & Both & $\begin{array}{l}\text { Building } \\
\text { Equipment }\end{array}$ & 1-2 years & N/A & Yes \\
\hline
\end{tabular}

Source: Weijo, RO., A.K. Nicholls, and M.R. Anderson. 1988. The Identification of Equipment and Practices Being Developed by the Office of Buildings and Community Systems with Near-Term Commercial Potential. (Draft) Richland, WA: Pacific Northwest Laboratories. November.

1 Weijo, Nicholls, and Anderson (1988), Table 3.1 on page 3.2.

2 Weijo, Nicholls, and Anderson (1988), Table 3.2 on pages 3.4-3.5.

3 Based on program managers' response to the item, "Will this equipment or practice require commercialization assistance from OBCS for it to succeed in the marketplace?" Data provided by Batelle Pacific Northwest Laboratories. 
Table B-3. Tools, Technologies, and Practices Almost Ready for Commercialization and Needing Assistance (continued)

\begin{tabular}{|c|c|c|c|c|c|c|}
\hline Project & Definition & $\begin{array}{l}\text { Equipment } \\
\text { and/or } \\
\text { Practice }\end{array}$ & Division & $\begin{array}{l}\text { How } \\
\text { Ready }\end{array}$ & $\begin{array}{l}\text { Payback } \\
\text { Period }\end{array}$ & $\begin{array}{l}\text { Transfer } \\
\text { Needs OBT } \\
\text { Assistance }\end{array}$ \\
\hline $\begin{array}{l}\text { Shared savings } \\
\text { (15\% savings) } \\
\text { (page B.12) }\end{array}$ & $\begin{array}{l}\text { Involves installation of more effi- } \\
\text { cient hardware, improved operation/ } \\
\text { maintenance practices or a combination } \\
\text { of the above by a third party; third } \\
\text { parties are compensated with a portion } \\
\text { of the savings that show up in the } \\
\text { utility bill }\end{array}$ & Practice & $\begin{array}{l}\text { Building } \\
\text { Services }\end{array}$ & Ready now & $3-5$ years & Yes \\
\hline $\begin{array}{l}\text { Diagnostic protocols } \\
\text { and analysis methods } \\
\text { (does not save energy) } \\
\text { (page B.14) }\end{array}$ & $\begin{array}{l}\text { A collection method that yields a } \\
\text { well-defined series of data points } \\
\text { that describe a building's energy } \\
\text { use; with proper analysis of these } \\
\text { data points, the system receives } \\
\text { the proper and most cost-effective } \\
\text { energy conservation improvements }\end{array}$ & Practice & $\begin{array}{l}\text { Building } \\
\text { Services }\end{array}$ & Ready now & 3-5 years & Yes \\
\hline $\begin{array}{l}\text { Corrosiveness of } \\
\text { insulation (does not } \\
\text { save enërgy) } \\
\text { (page C.4) }\end{array}$ & $\begin{array}{l}\text { Studies how the corrosivity of in- } \\
\text { sulation material is affected by } \\
\text { humidity and moisture }\end{array}$ & Practice & $\begin{array}{l}\text { Building } \\
\text { Systems }\end{array}$ & Ready now & N/A & Yes \\
\hline $\begin{array}{l}\text { Maintenance and } \\
\text { upgrade of DOE-2 } \\
\text { (does not save energy) } \\
\text { (page C.15) }\end{array}$ & $\begin{array}{l}\text { Develops new or enhanced capabilities } \\
\text { for the DOE-2 program; problems with } \\
\text { DOE-2 are solved; maintenance, } \\
\text { publishing, and distribution of docu- } \\
\text { mentation for DOE-2 is conducted } \\
\text { through this activity }\end{array}$ & Practice & $\begin{array}{l}\text { Building } \\
\text { Systems }\end{array}$ & Ready now & N/A & Yes \\
\hline $\begin{array}{l}\text { Perfluorocarton tracer } \\
\text { system (does not save } \\
\text { energy) (page C.23) }\end{array}$ & $\begin{array}{l}\text { Represents a passive measurement } \\
\text { technique designed to obtain reason- } \\
\text { able estimates of infiltrationfuenti- } \\
\text { lation in buildings using perfluorocarbon } \\
\text { tracer gases }\end{array}$ & Equipment & $\begin{array}{l}\text { Building } \\
\text { Systems }\end{array}$ & 1-2 years & N/A & Yes \\
\hline
\end{tabular}


Table B-3. Tools, Technologies, and Practices Almost Ready for Commercialization and Needing Assistance (continued)

\begin{tabular}{|c|c|c|c|c|c|c|}
\hline Project & Definition & $\begin{array}{l}\text { Equipment } \\
\text { and/or } \\
\text { Practice }\end{array}$ & Division & $\begin{array}{l}\text { How } \\
\text { Ready }\end{array}$ & $\begin{array}{l}\text { Payback } \\
\text { Period }\end{array}$ & $\begin{array}{l}\text { Transfer } \\
\text { Needs OBT } \\
\text { Assistance }\end{array}$ \\
\hline $\begin{array}{l}\text { Commencial standards } \\
\text { (no savings listed) } \\
\text { (page C.29) }\end{array}$ & $\begin{array}{l}\text { Energy conservation standards for new } \\
\text { commercial and multifamily high-rise } \\
\text { buildings; these standands are manda- } \\
\text { tory for all new federal construction } \\
\text { of this category, and voluntary for } \\
\text { all others; criteria are set for four } \\
\text { compliance paths }\end{array}$ & Practice & $\begin{array}{l}\text { Building } \\
\text { Systems }\end{array}$ & Ready now & $0-2$ years & Yes \\
\hline $\begin{array}{l}\text { Roof Research Center-- } \\
\text { a national user } \\
\text { facility (indiret } \\
\text { savings) (page C.35) }\end{array}$ & $\begin{array}{l}\text { Collection of measurement and anal- } \\
\text { ysis capabilities available to the } \\
\text { industry for solution of roof prob- } \\
\text { lems, including both thermal perfor- } \\
\text { mance and durability problems }\end{array}$ & Practice & $\begin{array}{l}\text { Building } \\
\text { Systems }\end{array}$ & Ready now & 3-5 years & Yes \\
\hline $\begin{array}{l}\text { Simplified thermal } \\
\text { analysis of roofs } \\
\text { (STAR) (indirect } \\
\text { energy savings) } \\
\text { (page C.42) }\end{array}$ & $\begin{array}{l}\text { STAR is a user-friendly PC-based } \\
\text { computer code for thermal analysis } \\
\text { of one-dimensional roof heat flow } \\
\text { problems }\end{array}$ & Practice & $\begin{array}{l}\text { Building } \\
\text { Systems }\end{array}$ & 1-2 years: & Blank & Yes \\
\hline $\begin{array}{l}\text { Large-scale climate } \\
\text { simulator (LSCS) } \\
\text { (indirect savings) } \\
\text { (page C.43) }\end{array}$ & $\begin{array}{l}\text { A climate chamber in which roofs can } \\
\text { be tested for thermal performance and } \\
\text { service life under various simulated } \\
\text { and accelerated indoor/outdoor environ- } \\
\text { mental conditions; this is a DOE } \\
\text { facility available for private-sector } \\
\text { and non-DOE groups }\end{array}$ & Equipment & $\begin{array}{l}\text { Building } \\
\text { Systems }\end{array}$ & Ready now & 6-10 years & Yes \\
\hline $\begin{array}{l}\text { Roof thermal research } \\
\text { apparatus (RTRA) } \\
\text { (does not save enrgy) } \\
\text { (page C.44) }\end{array}$ & $\begin{array}{l}\text { Outdoor facility for testing thermal } \\
\text { and moisture properties of real roof } \\
\text { reactions under field conditions; the } \\
\text { apparatus has four independent, fully } \\
\text { instrumented test stations }\end{array}$ & Equipment & $\begin{array}{l}\text { Building } \\
\text { Systems }\end{array}$ & Ready now & 3-5 years & Yes \\
\hline
\end{tabular}


Table B-3. Tools, Technologies, and Practices Almost Ready for Commercialization and Needing Assistance (continued)

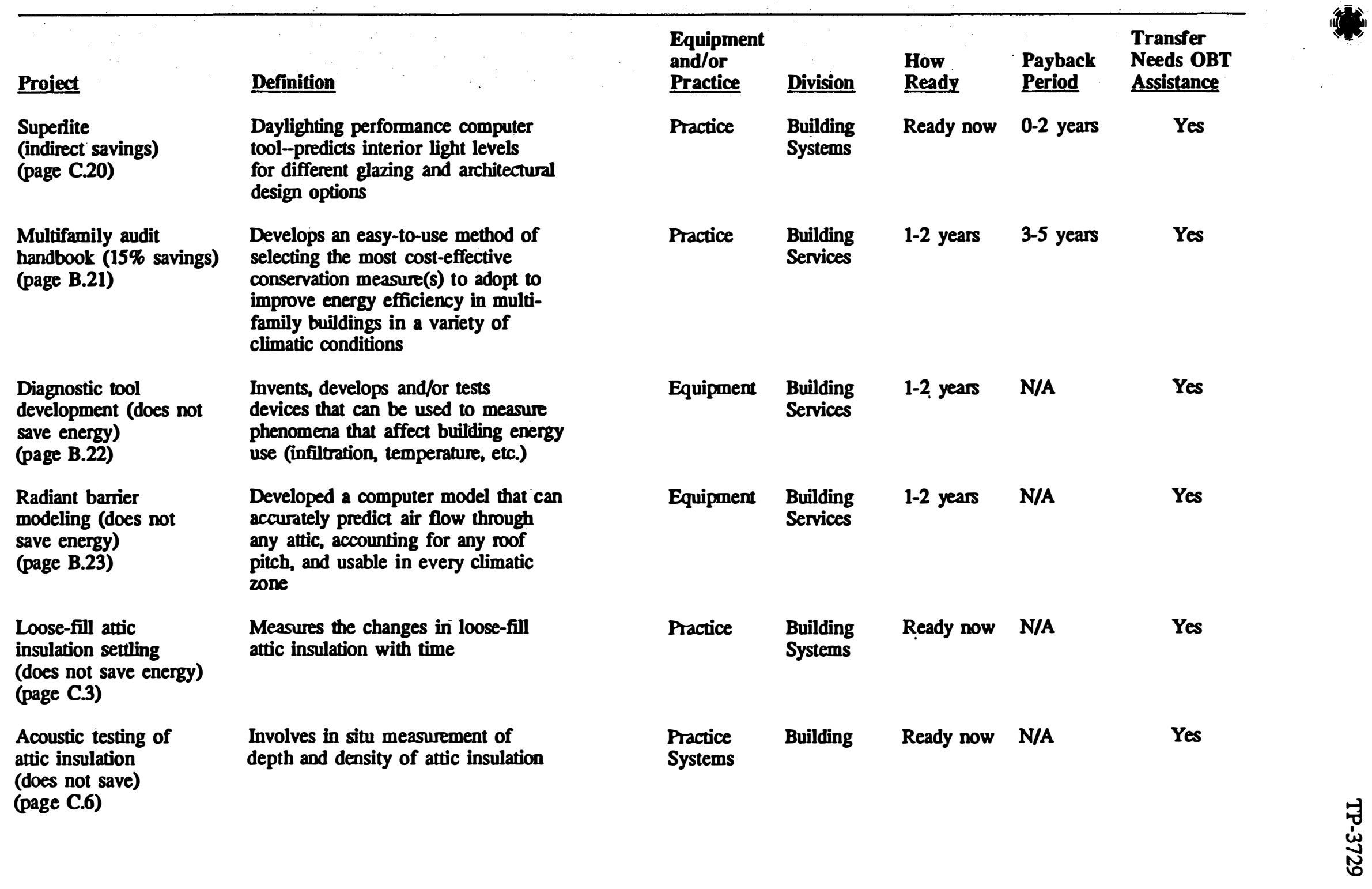


Table B-3. Tools, Technologies, and Practices Almost Ready for Commercialization and Needing Assistance (concluded)

\begin{tabular}{|c|c|c|c|c|c|c|}
\hline Project & Definition & $\begin{array}{l}\text { Equipment } \\
\text { and/or } \\
\text { Practice }\end{array}$ & Division & $\begin{array}{l}\text { How } \\
\text { Ready }\end{array}$ & $\begin{array}{l}\text { Payback } \\
\text { Period }\end{array}$ & $\begin{array}{l}\text { Transfer } \\
\text { Needs OBT } \\
\text { Assistance }\end{array}$ \\
\hline $\begin{array}{l}\text { Moisture guidelines } \\
\text { for residences } \\
\text { (indirect savings) } \\
\text { (page C.32) }\end{array}$ & $\begin{array}{l}\text { Development of construction practices } \\
\text { and novel materials that provide effec- } \\
\text { tive moisture control in building wall } \\
\text { systems }\end{array}$ & $\begin{array}{l}\text { Practice } \\
\text { Systems }\end{array}$ & Building & 1-2 years & N/A & Yes \\
\hline $\begin{array}{l}\text { Core commercial day- } \\
\text { lighting (10\% savings) } \\
\text { (page B.20) }\end{array}$ & $\begin{array}{l}\text { Develops a simple method that small- } \\
\text { business owners can use to optimize } \\
\text { lighting in their (usually rented) } \\
\text { facilities; the method will account } \\
\text { for the existing firtures and ensure } \\
\text { compatibility and efficiency }\end{array}$ & Practice & $\begin{array}{l}\text { Building } \\
\text { Services }\end{array}$ & 1-2 years & $0-2$ years & Yes \\
\hline $\begin{array}{l}\text { Energy tracking system } \\
\text { (does not save energy) } \\
\text { (page B.25) }\end{array}$ & $\begin{array}{l}\text { Developing a methodology and inexpen- } \\
\text { sive measurement devices to collect } \\
\text { energy-use information on all aspects of } \\
\text { a commercial building's energy pattems }\end{array}$ & Practice & $\begin{array}{l}\text { Building } \\
\text { Services }\end{array}$ & $1-2$ years & N/A & Yes \\
\hline $\begin{array}{l}\text { Thermal bridges } \\
\text { design catalog } \\
\text { (mdirect savings) } \\
\text { (page C.31) }\end{array}$ & $\begin{array}{l}\text { Provides design information on multi- } \\
\text { dimensional heat transfer problems in } \\
\text { buildings; this information will help } \\
\text { architects avoid condensation points } \\
\text { as well as save energy }\end{array}$ & Practice & $\begin{array}{l}\text { Building } \\
\text { Systems }\end{array}$ & 1-2 years & 3-5 years & Yes \\
\hline $\begin{array}{l}\text { Advanced residential } \\
\text { ventilation systems } \\
\text { (10\% savings) } \\
\text { (page C.27) }\end{array}$ & $\begin{array}{l}\text { Developing a controlled ventilation } \\
\text { system, which is integrated with } \\
\text { residential heating, water heating, } \\
\text { and space cooling; this will optimize } \\
\text { the use of available energy in } \\
\text { ventilation flows }\end{array}$ & Equipment & $\begin{array}{l}\text { Building } \\
\text { Systems }\end{array}$ & 1-2 years & $0-2$ years & Yes \\
\hline
\end{tabular}

Energy tracking system (does not save energy)

Thermal bridges

design catalog

(mdirect savings)

Advanced residential

(10\% savings) ventilation flows 
Table B-4. Tools, Technologies, and Practices Almost Ready for Commercialization, Not Needing Assistance

\begin{tabular}{|c|c|c|c|c|c|c|}
\hline Project & Definition & $\begin{array}{l}\text { Equipment } \\
\text { and/or } \\
\text { Practice }\end{array}$ & Division & $\begin{array}{l}\text { How } \\
\text { Ready1 }\end{array}$ & $\begin{array}{l}\text { Payback } \\
\text { Period }^{2}\end{array}$ & $\begin{array}{l}\text { Transfer } \\
\text { Needs OBT } \\
\text { Assistance }^{3}\end{array}$ \\
\hline $\begin{array}{l}\text { But meter } \\
\text { (indirect savings) } \\
\text { (page B.2) }\end{array}$ & $\begin{array}{l}\text { This is a low-cost, accurate } \\
\text { meter to measure the energy flow } \\
\text { delivered to consumers }\end{array}$ & Equipment & $\begin{array}{l}\text { Building } \\
\text { Services }\end{array}$ & 1-2 years & $0-2$ years & No \\
\hline $\begin{array}{l}\text { Friction reduction } \\
\text { additives ( } 50 \% \\
\text { savings) (page B.3) }\end{array}$ & $\begin{array}{l}\text { Being developed to enhance the flow } \\
\text { in circulating water heating systems }\end{array}$ & Equipment & $\begin{array}{l}\text { Building } \\
\text { Services }\end{array}$ & 1-2 years & N/A & No \\
\hline $\begin{array}{l}\text { Ground coupled heat } \\
\text { pumps (30\% savings) } \\
\text { (page A.9) }\end{array}$ & $\begin{array}{l}\text { Research to obtain the highest } \\
\text { performance at the lowest cost }\end{array}$ & Equipment & $\begin{array}{l}\text { Building } \\
\text { Equipment }\end{array}$ & Ready now & 3-5 years & No \\
\hline $\begin{array}{l}\text { Radiant barrier } \\
\text { climatic guide (10\% } \\
\text { savings) (page B.24) }\end{array}$ & $\begin{array}{l}\text { Devloping a method to determine the } \\
\text { applicability and benefits of radiant } \\
\text { barriers in various climatic zones }\end{array}$ & $\begin{array}{l}\text { Practice } \\
\text { Services }\end{array}$ & Building & 1-2 years & $0-2$ years & No \\
\hline $\begin{array}{l}\text { Aerated autoclave } \\
\text { concrete (50\% savings) } \\
\text { (page C.2) }\end{array}$ & $\begin{array}{l}\text { Evaluates the thermal and other } \\
\text { characteristics of lightweigtr } \\
\text { autoclave concrete }\end{array}$ & Equipment & $\begin{array}{l}\text { Building } \\
\text { Systems }\end{array}$ & Ready now & 3-5 years & No \\
\hline $\begin{array}{l}\text { Advanced durable } \\
\text { low-e coatings } \\
\text { (no savings listed) } \\
\text { (page C.21) }\end{array}$ & $\begin{array}{l}\text { Develops durable high transmissivity, } \\
\text { low-emissivity window coatings (either } \\
\text { hard low-e coatings or a protective } \\
\text { diamond-like coating to protect very } \\
\text { high performance soft coating) }\end{array}$ & $\begin{array}{l}\text { Equipment } \\
\text { Systems }\end{array}$ & Building & 1-2 years & Blank & No \\
\hline
\end{tabular}

1 Weijo, Nicholls, and Anderson (1988), Table 3.1 on page 3.2.

2 Weijo, Nicholls, and Anderson (1988), Table 3.2 on pages 3.4-3.5.

3 Based on program managers' responses to the item, "Will this equipment or practice require commercialization assistance from OBCS for it to succeed in the marketplace?" Data provided by Battelle Pacific Northwest Laboratories. 
Table B-4. Tools, Technologies, and Practices Almost Ready for Commercialization, Not Needing Assistance (continued)

\begin{tabular}{|c|c|c|c|c|c|c|}
\hline Project & Definition & $\begin{array}{l}\text { Equipment } \\
\text { and/or } \\
\text { Practice } \\
\end{array}$ & Division & $\begin{array}{l}\text { How } \\
\text { Ready }\end{array}$ & $\begin{array}{l}\text { Payback } \\
\text { Period }\end{array}$ & $\begin{array}{l}\text { Transfer } \\
\text { Needs OBT } \\
\text { Assistance }\end{array}$ \\
\hline $\begin{array}{l}\text { Multizonal infiltra- } \\
\text { tion and ventilation } \\
\text { measurement (indi- } \\
\text { rectly saves energy) } \\
\text { (page C.22) }\end{array}$ & $\begin{array}{l}\text { Developed equipment to measure air } \\
\text { movement into and between various } \\
\text { zones (rooms) of a building }\end{array}$ & Equipment & $\begin{array}{l}\text { Building } \\
\text { Systems }\end{array}$ & Ready now & N/A & No \\
\hline $\begin{array}{l}\text { Mathematical modeling } \\
\text { of indoor air quality } \\
\text { (indirect savings) } \\
\text { (page C.28) }\end{array}$ & $\begin{array}{l}\text { Developing an indoor air quality } \\
\text { model, which will allow the research } \\
\text { community to anlayze how the building } \\
\text { affects air movement }\end{array}$ & Practice & $\begin{array}{l}\text { Building } \\
\text { Systems }\end{array}$ & 1-2 years & N/A & No \\
\hline $\begin{array}{l}\text { Roof surface treat- } \\
\text { ment guidelines } \\
\text { (indirect savings) } \\
\text { (page C.37) }\end{array}$ & $\begin{array}{l}\text { A manual for roof consultants, } \\
\text { designers and contractors that pro- } \\
\text { vides specific information on the } \\
\text { roof thermal performance impact of } \\
\text { changes in surface reflectance and } \\
\text { surface mass }\end{array}$ & Practice & $\begin{array}{l}\text { Building } \\
\text { Systems }\end{array}$ & 1-2 years & 3-5 years & No \\
\hline $\begin{array}{l}\text { Field thermal perfor- } \\
\text { mance methodology } \\
\text { (indirect savings) } \\
\text { (page C.39) }\end{array}$ & $\begin{array}{l}\text { Determines the thermal performance } \\
\text { of roofs in the field; the methodol- } \\
\text { ogy is based on observation, review } \\
\text { of design drawings, a nondestructive } \\
\text { moisture survey, and field cuts }\end{array}$ & Practice & $\begin{array}{l}\text { Building } \\
\text { Systems }\end{array}$ & Ready now. & 3-5 years & No \\
\hline $\begin{array}{l}\text { Propor } \\
\text { (does not save energy) } \\
\text { (page C.41) }\end{array}$ & $\begin{array}{l}\text { Computer code for determining the } \\
\text { thermal conductivities and specific } \\
\text { heat; computed directly from field } \\
\text { measurements of temperature and heat } \\
\text { flow }\end{array}$ & Practice & $\begin{array}{l}\text { Building } \\
\text { Systems }\end{array}$ & Ready now & Blank & No \\
\hline $\begin{array}{l}\text { Radiant barrier } \\
\text { systems (10\% savings) } \\
\text { (page C.9) }\end{array}$ & $\begin{array}{l}\text { Developing a database on performance } \\
\text { characteristics of radiant barier } \\
\text { systems }\end{array}$ & Equipment & $\begin{array}{l}\text { Building } \\
\text { Systems }\end{array}$ & Ready now & $6-10$ years & No \\
\hline
\end{tabular}


Table B-4. Tools, Technologies, and Practices Almost Ready for Commercialization, Not Needing Assistance (concluded)

\begin{tabular}{|c|c|c|c|c|c|c|}
\hline Project & Definition & $\begin{array}{l}\text { Equipment } \\
\text { and/or } \\
\text { Practice } \\
\end{array}$ & Division & $\begin{array}{l}\text { How } \\
\text { Ready }\end{array}$ & $\begin{array}{l}\text { Payback } \\
\text { Period }\end{array}$ & $\begin{array}{l}\text { Transfer } \\
\text { Needs OBT } \\
\text { Assistance }\end{array}$ \\
\hline $\begin{array}{l}\text { High-R windows } \\
\text { (no savings listed) } \\
\text { (page C.18) }\end{array}$ & $\begin{array}{l}\text { Develops very high-R (over R-10) } \\
\text { window subsystems with high trans- } \\
\text { missivity, low emissivity, which will } \\
\text { perform over architectural lifetimes }\end{array}$ & Equipment & $\begin{array}{l}\text { Building } \\
\text { Systems }\end{array}$ & 1-2 years & 3-5 years & No \\
\hline $\begin{array}{l}\text { Advanced leakage } \\
\text { techniques } \\
\text { (indirect savings) } \\
\text { (page C.24) }\end{array}$ & $\begin{array}{l}\text { Developing a pulse technique where } \\
\text { leakage characteristics of buildings } \\
\text { are determined using acoustical } \\
\text { measurements }\end{array}$ & Equipment & $\begin{array}{l}\text { Building } \\
\text { Systems }\end{array}$ & 1-2 years & N/A & No \\
\hline $\begin{array}{l}\text { Foundation design } \\
\text { tools including hand } \\
\text { books (indirect } \\
\text { savings) (page C.34) }\end{array}$ & $\begin{array}{l}\text { Focused on either the architect/ } \\
\text { engineer or builder audience, which } \\
\text { provide state-of-the-art information } \\
\text { on energy efficiency foundation designs }\end{array}$ & Practice & $\begin{array}{l}\text { Building } \\
\text { Systems }\end{array}$ & Ready now & $0-2$ years & No \\
\hline $\begin{array}{l}\text { Sick building syndrome } \\
\text { protocol (indirect } \\
\text { energy savings) } \\
\text { (page C.26) }\end{array}$ & $\begin{array}{l}\text { Developing a protocol designed to } \\
\text { accurately assess buildings receiv- } \\
\text { ing air quality complaints, which } \\
\text { minimizes disruption }\end{array}$ & Practice & $\begin{array}{l}\text { Building } \\
\text { Systems }\end{array}$ & $1-2$ years & N/A. & No \\
\hline $\begin{array}{l}\text { Window } 3.1 \text { computer } \\
\text { program (does not } \\
\text { save energy) } \\
\text { (page C.19) }\end{array}$ & $\begin{array}{l}\text { A PC-based program that predicts the } \\
\text { thermal performance of windows }\end{array}$ & Practice & $\begin{array}{l}\text { Building } \\
\text { Systems }\end{array}$ & Ready now & N/A & No \\
\hline
\end{tabular}




\section{APPENDIX C \\ Transferring Building Energy Technologies by Linking Government and Private-Sector Programs}


DOE PROGRAMS 


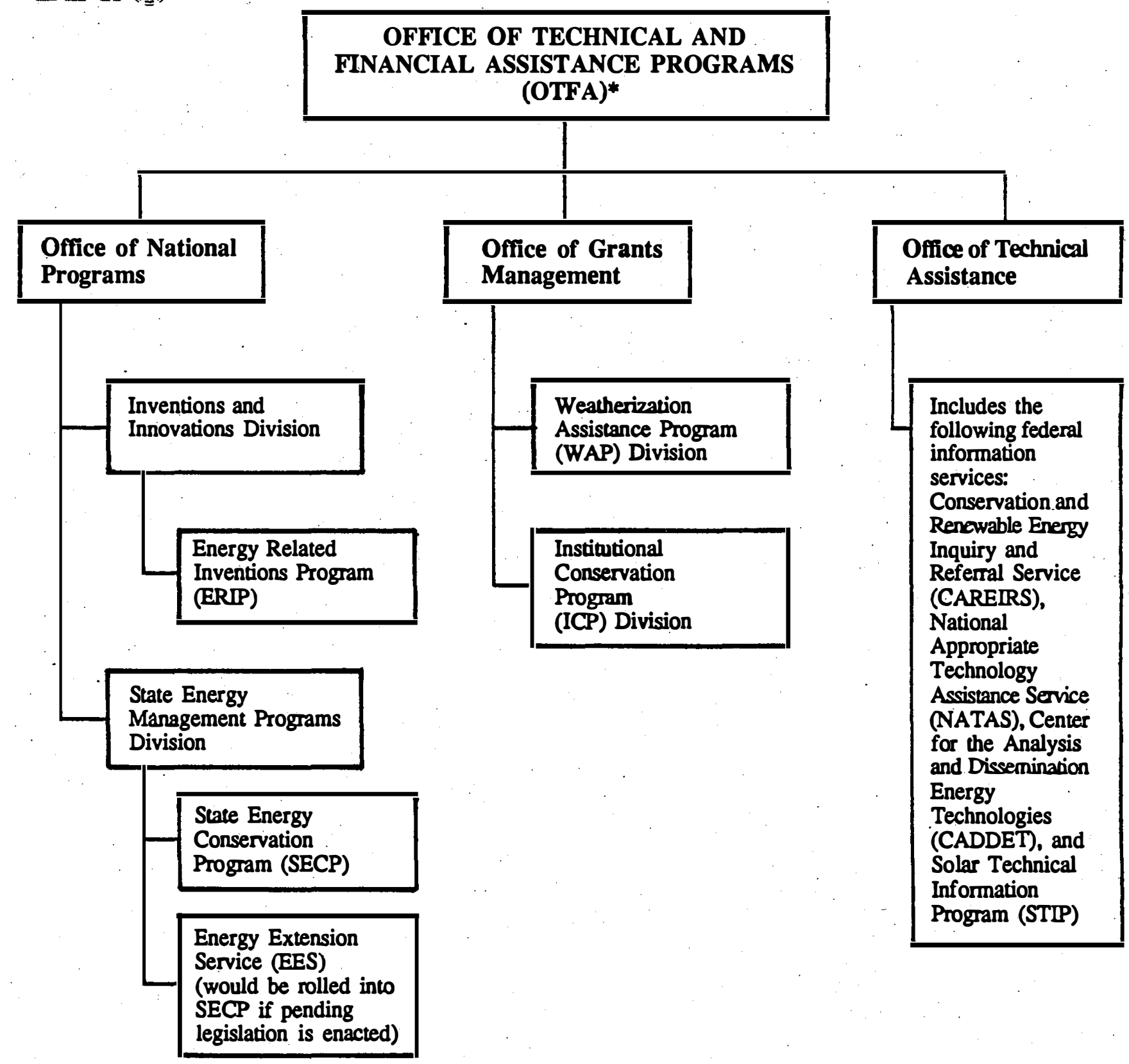

*This chart reflects the CE organization announced April 19, 1990. 


\section{OFFICE OF TECHNICAL AND FINANCIAL ASSISTANCE (OTFA)}

Name of program: Office of Technical and Financial Assistance (OTFA)

Contact person/ organization:

Audience:

Funding:

Description:

Problems:
Mr. Frank Stewart, Deputy Assistant Secretary

Office of Technical and Financial Assistance

U.S. Department of Energy

1000 Independence Ave., SW

Washington, DC 20585

(202) $586-9240$

State and local governments; private and nonprofit organizations

Under the CE reorganizaion, OTFA funding subsumes all state and local assistance programs (see descriptions of those programs)

OTFA's mission is to encourage the use of renewable energy and energy efficiency by working cooperatively with state and local governments and private and nonprofit organizations. The Office transmits technical and financial assistance from DOE and encourages active participation by the states in planning DOE programs.

Three of fices have been created that report to the Deputy Assistant Secretary for Technical and Financial Assistance. These are the Office of National Programs, the Office of Grants Management, and the Office of Technical Assistance. The Office of National Programs includes the Inventions and Innovation Division that administers the Energy Related Inventions Program (ERIP) and the State Energy Management Programs Division that administers the Energy Extension Service (EES) and the .State Energy Conservation Program (SECP). The Office of Grants Management includes the Weatherization Assistance Program (WAP) and the Institutional Conservation Program (ICP). The Office of Technical Assistance administers federal information services, including CAREIRS, NATAS, and STIP.

In the past, among other activities, OTFA has sponsored reviews of the utility commercial-energy-conservation program offerings, surveyed state/utility cooperation, assessed the marketing and design of energy programs for the elderly, developed a demand-side management (DSM) primer with EPRI, and cosponsored four national DSM conferences. OTFA staff have arranged for CE staff to present material on renewables to state program personnel at Support Office meetings. They have also participated in the Least-Cost Utility Planning (LCUP) project.

1. Harry Lane thought that "technology push" is perceived at DOE as more important in commercializing energy technologies than "demand-side pull." DOE tends to consider its job done when companies can adopt technologies, produce products, and put them in their product lines. However, companies still have to educate installers and consumers (in other words, develop a market for the product), and so on. The respective roles of govemment and the private sector are still being defined. In his view, technology transfer occurs when information goes from A to B, and B acts on the information, and the failure to focus on demand pull sometimes limits the amount of action resulting from technology transfer. 
Opportunities:

2. The technical expertise available at the national laboratories is not necessarily accessible by state energy office staffs. Where resources flow from the SEOs to the laboratories, the relationships work well. [Existing examples are Lawrence Berkeley Laboratory (LBL)/Michigan and LBL/ Wisconsin.]

1. OTFA has the mission to be a technology-transfer arm for all of CE. OTFA staff members are comfortable and experienced in the technology transfer arena with energy service delivery organizations (especially utilities and SEOs) and are eager to perform in this mission area. They have existing contacts and mailing lists.

2. State energy offices could play a valuable role in support of LCUP activities at the state level. Some scattered activity has occurred, but OTFA staff members could do more to encourage SEOs to see themselves as players and equip them to participate in Public Utility Commission (PUC) deliberations. For example, working with other DOE staff, OTFA could set up a series of demonstrations to show SEOs how best to play a role in LCUP in the states. This could be done by selected demonstration projects, case studies, or providing backup technical assistance to SEO staffs that want to work with PUCs. Also, PUCs would have to be willing to have SEO people involved, and state procedures would have to be open to SEO participation with or testimony before the PUC.

3. OTFA staff members can act as advisers to end-use-sector researchers, including building researchers, in terms of content and presentation of technical material for general audiences. OTFA is cognizant of the translation problem between researchers and user audiences and understands how to bridge the gap and tailor information specifically for those user audiences.

4. OTFA can work with energy intermediaries to encourage them to market energy technologies.

5. OTFA can help in identifying the audiences for technologies at project inception.

6. Support Offices in Boston and Chicago have recently held technologytransfer workshops with their states. They provided sessions on all the national laboratories and their capabilities. The audiences for these workshops were the economic development, energy, and environmental offices in those states.

7. A bimodal strategy can be useful. It is helpful for information users to receive the same information from two different credible sources. Both OTFA and end-use sectors have technology transfer activities that will be coordinated so that they are mutually supportive. OTFA and end-use sector staff members in buildings, utilities, transportation, and industrial processes will work together to achieve effective technology transfer. 


\title{
ENERGY RELATED INVENTIONS PROGRAM (ERIP)
}

\author{
Name of program: Energy Related Inventions Program (ERIP) \\ Contact person/ \\ organization: \\ Ray Bames \\ Inventions and Innovation Division \\ Office of Technical and Financial Assistance \\ U.S. Department of Energy \\ 1000 Independence Ave., SW \\ Washington, DC 20585
}

Audience:

Funding:

Description:

Problems:
(202) $586-1692$

[Note: Program is operated jointly with the National Institute of Standards and Technology (NIST)]

Inventors

$\$ 5$ million/year for all types of inventions

Congress established the program in 1974 to foster U.S. inventors' creative ideas. NIST performs technical evaluations and feasibility studies; DOE awards grants, holds commercialization workshops, and performs periodic program evaluations.

DOE funds NIST to review inventions submitted to the program and to recommend to DOE those that are identified as promising. DOE then funds the selected inventors for between $\$ 50,000$ and $\$ 95,000$ to take the next step in the development of the invention. NIST only recommends $3 \%-4 \%$ of the 1,000 applications that come in yearly. NIST evaluates the inventions for technical and commercial feasibility but does not perform a full market study. NIST considers whether a need exists and the invention is significant enough to meet that need. About $30 \%$ of the inventions NIST has recommended and DOE has funded have succeeded; this is considered a high rate given the rate of success for venture capital investment success. NIST also provides technical information to innovators in the ERIP program and keeps their files open so that the inventors can come back and ask for more technical assistance.

The DOE ERIP staff maintains caseloads of inventors with whom they work. ERIP staff informs inventors about the state-of-the-art of the technology area in which they are working. Projects nu from initial concept to those ready for commercialization. Some inventors are directed to SBIR, if they qualify under that program's restrictions.

The main barrier to an OBT-ERIP linkage seems to be that ERIP works with inventors in small organizations, whereas OBT works primarily with national laboratory researchers. Thus, the two programs are working to develop technologies through different types of organizations. 
Opportunities:

1. The former BCS was involved in shared funding in a small number of ERIP projects; this activity could continue under OBT auspices.

2. The former BCS provided ERIP with technical expertise in an advisory capacity. This activity also could continue with OBT. These two activities indirectly help technology transfer because they contribute to the development of energy-efficiency technologies for which commercialization is assisted through the ERIP program.

3. ERIP could help OBT-funded projects in the area of commercialization. 


\title{
STATE ENERGY CONSERVATION PROGRAM (SECP)
}

\author{
Name of program: State Energy Conservation Program (SECP) \\ Energy Extension Service (EES) \\ Contact person/ Jerry Duane \\ organization: State Energy Management Programs Division \\ Office of Technical and Financial Assistance \\ U.S. Deparment of Energy \\ 1000 Independence Ave., SW \\ Washington, DC 20585
}

(202) $586-2344$
Audience: $\quad$ State energy offices (SEOs) and their contacts with local organizations
Funding: $\quad$ SECP: $\quad \$ 9.6$ million nationwide in FY 1989
EES: $\$ 3.9$ million nationwide in FY 1989

Description: The SECP provides financial and technical assistance to states to establish and support energy conservation programs at state and local levels. Through SECP, states promote energy efficiency and reduce energy demand. SECP requires them to match $20 \%$ of federal funds received. SECP's enabling legislation requires that states develop and implement programs in five areas: lighting efficiency standards in public buildings, carpool programs, energy efficiency in procurement, thermal efficiency standards, and right-tum-on-red.

States also develop other activities linked to an overall state energy conservation goal. Emphasizing energy education and information transfer, conservation retrofits and public/private partnerships, states have established programs in agriculture, industry, transportation, education, utilities, buildings, govemment, and small business. States are permitted to use up to one-third of their SECP funds to purchase and install retrofits under certain conditions.

EES, which has been run through the state energy offices, was intended to provide information on energy conservation to the general public. EES provides tailored information and specialized technical assistance about energy conservation and the use of renewables. Through this program, the states receive financial support to assist individuals, small business owners, and local govemment officials in managing their energy usage. EES funds also require a $20 \%$ match of state funds.

Since the earliest days, program activities have evolved and broadened, but with nationwide funding at $\$ 3.9$ million, some state allocations are so small that the program can fund only one staff person.

Currently, Congress is considering consolidating EES and SECP. It may be more efficient to combine the two programs. New legislation has been proposed repealing the National Energy Extension Service Act (NEESA) and mandating its functions under SECP. The SECP and EES funding would be merged. 
Problems:

Opportunities:
1. Former OSLAP and BCS staff members have had their own mandates and tended to concentrate on their own agendas. Until the CE reorganization, no specific responsibility for coordinating ourreach efforts between OSLAP and BCS had been assigned. With the CE reorganization, greater coordination may be facilitated between the offices responsible for R\&D and those responsible for outreach.

2. Some SEOs and national laboratories have forged relationships with each other, while others have not.

1. A technology transfer arm within OTFA has been established in the Office of Technical Assistance. OTFA staff could be assigned to liaise with OBT. Information flow between OTFA and OBT could become routine.

2. An OBT staff member could be assigned to liaise with OTFA's technical assistance staff, or each OBT division could assign such a liaison responsibility. Interaction could be facilitated if OTFA had one liaison point so that OBT staff would not have to interact with each different OTFA program separately to transfer technology.

3. The SEO staff members understand building technologies and they have expertise in energy matters; some of them have advanced in-house capabilities. Some of the more sophisticated SEOs are reaching energy intermediaries, such as builders. Opportunities may exist for expanding the role of the national laboratories in supporting the SEOs. 


\section{INSTITUTIONAL CONSERVATION PROGRAM (ICP)}

Name of program: Institutional Conservation Program (ICP)

Contact person/ organization:

William Minning

Patricia Rose

Mail Stop CE-231

U.S. Department of Energy

1000 Independence Ave., SW

Washington, DC 20585

(202) $586-9645$

Audience:

State energy offices (SEOs); administrators of schools and hospitals and their professional associations

Funding:

FY 1989: \$25 million

Description:

The ICP was instituted under the National Energy Conservation Policy Act of 1978 (NECPA) (P.L. 95-619). The act provides for the federal administration of a voluntary 50/50 matching-grants program for energy audits and the purchase and installation of energy-efficiency equipment in institutional buildings.

Two major program activities have been the matching grants program for schools and hospitals and developmental projects. Most of the latter have been completed. The Schools and Hospitals program continues as the core ICP effort. More than $\$ 775$ million have been distributed to institutions to help finance conservation improvements.

Now-completed "Tier 1" projects began in 1986 to provide seed grants to SEOs to conduct innovative energy conservation projects for schools and hospitals. They used financing, information transfer, or other mechanisms and targeted either schools or hospitals. Utah, Tennessee, South Carolina, Vermont, Colorado, Ohio, Pennsylvania, New Mexico, Nebraska, Wisconsin, New York, and Oklahoma received Tier 1 project grants.

Problems:

1. The schools and hospitals administrations do not perceive energy costs as a significant enough portion of their operating budget to warrant energy efficiency investments. Fuel costs are only $3 \%$ of operating budgets; with $\mathrm{O} / \mathrm{M}$ costs, energy costs increase to $8.5 \%$. A significant issue in education currently is the fact that deferred maintenance is resulting in decayed physical plants.

2. Administrative issues preclude staff members from being innovative; also, staff members have no incentive to initiate change and may even be discouraged from doing so, even when their actions result in significant budgetary savings.

3. Functions for the different organizations of DOE are under review, and staff members will focus on reorganization issues until these are resolved. 
[Note: OBT and ICP already have some existing linkages that could aid in technology transfer:

- ICP has already worked with the former BCS program in LCUP projects at the DOE staff level.

- The Intemational Energy Agency (IEA) has a special committee, Hospital Annex, that has developed a guide for hospital administrators. OBT is already collaborating on this effort.

- OBT (Emie Freeman) funded a book on retrofitting commercial buildings.]

1. Presenters at professional meetings are needed, both DOE program managers and peers who "did it." The Association of School Business Officials, the Association of Physical Plant Administrators, and other groups are important audiences to target.

2. Magazine articles and trade journals are important vehicles for reaching these audiences.

3. If OBT and ICP could share the trade and professional associations that each is working with, efforts could be coordinated to greater effect overall.

4. ICP publishes Facts and Features, a quarterly newsletter that goes to an audience of about 1,000 that includes SEOs, DOE field offices, and association members.

6. ICP maintains publications on energy efficiency at DOE headquarters and responds to inquiries. If OBT has any publications relevant to the commercial sector, ICP could maintain and disseminate a supply.

7. OBT could hold program reviews for ICP and other OTFA staff on the R\&D program and technology-transfer efforts.

8. The annual All-States Meeting represents a significant opportunity to reach SEO staff people; attendance has reached 500, and other organizations are also represented. Emerging technologies would be of interest to this audience, along with information on technologies and products already available.

9. Perhaps the Office of Conservation and Renewable Energy (CE) could have a centralized group to coordinate focus on the technologies $\mathrm{CE}$ is developing for end users through a facilitating role. 


\section{WEATHERIZATION ASSISTANCE PROGRAM (WAP)}

Name of program: Weatherization Assistance Program (WAP)

Contact person/ Mary E. Fowler

organization: Weatherization Assistance Program

Office of Technical and Financial Assistance

U.S. Department of Energy

Forrestal Building, CE-232, 5G-023

1000 Independence Avenue, S.W.

Washington, DC 20585

(202) $586-2204$

Audience:

WAP provides services and products that assist low-income households, particularly those of the elderly and the handicapped, in reducing energy consumption and costs. The program targets single-family and multifamily dwellings, as well as mobile homes, owned or occupied by low-income persons. Through September 1988, over 4 million homes (of an estimated 22 million eligible) have been weatherized with DOE-appropriated, Low-Income Home Energy Assistance Program (LIHEAP), and petroleum violation escrow (PVE) funds.

Funding:

FY 1989 appropriations: \$161.3 million. From FY 1977 through FY 1989, WAP funding from appropriated PVE and LIHEAP funds amounted to about $\$ 4$ billion.

Description:

The WAP was established by the Energy Conservation and Production Act (ECPA) of 1976 (P.L. 94-385). It is a formula grant program: grantees (the 50 states, the District of Columbia, and 10 Indian tribes) develop plans to meet their particular noeds and circumstances which, after review and approval by DOE, are funded for implementation. Funds are allocated on the basis of a formula derived from the WAP statute. The grantees, in turn, select and fund about 1,200 subgrantee organizations (principally, community action agencies) that provide weatherization services to low-income clients. The program is administered through six DOE operations offices and 10 field offices, which review grant applications and state plans, award grants, and monitor operations.

DOE provides technical assistance to the state and local WAP levels, assisting, for example, with health and safety regulations compliance, environmental issues, and determining the most cost-effective weatherization measures for different housing types. Increasingly, the technical assistance provided is in response to needs identified by state and local WAP implementers. Recent projects of this type include assessing the most cost-effective measures for mobile homes and developing an audit for hot, humid climates.

Problems:

1. DOE/WAP maintains a list of approved measures to which new ones may be added after DOE review of their energy-efficiency performance. From the list, states select the highest priority measures for a dwelling based on relative cost effectiveness for the particular application and the legislated $\$ 1,600$ average expenditure requirement. States may assess the costs of 
training crew members to install a measure in the context of the total cost to the state program. DOE/WAP or states might not use a new, higher order technology if the installed cost (including training if necessary) is expensive.

2. Full adoption throughout the WAP system of new techniques or technology with national applicability can take a long time--possibly five years or more--depending on the cost, technical complexity, training requirements, and the experience of early WAP adopters with the product.

Opportunities:

1. WAP should be advised of the technologies and other findings that OBT produces to see what could be used in the WAP, even though full adoption throughout the WAP system can take several years.

2. Joint OBT-WAP projects can continue to focus on discrete technical problems identified by the WAP system. For example, federally supported laboratory research is helping to define the most cost-effective mobile home retrofits for cold climates (SERI) and to develop an audit for hot, humid climates (ORNL). OBT is a contributor to both projects. WAP cannot support full-scale $R \& D$ but can fund some specific technical work on discrete problems identified by WAP program implementers.

3. At times, technical needs are identified within the WAP infrastructure that WAP itself cannot address and would like to refer to OBT for research. For example, a question has arisen as to whether radiant barriers should be used as a weatherization measure. WAP will rely on OBT work to answer this question.

4. Information transfer on the mobile home work completed to date is being accomplished through the WAP annual conference, regional meetings, and articles in Home Energy and The Energy Exchange. Also, sessions have been developed to train trainers from the states in the latest results.

5. Individual state or local WAPs might be interested in serving as "test beds" for demonstrating emerging technologies from the end-use sectors, including buildings. 


\section{FEDERAL ENERGY MANAGEMENT PROGRAM (FEMP)}

Name of program: Federal Energy Management Program (FEMP)

Contact person/ organization:

Richard Brancato, Director, or Tina Van Sickle

Office of FEMP

Office of Building Technologies

U.S. Department of Energy

1000 Independence Ave., SW

Washington, DC 20585

(202) $586-5772$

Audience:

Federal government agencies, especially facilities designers, procurement officers, and facilities managers

Funding:

\$1.2 million in FY 1990, DOE appropriation; other federal agencies cost-share projects

Description: $\quad$ FEMP develops policy and regulations for energy use in the federal sector. FEMP also prepares annual reports to the President and Congress on federal energy management.

Through the national laboratories, FEMP provides technical assistance to agencies on energy conservation improvements in federal buildings, energy assessment and management techniques, and energy awareness. FEMP distributes information, publications, and software on life-cycle costing (LCC) and A Simplified Energy Analysis Method (ASEAM).

FEMP publishes a quarterly technical bulletin, FEMP Update, to promote technology transfer and report on energy management and shared energy savings initiatives.

Problems: $\quad$ 1. Although some energy experts have viewed the federal govemment role as bulk purchasing of energy efficiency and renewable technologies to promote their commercial use, there are limitations to this approach. Agency management is disaggregated such that purchasing/procurement departments cannot buy energy equipment to help the commercialization process for technologies. Each federal building is different; to acquire 10,000 heat pumps, for example, would not make sense.

2. Although LCC regulations govem major retrofit decisions, certain equipment can be omitted from these decision processes. Regulations on LCC might need improvement or stricter interpretation, such that any time an agency purchases equipment or structure, it would have to lifecycle cost the decision (similar to an LCUP approach). This would create a market to which the private sector could respond.

3. R\&D efforts conducted by cognizant conservation offices to be transferred to other agencies should be conducted in a way that those agencies can use them. One way to help ensure this is to involve federal users in their development. 
Opportunities:

1. The FEMP director described opportunities in the federal government to deploy the expertise available at the national laboratories to help the energy infrastnucture do two major things:

- Place advanced technologies in the early stages of commercialization into buildings owned by federal agencies.

- The Federal Energy Management Improvement Act (P.L. 100-615), enacted November 5, 1988, requires agencies to implement procedures to enter into shared energy savings contracts and permits agencies to use cost savings from these contracts to undertake additional energy conservation measures. One opportunity could be to use the laboratories to make/design/plan LCC-effective energy improvements. FEMP is working out mechanisms to do this.

2. Upper management has the opportunity to call for interactions among the different DOE programs to enhance conservation management and integration of activities. This would provide closer integration between FEMP and its federal government customers to help the transfer of OBT technologies.

3. FEMP could join with the General Services Administration (GSA) to offer training in energy conservation for federal facilities managers. GSA maintains training centers throughout the country and trains federal officials in all topics for which the federal government offers training. OBT could give input to GSA training courses on advanced technologies. Currently, for example, GSA is offering training in shared energy savings contracting. 


\section{SMALL BUSINESS INNOVATION RESEARCH (SBIR)}

Name of program: Small Business Innovation Research (SBIR)

Contact person/

organization:

Dr. Sam Barish

SBIR Program Manager

Code ER-16

U.S. Department of Energy

1000 Independence Ave., SW

Washington, DC 20545

Spokesperson: Mrs. Gerry Washington

(301) 353-5867

(Information provided by Mr. Ron Toms and Dr. Sam Barish)

Audience: $\quad$ Small businesses developing high-technology innovations

Funding: $\quad \$ 2.5$ million/year from CE

$1.25 \%$ of DOE's extramural research budget goes to SBIR, except for Defense programs; the total for DOE is more than $\$ 30$ million annually

Description: $\quad$ SBIR's objectives are to stimulate technological innovation; use small business to meet federal R\&D needs; increase private sector commercialization of innovations derived from federal R\&D; and foster and encourage participation by minority and disadvantaged persons in technological innovation.

Eleven agencies with an extramural R\&D budget of more than $\$ 100$ million were required to establish an SBIR program using a set-aside of a stated percentage of that budget. The percentage grew from an initial $0.2 \%$ in 1983 to $1.25 \%$ in FY 1986 through 1993.

In FY 1988, DOE received and reviewed 1,214 proposals; in FY 1989 1,543 were reviewed; and 1,171 will be reviewed in FY 1990. About 23,000 solicitations are mailed out each year.

Funding takes small businesses far enough along to develop products and processes, but not necessarily far enough to manufacture the products. By definition, the program does not deal with existing technologies, but with unproven concepts. Entrepreneurs can get a grant only if they present an innovative concept. Grants come in two phases: (1) $\$ 50,000$ to show the feasibility of the concept; (2) $\$ 500,000$ to do the principal R\&D and, in some cases, to bring the concept to the commercialization stage. The program deals with all of DOE except Defense programs. As examples of state support, New Jersey and New York are offering bridge loans to get products from the innovation stage to manufacture and marketing.

Each year about 30 topics are allocated among the technical areas in DOE in proportion to their contributions to the SBIR budget. The funds are placed in a common pool, and proposals are selected competitively for award on scientific and technical merit. 
For the FY 1990 solicitation, 30 topics were defined. For example, fossil energy has five topics and nuclear energy has four. Conservation and renewables have, together, four topics in the current solicitation (up from three last year). These are (1) consumer load management technologies, (2) instrumentation and techniques for nonelectric applications of concentrated solar energy, (3) photovoltaics research, and (4) innovative polymer materials and composites.

SBIR will only accept proposals that respond to one of the technical topics. The decision about the topics for conservation and renewables is made by the Office of the Assistant Secretary for Conservation and Renewable Energy. CE funding is calculated in the Budget Office and provided to SBIR in one lump sum.

Once awards are made, the awardee is assigned to a DOE technical program manager, who provides overall direction and guidance.

Problems:

Opportunities:
The legislation establishing SBIR (P.L. 97-219) was ambiguous on one point. Technology was supposed to be transferred. New technology is being created and transferred under program auspices, yet the entrepreneurs are not being supported to transfer other DOE technology to the extent that they could.

A mechanism could be developed to push knowledge in the direction of the SBIR awardees, such as bringing awardees into meetings or sending them program overviews involving minimal reading. (They have little time to read.) If they could absorb other ideas, their own work would be strengthened, and they could develop useful collaborations for product development and for marketing their own and related products. 
SEPI

FEDERAL

INFORMATION SERVICES 


\section{CONSERVATION AND RENEWABLE ENERGY INQUIRY AND REFERRAL SERVICE (CAREIRS)}

Name of program: Conservation and Renewable Energy Inquiry and Referral Service (CAREIRS)

Contact person/ organization:

Contractor:

Audience:

Funding:

Description:

Problems:
Ms. Elaine Guthrie, DOE Program Manager

Office of Technical Assistance

Office of Technical and Financial Assistance

U.S. Department of Energy

1000 Independence Ave., SW

Washington, DC 20585

Mr. Lawrence J. Hughes

Advanced Sciences, Inc. (ASI)

2000 North 15th Street, Suite 407

Arlington, VA 22201

(703) $243-4900$

General public

$\$ 940,000$ annually, with the current contract expiring on June 30,1991 ; funded by Renewable Energy; DOE provides all CAREIRS mailings, with an estimated value of $\$ 25,000 /$ year

CAREIRS responds to general public inquiries for conservation and renewable energy-related information. CAREIRS also provides comprehensive referral service to NATAS, OSTI, NEIC, and SERI. In the latest one-year period for which there were statistics, CAREIRS handled 55,000 inquiries (a 26\% increase over the previous year). Letters accounted for $57 \%$ and phone calls for $43 \%$ of inquiries. About 350 referrals a month were made to other organizations such as NATAS, OSTI, and STIP. About one-half to three-quarters of the inquiries that CAREIRS handles are on conservation.

CAREIRS emphasizes the development of materials appropriate for use by the general public, educators, students, libraries, and professional and trade associations. CAREIRS produces no brand or company-name information, but it references books and trade associations that do. CAREIRS has 147 factsheets in its repertoire, of which 62 were developed by CAREIRS.

The way CAREIRS decides what to propose in its publications development plan is by (1) logging requests for materials it does not have, (2) scanning the trade press for cutting-edge technologies, and (3) performing special-response research on issues.

1. If CAREIRS were advertised, its use would increase. As it stands, CAREIRS is listed in telephone directories in some locales, and in the 800 \# directory. (Occasionally, CAREIRS receives a call asking how to become a secretary or something similar regarding career development. However, a name change would be expensive, involving changes to the printing of all CAREIRS publications.) 
Opportunities:

DOE's Office of Public Affairs chose to advertise CAREIRS in October 1989 as part of Energy Awareness Week. The ads emphasized energy conservation.

2. Congress has decided to reduce FY 1990 funding for CAREIRS. OTFA is currently requesting funding support for CAREIRS to avoid possible contractor staff cuts.

3. Neither CAREIRS nor an independent contractor has been funded to conduct an evaluation of CAREIRS' effectiveness. CAREIRS does log its inquiries and referrals. (For a program that used to be funded at $\$ 6$ million annually and is currently funded at about a million dollars a year, federal investment in evaluation seems warranted.)

1. If OBT considers the energy end user to be one of its audiences or if OBT thinks providing consumer information to distributors and other product manufacturers, energy intermediaries, and energy service delivery organizations is one of its roles, then it could consider a more active role with CAREIRS. In coordination with OTFA, OBT could leverage the resource it represents with a relatively modest amount of funding.

2. OBT could earmark funding to CAREIRS (or to another independent organization) for an evaluation study of the usefulness and effectiveness of the CAREIRS approach in promoting energy conservation and the use of renewables.

3. OBT also could earmark funding for advertising of the CAREIRS service to increase its use. However, DOE's Office of Public Affairs and others would have to approve this, and OTFA would have to assess the impact on CAREIRS' capacity and funding.

4. OBT could analyze any potential overlap between CAREIRS' and SumnerRider's work with "information intermediaries" (e.g.; the trade press, the regular press, etc.) and structure coordinated efforts.

5. For a modest investment of staff time, OBT could review the CAREIRS publications development plan and could recommend factsheet, paragraph, and other information product topics that should be developed: Also, OBT staff could review conservation-related factsheets.

6. For a somewhat greater investment of staff time, OBT could prepare camera-ready factsheets, such as the one OBT is producing on radiant barriers, for reproduction and distribution by CAREIRS.

7. If OBT provided resources for quantities of publications, such as technical information guides (TIGs), CAREIRS could disseminate them. (For example, at least one of the SERI-produced TIGs was aimed at "anyone interested in energy conservation。") 


\section{NATIONAL APPROPRIATE TECHNOLOGY ASSISTANCE SERVICE (NATAS)}

Name of program: National Appropriate Technology Assistance Service (NATAS)

Contact person/ organization:

Contractor:

Audience:

Funding:

Description:
Anita Dean DeVine, DOE Program Manager

Office of Technical Assistance

Office of Technical and Financial Assistance

U.S. Department of Energy

1000 Independence Ave., SW

Washington, DC 20585

(202) $586-1265$

Jeff Birkby

P.O. Box 2525

Butte, MT 59702

$1-800-428-2525$

Individuals, homeowners, state/local energy managers, small businesses, energy innovators, farmers, architects, builders, educational institutions, and nonprofit organizations

\section{\$1.4 million in FY 1990}

NATAS provides information services and technical assistance with the implementation of energy efficiency and renewable energy technologies. NATAS responds to inquiries in several ways including: (1) immediate response to requests for technical information, (2) copies of relevant articles, (3) bibliographic listings, (4) referrals to other resources, and (5) detailed answers to specific technical questions.

About 29\% of NATAS's queries concern buildings, and another 25\% concem HVAC equipment, totaling more than one-half (54\%) of NATAS queries on OBT-related energy conservation topics.

NATAS has developed four publications to respond to frequently asked questions: Combustion Appliances in Energy Efficient Homes, Combustion Heating Systems, Energy Efficient Windows, and Insulation. NATAS also maintains a collection of documents from a wide range of sources including magazine articles, product lists, and publications of state and federal govemments. These documents are distributed to users as appropriate.

NATAS applies its business expertise to energy projects and small businesses. For example, NATAS will map marketing strategies for energy-related inventions. It will assess a weatherization company's business plan. It answers questions on innovative financing or suggests specific financing options for hospitals, municipalities, and others. 
Among other NATAS services are providing brochures about its services for distribution by other organizations or directly distributing these brochures using an organization's mailing lists.

NATAS also develops articles on conservation and renewable topics for inclusion in newsletters, mailings, and magazines.

Problems:

1. NATAS has a need for the latest information from OBT on saving energy in commercial buildings, cursently a hot topic.

2. In general, NATAS neods to know when technologies and practices are ready to go on the market; e.g., they are tested, and they are known to perform. They need to know the cutting edge technologically.

3. NATAS staff members have contacts with the energy research community; however, DOE program management would like a means of staying abreast of what DOE sees as the most promising buildings energy-efficiency technologies in the pipeline.

Opportunities:

1. NATAS staff members publicize their program by looking for subjects to write articles on, and placing them in such magarines such as Popular Mechanics and Practical Homeowner. If a new or nearly new technology is being introduced, briefing the NATAS staff would be advantageous. NATAS has writers and editors. The DOE program manager would be willing to be a broker in this process.

2. DOE has funded an evaluation of NATAS by Northwestem University, through ORNL. Although estimating energy savings from a program like NATAS was difficult, the overall findings were that users liked the service. NATAS logs its contacts and sends out a form with its responses. NATAS gets back $35 \%$ of the forms and uses them to maintain quality control. No funding is currently available for evaluation. 


\title{
SOLAR TECHNICAL INFORMATION PROGRAM
}

\author{
Name of program: Solar Technical Information Program (STIP) \\ Contact person/ \\ Paul Notari \\ organization: \\ Solar Energy Research Institute (SERI) \\ 1617 Cole Boulevard \\ Golden, CO 80401
}

(303) 231-1317

\begin{abstract}
Audience:
Scientific, industrial, federal, local, and state govemment entities

Funding:

Approximately $\$ 1.3$ million annually from the former Office of Renewable Energy; neither the former Office of Conservation nor the former BCS funded STIP; however, Conservation and BCS had been funding SERI at approximately $\$ 200,000 /$ year to produce publications
\end{abstract}

\section{Description:}

STIP's purpose is to provide technical information, related to renewable energy research and technologies sponsored by DOE, to scientific, industrial, and publicsector audiences. STIP emphasizes packaging accurate, current technical information in concise form tailored for the intended audiences.

STIP fulfills two major functions:

1. Developing technical information products (periodicals, publications, exhibits, and reference works) on solar energy $R \& D$ and on energy conservation technologies and programs. The majority of STIP's funding-about $\$ 1.1$ million--is used for this function.

2. Operating the Technical Inquiry Service (TIS), an inquiry response service related to solar and conservation research funded by DOE. TIS serves the scientific, industrial, business, and public sector communities, providing definitive responses to technical questions. In addition, TIS refers general public and nontechnical inquiries to NATAS, CAREIRS, and SEOs. TIS responds to about 260 inquiries each month and handles about 175 of these itself, referring the balance to other services. Currently, approximately $15 \%$ of inquiries handled directly by TIS deal with conservation topics. About $12 \%$ of STIP funding, or $\$ 160,000$ aninually, supports TIS activities.

Problems:

Where do technical questions on conservation go? TIS responds to about 30 technical requests on conservation topics each month. Most general public and nontechnical inquiries are referred to CAREIRS or NATAS. SERI has no hotline funding and has not widely advertised its services.

Opportunities: 1. Questions dealing with renewable energy and those associated with conservation frequently overlap. Often, the appropriate response to a question on applications of renewable energy is to recommend a conservation strategy. Thus, TIS already is serving "conservation audiences" to some degree. With modest additional support, TIS could more widely announce its services and expand the scope of topics covered to include a larger spectrum of conservation subjects, continuing to focus on technical questions and assistance beyond that provided by CAREIRS and NATAS. 
2. STIP, except for the TIS activity, is primarily responsible for the preparation of technical publications and research summaries. OBT already uses some of these capabilities and it could expand this use. 


\title{
FEDERAL LABORATORY CONSORTIUM (FLC)
}

\author{
Name of program: Federal Laboratory Consortium (FLC) for Technology Transfer \\ Contact person/ \\ organization: \\ Mr. Del M. DeLabarre \\ FLC Administrator \\ Federal Laboratory Consortium \\ 224 West Washington \\ P. O. Box 545 \\ Sequim, WA 98382-0545
}

(206) 683-1828

Audience:

FLC audiences are primarily the private sector, state and local govemments, universities, and member laboratories and agencies. The FLC also supports the technology transfer needs of multiplier groups representing small businesses, industry, and state and local govemments.

FLC provides direct services to its $500+$ member R\&D laboratories and centers representing 14 agencies, particularly the technology transfer professionals at those laboratories. DOE and DOD have major member representation.

Funding:

Approximately $\$ 1.3$ million/year from its member agencies

Description:

FLC's principal purpose is to facilitate technology transfer from federal laboratories to industry, state and local govemments, and other organizations through a coordinated program for member organizations and their potential collaborators.

FLC provides a variety of services to the laboratories, including training on technology transfer, technology transfer conferences with industry, demonstration programs, exhibits, and so on. Member laboratory representatives have the opportunity to be linked via an electronic mail (E-Mail) system.

FLC's main information service is formal networking--the linking of users and federal laboratory staffs. FLC maintains a Clearinghouse and an intemal resource directory/database that lists laboratories by their technological and scientific expertise and resources. Through the Clearinghouse, a technical inquiry can be disseminated to all of those laboratories having specific expertise in the subject, via E-mail or regular mail. Or, an inquirer might receive a list of all those laboratories along with a contact [generally, the Office of Research and Technology Application (ORTA)] for each one.

FLC News is the organization's monthly newsletter. Other publications are released through NTIS. Selected special publications, such as Putting Technology to Work, are issued periodically.

Problems: $\quad$ No particular barriers to stronger ties between BCS and the FLC were identified. A more "proactive" FLC role with regard to the BCS program would require expenditure of resources. 
Opportunities:

1. OBT could take advantage of this network and referral service by ensuring that all of the laboratories participating in the OBT R\&D effort are properly represented in the FLC Clearinghouse database and in FLC publications.

2. OBT could advertise the availability of this resource to its program managers and principal investigators.

3. OBT could ensure that its technology-transfer program is highlighted occasionally at the semiannual FLC meetings by presenting speakers and perhaps other materials.

4. OBT could mention the FLC network and Clearinghouse in appropriate OBT publications as a technical assistance resource on energy efficiency technologies for buildings.

These opportunities are low in cost, yet they link OBT into an existing technology-transfer network that showcases the capabilities of the national laboratories. 
SEN 눌

\section{OTHER}

FEDERAL PROGRAMS 


\title{
HUD PUBLIC HOUSING
}

\author{
Name of program: HUD Public Housing \\ Contact person/ \\ organization \\ Nancy Chisholm \\ Department of Housing and Urban Development \\ Office of Public and Indian Housing \\ 451 Seventh St., SW \\ Washington, DC 20410
}

(202) $755-6713$

Audience:

Public housing authorities (PHAs). More than 3,000 PHAs nationwide administer the public housing program, with 11,000 public housing projects, more than 1.3 million housing units, and more than 3 million occupants.

Funding:

The Budget Authority (BA) for FY 1988 for public housing was $\$ 2.6$ billion involving 1200 staff years. The program falls under the direction of the Assistant Secretary of Public and Indian Housing.

LBL was the lead laboratory to work on federally assisted housing starting in FY 1985. LBL received \$25,000 to do some work on this in FY 1986.

Description:

HUD spends $\$ 1$ billion/year for utilities in public housing projects that use twice as much energy as private sector housing. About $\$ 750$ million to $\$ 800$ million is for energy; the balance is for water. The nation could save up to $\$ 500$ million a year if we just put public housing at the same level as private sector housing, with a four-year payback on improvements.

The housing authorities invested $\$ 0.75$ billion of HUD modemization funds in energy conservation improvements during the Reagan administration. In 1985, an Abt study found that $\$ 1$ billion in energy conservation needed to be done. Several billion dollars a year need to be spent in basic modemization.

One place to get the money is the private sector. HUD public housing officials are attempting to forge linkages between the energy service companies (ESCOs) and public housing authorities (PHAs) so that performance contracting will occur. The Affordable Comfort Conference is one of the ways that HUD hopes to reach these audiences. Officials are also working with utilities to implement shared savings arrangements with PHAs.

In the early 1980s, the PHAs were allowed to keep part of the savings from energy conservation retrofits paid for by HUD plus an added incentive at the beginning: overall, they got $1^{1 / 2}$ times a year's savings and HUD got the rest, which was the major benefit. Under the 3-year rolling base accounting system, the average spending of 3 prior years is the baseline. Any major savings achieved 3 years ago would be dropped out. Then the PHA must maintain that level of efficiency to keep up. A 1987 amendment to Section 118 suspended the rolling base and said that the PHA could keep $100 \%$ of the savings to pay off the energy service company under a performance contract using nonfederal funds [Note: these funds could include Community Development Block Grant (CDBG) funds that, once they were tumed over to cities, are considered local funds.] HUD will regulate what the PHAs do with the rest of the savings, including what proportion of it they can keep and what they can use it for. For example, they might use the extra savings to pay back the energy service 
company faster, or they might be permitted to develop something for tenants. These recent provisions make PHA's' investment in energy conservation more desirable.

HUD is working with the American Gas Association and Edison Electric Institute to get technical support from local companies to the PHAs.

Problems:

1. No absolute standard exists as to how much consumption should be. If there were a standard, a way would exist to get out of the problem posed by the performance funding system, from HUD's viewpoint.

2. Community Development Block Grant (CDBG) funds amounted to $\$ 2.9$ billion in FY 1988. However, the idea came along after CDBG came into existence that cities needed some technical assistance in deciding how to use the CDBG funds. Grants to special groups and technical assistance came from the Secretary's discretionary funds. HUD Secretary Jack Kemp's first initiative, however, was to do away with discretionary funds. There will be some technical assistance funding, but it will be released by RFP published in the Federal Register.

Opportunities:

1. HUD could assist by promoting technical assistance for energy efficiency in public housing. HUD officials said that someone within HUD needs to take this on as a cause, it would be a full-time job. A HUD "energy champion" would play a broker role, facilitating local partnerships with nonprofit organizations, utilities, and housing authorities.

2. HUD said OBT could assist in the following ways:

- Inventory what things should be considered, key technological advances that should be used.

- Prepare materials about how to save energy.

- Provide expert review of HUD proposals for housing authorities to pay off capital improvement costs on energy.

- Attend conferences and meetings with the key players in the field of federally assisted housing.

- Conduct research on the durability of improvements that have already been done in HUD public housing.

- Give reports and sponsor panel discussions.

- Set up training for HUD offices, on topics such as audits. In addition, HUD and PHA staffs need training on shared savings deals; ESCOs need training about PHAs and how to select ones with whom they can work effectively. Perhaps HUD staff members could attend GSA training on performance contracting. 
- Distribute software that Lawrence Berkeley Laboratory (LBL) has developed to help PHAs analyze their utility expenses. The distribution of this software could be explored, and more distribution could be done, if the market is not saturated.

- Work through trade associations: (1) the National Association of Housing and Redevelopment Officials (NAHRO), which has regional chapters with regular programs and a conference one or two times a year (a workshop could be held at each conference); and (2) the Council of Large Public Housing Authorities (CLPHA). Somebody has to explain to the PHAs how to use ASEAM and other tools to assess energy conservation.

- Provide a resource on technical information to PHAs about what measures are available and which ones to use; HUD can inform them that high efficiency boilers exist, but the PHA has to find a contractor who carries them. They can call NATAS, but they need a combination of advice, perhaps beyond what NATAS can tell them.

3. More facilitation between OBT and.HUD is needed to explore the opportunity to expand the use of energy-efficiency technologies in public housing. A team effort between OBT and HUD might be possible. 


\section{OTHER HUD PROGRAMS}

Name of program: Listed below

Contact person/

Robert P. Groberg

organization

Director, Energy Division

Office of Environment and Energy

U.S. Department of Housing and Uiban Development (HUD)

451 Seventh St., SW

Washington, DC 20410

(202) 755-5504

Mr. Groberg suggested that opportunities for improving energy efficiency in the nation's buildings through the use of OBT technologies might be enhanced through the other HUD programs. The audiences, funding problems, and opportunities attendant upon each of these programs would have to be explored in more depth in the future, including the perceptions of other HUD officials about the potential for realizing energy efficiency within these HUD programs.

In general, however, HUD programs other than public housing affect approximately 4 million units. Programs for assisted housing (items 2 and 3 below) involve $\$ 500$ million to $\$ 1$ billion in utility costs annually. In addition, each year $\$ 1$ billion and more are spent in Community Development Block Grants and Rental Rehabilitation Grants that are used for rehabilitating buildings.

The other HUD programs fall into six categories under three organizational units as follows.

Assistant Secretary for Housing-Federal Housing Commissioner:

1. Insurance Programs for Mortgages and Loans

2. Direct Loans

3. Subsidized Housing

Assistant Secretary for Community Planning and Development:

4. Community Development Block Grants

5. Rehabilitation Assistance Program

6. President, Government National Mortgage Association (GNMA).

These programs represent the greatest potential for energy efficiency in terms of size and possible points of leverage; however, other HUD programs may offer energy-efficiency advantages as well.

\section{Insurance Programs for Mortgages and Loans}

A. Home Improvement Insurance/Manufactured Housing. Title I insurance on home improvements and manufactured housing: \$4.3 billion Title I loans currently insured $(93,000$ new loans, 77,000 of them for property improvements and 16,000 for manufactured homes). $\$ 914$ million in commitments were issued for this insurance during FY 1988; 210 staff years were spent in the program. 
B. Mortgage Insurance for Multifamily Properties. Mortgage insurance for multi-family dwellings: 1.9 million units are currently insured; in FY 1988 87,000 units were insured at $\$ 3.07$ billion; 1,030 staff years in the program. HUD also acquires multifamily projects or housing units through mortgage defaults.

C. Mortgage Insurance for Single Family. Mortgage insurance to 1-4 unit homes: 6.5 million homeowners currently have FHA-insured mortgages; 945,000 applications from prospective buyers were received in FY 1988; 2,280 staff years in the program.

D. "HUD Homes." Single-family property disposition: HUD generally sells repossessed homes as is (no improvements). In FY 1988, there were 86,000 acquisitions and 81,000 sales. Proceeds were $\$ 3$ billion, which.went back into the FHA fund; 850 staff years in the program.

\section{Direct Loans: Housing for Elderly and Handicapped}

Direct loans for the elderly; in FY 1988, 11,000 new units were funded; 3,500 loans are now in HUD's portfolio; $\$ 565$ million in loans were made. Since $1959,224,000$ units have been constructed or rehabilitated, $\$ 9.5$ billion has been loaned, and 430 staff years were spent in the program.

\section{Subsidized Housing}

A. Section 8 Lower Income Rental Assistance and Housing Voucher Program. Aids lowand very low income families in obtaining clean, safe, and sanitary housing in private accommodations. Tenants pay the highest of $30 \%$ of adjusted income, $10 \%$ of gross income, or the portion of welfare assistance designated to meet housing costs. The housing must meet HUD standards and fall within the range of fair market rents as determined by HUD. Section 8 subsidized housing provides certificates and vouchers to 2.24 million households living in privately owned housing. About one-half of these units are also aided by HUD (such as Section 236 housing and housing for the elderly). During FY 1988, \$9 billion in subsidies were provided, with commitments for 5 years; 525 staff years were spent in the program.

B. Management of Privately Owned Subsidized Housing. Approximately 6,500 projects involving more than 650,000 units were subject to HUD requirements for performing energy surveys, preparing energy conservation plans, and implementing energy conservation measures. At a minimum, HUD required an owner certification that cost-effective measures have been taken to reduce utility expenses. These 6,500 projects are required to secure HUD approval for requested rent increases. HUD could take the opportunity of periodic rent increase requests to ensure that owners are complying with the energy provisions of existing laws. Also, DOE could provide technical assistance to HUD in developing effective, user-friendly methods of choosing the best retrofits for any specific building.

\section{Community Development Block Grants}

Funding is $\$ 2.9$ billion/year. Approximately 850 cities with populations over 50,000 are "entitlement cities" and receive $70 \%$ of CDBG funds directly. About 720 cities with populations under 50,000 receive funding through their states by competition. Energy efficiency is currently an objective of the CDBG program, but it is not a funding requirement. Approximately one-third of the annual funding is used for property rehabilitation. Approximately 22\% of CDBG funding used for property rehabilitation went to multifamily housing. Among CDBG cities, the variety of standards and codes could be a barrier to implementing energy efficiency through the program. An opportunity could exist in the area of district heating and cooling projects. 


\section{Rehabilitation Assistance Programs}

Other rehabilitation assistance programs include the Rental Rehabilitation Program, Section 312 Low-Interest Loan Program, Urban Homesteading Program (Section 810), and the Homeless Assistance Program (McKinney Act). Nationwide cooperation with DOE's Weatherization Assistance Program occurs only on an ad hoc basis, although an opportunity may exist for cooperation at the local level. DOE could provide improved audit techniques, technical assistance in creative financing, educational materials for property owners and program staff, and manuals and handbooks.

\section{Government National Mortgage Association (GNMA-" Ginnie Mae")}

GNMA guarantees payments on securities that private lenders issue; pools loans of FHA and VA and enables them to sell to investors so capital goes back into the housing market. The purpose of this program is to attract nontraditional investors into the residential mortgage market by offering high-yield, risk-free, govemment-guaranteed securities without the servicing obligations of a mortgage loan portfolio. $\$ 333$ billion is in outstanding guaranteed securities; $\$ 57$ billion in guarantees were issued in FY 1988; 50 staff years in the program.

GNMA is rying to encourage special treatment for energy efficiency in mortgages, which is related to interest in home energy rating systems.

\section{Summary}

DOE has the capability to support HUD in developing and implementing conservation and renewable energy activities. DOE can assist HUD programs in incorporating energy efficiency and renewables measures, performing energy surveys and audits, providing training in shared energy savings and other relevant matters, monitoring program effectiveness, and developing standards.

Follow-up discussions and further definition of areas of opportunity by the cognizant HUD and DOE program managers are needed if the significant energy-efficiency potential thus far identified within HUD's programs is to be realized. 


\title{
NATIONAL INSTITUTE OF STANDARDS AND TECHNOLOGY (NIST)
}

\author{
Name of program: Office of Technology Commercialization (OTC) \\ Contact person/ \\ organization: \\ Robert Chapman, Acting Director \\ Office of Technology Commercialization \\ National Institute of Standards and Technology \\ Gaithersburg, MD 20899
}

(301) $975-2723$

Fax: (301) 975-2128

Audience: $\quad$ U.S. industry

Funding: $\quad$ Total OTC funding in FY 1990 is approximately $\$ 3$ million. About $40 \%$ of NIST funding comes from other govemment agencies; with approximately 500 to 600 contracts. Major contractors are NASA, DOD, and DOE. About 100 agencies are involved, including the Environmental Protection Agency (EPA), the Department of Health and Human Services (HHS), the U.S. Postal Service (USPS), and the National Research Council (NRC). Approximately 5\% to 10\% of the NIST budget comes from fees for services. For example, NIST sells standard reference materials and has calibration and laboratory accreditation services. About one-half of NIST's budget is from Congressional appropriations.

Description: $\quad$ OTC is currently doing the following:

- Surveying what NIST is doing that may have potential for industry.

- Letting industry know that it exists.

- $\quad$ Getting industry to use it.

- Working cooperatively with other organizations that are making technologies known to users (e.g., both federal and nonfederal).

The Omnibus Trade and Competitiveness Act of 1988 changed the agency's name from National Bureau of Standards (NBS) to NIST and gave the agency a new set of mandares:

- Survey the states to discover how they are using technology as part of an economic development program. This survey identified about 230 organizations spending \$620 million/year on economic development programs. The survey asked how technologies are used. Some of the patterns discovered include incubator facilities, centers of excellence at universities, and methods of engineering extension education.

- Hold a series of workshops in the states to inform them about federal resources. The state people needing to attend these workshops are located in a variety of organizations. For example, Virginia has a Center for Innovative Technology. Ohio has the Ohio Technology Transfer Organization (OTTO), which is part of the larger Thomas Edison program. Pennsylvania has a Technical Assistance Program under Pennsylvania State College, which is part of the Ben Franklin partnership.

- Develop an Advanced Technology Program to accelerate the commercialization of new manufacturing techniques by U.S. business, particularly by small entrepreneurial firms. 
Problems:

Opportunities:
- Expand the Energy Related Inventions Program (ERIP) (see the description of that program) from simply energy inventions to all inventions, with the exception of frivolous things like toys and cosmetics. Recommendations about this expansion have gone back to Congress via the Department of Commerce (DOC).

- Expand user-oriented industrial services, such as national standard reference data and materials.

1. No one industry has the resources to solve technology commercialization problems alone, and the federal government can seed projects to tackle these problems; industry could eventually take over. Antitrust laws might have to be relaxed so that industries can work together.

2. NIST-OTC has not yet completed an evaluation of how OBT could assist in its mission to improve the competitiveness of U.S. industry, both in terms of (1). providing innovative technology, which would create new business opportunities, and (2) improving the productivity of the manufacturing sector through reducing energy operating costs.

1. NIST has good rapport with industry; it sets standards and has credibility; it appears to be good at transferring technological information. Working with NIST to transfer energy-efficient technologies through economic development organizations at the state level, and possibly to link state energy offices with state economic development offices, could be a prime opportunity.

2. The OTC has an annual budget of $\$ 1.3$ million earmarked for technology extension, including workshops, seminars, and grants to states to foster technology commercialization and economic development.

3. The OTC has signed a memorandum of agreement with the Federal Laboratory Consoroium (FLC) (see the description of the FLC) to reach out to businesses and conduct workshops for state technical and economic development organizations. The FLC will inform state people about how to gain access to the federal laboratories. At these workshops, building energy materials could be available for display and distribution.

4. The OTC operates a clearinghouse on state and local initiatives, in cooperation with the DOC's technology administration, through its State Technology Extension Program. The OTC could train the trainers of the state extension staffs on where to get information on energy-efficient technologies.

5. Ties already exist with NIST through the Center for Building Technologies (see the description of that program). OBT could undertake a pilot project to explore the feasibility of such a linkage between OBT and the NIST OTC. 


\title{
NATIONAL INSTITUTE OF STANDARDS AND TECHNOLOGY (NIST)
}

\author{
Name of program: Center for Building Technology (CBT) \\ Contact person/ \\ organization: \\ James E. Hill, Chief \\ Building Environment Division \\ Center for Building Technology \\ National Institute for Standards and Technology \\ Gaithersburg, MD 20899
}

\begin{abstract}
Audience: $\quad$ - ASHRAE and ASTM, consensus standards
- $\quad$ Researcher exchange program, with approximately 10 industry-paid staff members from industry on site at a time

- $\quad$ Product manufacturers

Funding: $\quad \$ 11$ million/year, 112 staff members

Description: The CBT's mission is to increase the usefulness, safety, and economy of buildings through the advancement of building technology and its application to the improvement of building practices. Its objectives are to
\end{abstract}

1. Increase the productivity and safety of building construction by providing technical bases for improved structural and earthquake design criteria. (Examples: structural loads, wind engineering, structural analysis, nondestructive evaluation methods, full-scale structural performance, failure analysis and investigation, earthquake engineering.)

2. Reduce building costs and increase building quality by providing technical bases for selecting the most cost-effective materials. (Examples: protective coatings, performance of roofing systems, service life prediction, quality assurance of laboratories, cement hydration.)

3. Reduce the cost of designing and operating buildings and increase the international competitiveness of the U.S. building industry by providing modeling, measurement, and test methods needed to (1) use advanced computation and automation effectively in construction, (2) improve the quality of the indoor environment, and (3) improve the performance of building equipment. (Examples: refrigerant mixtures, mechanical systems and controls, test procedures for energy appliances, indoor air quality, heat transfer, solar equipment, computer-integrated construction, lighting, building security.)

Problems:

NIST has no direct plan to assist U.S. industry other than through its programs. NIST has developed a reorganization plan and has not yet put it into effect. (A search for a new director is currently under way.) The Office of Technology Commercialization is planning how to carry out NIST's new legislative mandates. 
Opportunities:
1. CBT works with ASHRAE and ASTM, as do other OBT-funded groups and national laboratories. CBT staff members write chapters for the ASHRAE Handbook of Fundamentals. In this regard, they are already carrying out a technology transfer function for OBT.

2. The National Research Council of Canada in Ottawa produces a periodical, the Canadian Building Digest, that Dr. Hill thinks is extremely useful to practitioners in Canada. It publishes the viewpoint of the local builder, and it synthesizes the research and translates it for the general contractor, giving practical guidance on what to do.

3. The CBT Building Technology Symposia series has been running for 17 to 18 years, with eight or nine symposia/year. Started originally for federal agencies, the free symposia are one-day presentations on state-of-the-art technologies in particular areas. Past topics have included

- Experiences of federal agencies with computer graphic systems

- Application of artificial intelligence to construction

- Advances in painting technology and practice

- Building security

- Earth orbiting structures

- Moisture research problems in buildings

- Design of structures for explosive threats

- Diagnostics and maintenance of mechanical systems in buildings.

Between 50 and 200 people attend; most of them are federal agency staff members. CBT maintains. a mailing list to announce the seminars. Volunteer staff time is used to organize the seminars, but with a small amount of funding and some work with the laboratories, the symposium series could be increased in significance. OBT might want to explore whether the attendees at these seminars are decision makers in their respective organizations, actually affecting building design or other ways in which energy is used. 


\title{
NATIONAL ASSOCIATION OF REGULATORY UTILITY COMMISSIONERS (NARUC)
}

\author{
Name of program: National Association of Regulatory Utility Commissioners \\ (NARUC) \\ Contact person/ \\ organization: \\ Michael Foley \\ Director of Financial Analysis \\ National Association of Regulatory Utility Commissioners \\ 1102 ICC Building \\ Constitution and 12th, NW \\ P. O. Box 684 \\ Washington, DC 20044-0684
}

Audience:

Funding:

Description:

Problems:
(202) $898-2200$

NARUC membership includes 220 state public utility commissioners plus 100 Canadian and federal officials. The commissioners regulate, in addition to utility companies, telephone, water, gas, insurance, banking, and taxicab industries.

NARUC's budget comes from member utility commissions. The federal government provides office space in lieu of dues from federal commissioners. BCS funds NARUC's Least-Cost Utility Planning (LCUP) project at $\$ 135,000 /$ year.

NARUC serves as the commissioners' eyes and ears in Washington, D.C., keeping them abreast of bills; rules, and regulations being developed in the capitol and representing their interest on Capitol Hill and in the courts.

NARUC also serves as a source of information for the commissioners through its newsletter, annual conferences, and special conferences.

NARUC committees also develop commission policies on an array of topics. For example, the Energy Conservation Committee develops NARUC policy in the energy conservation arena and presents resolutions to the full membership. The committee's membership includes 20 commissioners and 25 staff people. The committee chair is Mary Lou Munts of the Wisconsin Public Service Commission, and the cochairs of the staff group are Rick Morgan (District of Columbia Public Service Commission) and Mary Kilmarx (Rhode Island Public Utilities Commission).

1. Utility regulation involves complex issues, and commissioners have a difficult time staying abreast of the technical information they need. Since most commissioners serve for only $\mathbf{4}$ years, this compounds the problem.

2. An inspiring speaker like Amory Lovins might give a brilliant presentation, but afterward, the commissioners are unsure about what to do next. They lack specific information about, for example, the names of the manufacturers of energy-efficient light bulbs, where these can be obtained, and whether people will use them. The same is true of advanced windows and the other energy-efficiency technologies. 
Opportunities:

1. NARUC publishes a weekly Bulletin for which timely, brief articles could be prepared on energy efficiency in buildings, utility regulation to foster energy efficiency, and related topics.

2. Each year, NARUC sponsors a winter meeting in Washington the last week of February, a summer meeting on the West Coast the third week of July, and an annual convention that travels in November. In addition, NARUC's five regional groups (Northeast, New England, Westem, MidAmerica, and Southeastem) meet once a year in the late spring. Each of these meetings could be a venue for speakers on energy efficiency in buildings and how commissioners can affect its use.

3. DOE could provide information to the Energy Conservation Committee that would help in the debate among commissioners about the best ways to solve energy problems.

In summary, the NARUC commissioners and staff people want to know the latest developments in lighting, windows, and other technologies. To promote energy conservation in utility planning, they must have solid evidence of the performance of these technologies and of effective energy service delivery programs.

The latest work under the LCUP project is suggesting that utilities will foster least-cost planning when it is in their interest to do so. LCUP includes both supply and demand technologies and fosters cost (not necessarily energy) reduction, although frequently the two overlap. 


\title{
NATIONAL ASSOCIATION OF STATE ENERGY OFFICIALS (NASEO)
}

\author{
Name of program: National Association of State Energy Officials (NASEO) \\ Contact person/ \\ organization: \\ Frank Bishop, Executive Director \\ NASEO \\ 122 C Street, NW, Suite 810 \\ Washington, DC 20001
}

(202) 639-8749

(Fax: 202-783-2247)

\begin{abstract}
Audience:
Representatives of 49 state and territorial energy offices. Usually, the member is the person responsible for SECP, EES, ICP, and in some cases the WAP and LIHEAP programs.
\end{abstract}

Funding:

Funding is through state dues and affiliate and associate memberships.

Description:

NASEO's major function is to update the states on events and activities in Washington and to act as a liaison. NASEO is collecting information from the states about the projects for which they have used oil overcharge funds.

NASEO publishes the Quarterly Newsletter and sponsors an annual meeting and a winter meeting in Washington, D.C., each year.

NASEO committees include energy emergencies, integrated energy planning, SECP, government affairs, appliances and building standards, R\&D, electrical siting, and global warming. Committee chairs select members.

Problems:

1. SEOs are not getting sufficient technical information from the national laboratories. The two types of organizations lack sufficient communication, even though a need exists for them to talk with each other. States need and want to know which technologies work, both for energy efficiency and for economic development. SEOs want to do demonstration projects to transfer workable technologies.

2. States are concemed about delivering the OTFA programs and about economic development. The natural overlap between these two activities, along with concerns for environmental protection, has not yet been exploited.

Opportunities: $\quad$ 1. A linkage directly from OBT to NASEO would be effective, as would be a linkage from OBT to OTFA to NASEO. Any linkage from OBT to the national laboratories to NASEO would be less effective, because these players are less well known in the NASEO community. Immediately available opportunities are for speakers at NASEO meetings and articles for the NASEO newsletter. 
2. NASEO looks forward to working more closely with the national laboratories. NASEO is not hearing what the national laboratory projects are, and it would like to know this. NASEO is receiving CADDET newsletters but not necessarily information on what the national laboratories are doing. SEO staffs want "early waming" about technologies under development.

3. States need to deal effectively with buildings they own. The analysts with the SEOs certified to perform technical analyses on commercial buildings are the target audience that needs to know the technologies to recommend. For example, in Mississippi, 22 engineers are certified to conduct technical analyses for ICP. Their firms need to know new products and technologies to improve the efficiency of buildings. The state ICP director supervises the engineer who reviews the technical analysis performed by the private engineers.

4. DOE staff members could speak at NASEO's regional meetings about the new types of energy-efficiency products, tools and practices for schools, hospitals, and congregational buildings, for example. They can't recommend the products, but they can recommend the technologies.

5. S. 247, a bill under consideration to amend the Energy Policy and Conservation Act, establishes an "Engineering Extension Service" to aid small and start-up businesses in discovering useful and practical information relating to manufacturing and commercial production techniques and costs, and other functions. The act states that the service shall provide instruction, referrals, and practical demonstrations in commercializing an entrepreneur's idea or a technology developed by any of the national laboratories or other sources. This is intended to assist the economic development of states. This service, if established, could also be an important teclmology transfer mechanism. 


\title{
THE U.S. CONFERENCE OF MAYORS
}

\author{
Name of program: The U.S. Conference of Mayors \\ Contact person/ \\ organization: \\ J. Thomas Cochran (or Kay Scrimger) \\ Executive Director \\ The United States Conference of Mayors \\ 1620 Eye Street, NW \\ Washington, DC 20006
}

(202) $293-7330$

Audience:

Funding:

Description:
Mayors of cities with populations of 30,000 and more (about 900 cities)

\$3.8 million (estimate)

The U.S. Conference of Mayors is the official organization representing mayors of cities with a population of 30,000 or more. Throughout its 57-year history, the Conference has developed a record of analysis and action on a broad array of urban issues. It has eamed credibility among mayors and their staffs and has access to an extensive network of urban decision makers and leaders, not only in city halls but also in the private sector, foundations, neighborhood organizations, and other parts of cities.

The Conference holds two major meetings each year: the Annual Conference of Mayors (annual meeting) in June, and the winter meeting in January. It publishes a semimonthly newspaper, U.S. Mayor.

The Conference will form a Mayors' Advisory Group on national laboratories and technology transfer. It will select, with FLC guidance, six cities to participate in specific demonstrations of the application of various laboratory technologies. In three additional cities, experiments will be conducted in using "technical volunteers" from local national laboratories to assist in resolving community technical problems.

The Conference is planning to develop an ongoing program to publicize available new technologies to city govemments.

The U.S. Conference of Mayors provides a central mechanism for deliberation and consensus building on urban policy among its cities, for articulation of that policy to the govemment and people of the nation, and for action to assist cities in implementing programs and policies that benefit urban America. Its network consists of more than 900 cities, as well as an affiliate membership organization composed of major corporations, organizations, and others interested in urban development. U.S. Mayor is distributed to more than 5,000 persons in addition to the Mayors' network. Numerous newsletters, legislative bulletins, and other communication vehicles are also used. 
SEPI

Problems:

Opportunities:
None identified.

1. DOE could cosponsor a workshop with the Conference focusing on energy efficiency in city buildings targeted to mayors and building officials.

2. DOE staff members give a presentation at the Conference's Annual Meeting of Mayors. 


\section{NATIONAL ASSOCIATION OF HOME BUILDERS (NAHB)}

Name of program: National Association of Home Builders (NAHB)

Contact person/. organization:

Thomas. A. Farkas

Technology and Codes Deparment

NAHB

15th and $M$ Streets, NW

Washington, DC 20005

(202) $822-0229$

(800) $368-5242$

Audience:

157,000 members, including 50,000 home builders and others in related occupations such as designing buildings and supplying building materials and equipment. NAHB represents most of the major builders in the United States; there are 800 affiliated state and local Home Builder Associations (HBAs).

Funding:

Funded by member dues. NAHB has about 290 full-time staff members; the NAHB National Research Center (see the description of this organization), and the Home Builders Institute (with 50 staff members in Washington and 500 around the nation) are wholly owned subsidiaries.

Description:

NAHB is the trade association for the building industries, performing lobbying functions at the federal, state, and local levels. It is linked with the Home Builders Associations in each state.

The Home Builders Institute (HBI) is a wholly owned subsidiary with a Graduate Builders Institute that offers courses and seminars. Energy is one of 12 educational modules required to graduate from the Institute.

Information flows from NAHB to the $800+$ HBAs at the state and local levels, each of which has its own newsletters, seminars, meetings, and educational programs.

The NAHB has various councils, including the Commercial Buildings Council, the Multifamily Buildings Council, the National Council for the Housing Industry, and the Remodelers Council, each of which has interests in energy efficiency. These councils have their own newsletters, meetings, and publications targeted toward their special interests. Besides the councils, NAHB has an energy committee that follows energy matters, as do a number of state and local HBAs, and a Standing Committee on Research that follows research issues.

NAHB holds three board meetings a year with educational programs at the annual convention in January (held in 1990 in Atlanta). At each board meeting, an education program covers energy technology updates. Speakers are invited to discuss their latest findings, including national laboratory speakers. Board meetings are attended by 2,000 to 2,500 people.

NAHB has a bookstore and a catalog of publications. The organization has credibility and leads as much as follows its members, who look to NAHB to provide them with information. Every aspect of buildings is covered. 
SEPI

Problems:

Opportunities:
1. The barriers to technology adoption should be analyzed in a technologyspecific way and then remedial measures should be taken. General analysis is not adequate to solve the problem.

2. Personnel tumover within OBT and NAHB can interfere with effective ongoing liaisons to enhance technology transfer.

1. Because of its close ties with the NAHB National Research Center, NAHB relies somewhat more on results emerging from the Center than from other sources. These results are transferred somewhat more readily than others. Joint projects between the laboratories and the Center would produce results more rapidly transferred through NAHB.

2. A mechanism is needed to evaluate which energy-efficiency technologies could most effectively go through the NAHB network. Both OBT and NAHB would be represented.

3. NAHB is developing a program involving standards development, builder training and education, certification and quality assurance, research, and promotion and marketing. NAHB would offer the program so that a builder could become registered as an NAKB energy program builder. The houses they built would be certified as built to a standard. A quality assurance program would back up the builder and the house. NAHB would promote and market both the builder and the house as being built to higher energy-efficiency levels. The program's framework would be at the national level, with pilot programs at the state level to enhance implementation.

The key to this program is national and local partnerships with utilities and mortgage lenders, realtors, appraisers, and others. The partnerships would be started at the national level.

The program would yield a group of builders willing to build energyefficient housing and trained in doing so. In the beginning, they would be avant garde builders; however, over time, they would become opinion leaders and could introduce existing and new technologies. They could become an important conduit for energy-efficiency technologies. If the program is to be implemented, it may require a significant investment on the part of the federal govemment. 


\section{NAHB NATIONAL RESEARCH CENTER}

\section{Name of program: National Association of Home Builders (NAHB)} National Research Center

\section{Contact person/ organization:}

Audiences:

Funding:

Description:

\author{
Liza K. Bowles, Vice President \\ NAHB National Research Center \\ 400 Prince Georges Center Boulevard \\ Upper Marlboro, MD 20772-8731
}

(301) $249-4000$

The NAHB itself, and the 157,000 members it represents (including 50,000 builders); client organizations, such as federal agencies; product manufacturens

Funded by clients for research projects; approximately 50 full-time staff members

The Center is a wholly owned not-for-profit subsidiary of the NAHB, with a threefold mission: (1) conduct applied research on buildings technology, (2) promote quality standards in building materials and construction, and (3) help maintain the U.S. building industry's competitive position.

The Center is working on an OBT-funded project with A.D. Little (ADL) and Massachusetts Institute of Technology (MIT) to identify future product and process technologies and develop a methodology to recognize those with the greatest potential value using the NAHB to get them to the marketplace as soon as possible. MIT is working on product technologies and ADL on process technologies, changes in tools and equipment, changes in materials, and the movement from on-site to off-site fabrication of building components and subsystems.

The Center has a Research Home Park about a mile away on 51 acres. One home exists and another is under construction; 25 homes will eventually be constructed there. This facility allows NAHB to test technologies, document results in major trade publications, and display them to 2,500 builders attending the annual spring board meeting in Washington.

The Center's Laboratory Services Division operates a major certification and labeling program for products such as thermal insulation and plastic bathroom fixtures. Products are prominently marked with the Center's label. Nationally recognized tests are performed to ensure that the product meets the specifications issued by the manufacturer.

1. The industry doesn't have an effective way to deal with product failures. Builders and manufacturers obviously want an effective process for dealing with product failure. If recognized processes are not established, standards may become quite stringent to compensate. This would be a strong impediment to invesiment in building industry innovations.

2. The Center has no intemal resources for projects, relying on extramural funding. 
1. The opportunity to use the Research Home Park to display energy-efficiency technologies to the many builder visitors is unique; the Park is a resource that DOE could use in its technology transfer efforts.

2. The National Concrete Masonry Association house being designed now has a strong passive-solar component with storage and will be instrumented for major thermal and indoor air quality testing. This represents an opportunity for potential collaboration.

3. The Research Home Park also represents an opportunity to field test technologies and products that are almost ready for commercialization.

4. Builder focus on technologies is a good way to get feedback for the R\&D and technology transfer programs.

5. The Center writes articles about buildings technologies for a variety of magazines, including Nation's Building News, Professional Builder, Builder, Journal of Light Construction, Energy Digest, Energy Design Update, and Fine Home Building.

6. The Center presents programs at the NAHB annual meeting on advances in buildings technologies.

7. The Center can collaborate in buildings energy-efficiency research with the national laboratories and other organizations. In addition, the Center could help play a broker role to translate research done at the national laboratories into information products and processes useful to buildings industries people. 


\section{NATIONAL INSTITUTE OF BUILDING SCIENCES (NIBS)}

Name of program: National Institute of Building Sciences

Contact person/ organization:

Audience:

Funding:

Description:
David Harris, President

National Institute of Building Sciences

1201 L Street, NW, Suite 400

Washington, DC 20005

(202) 289-7800

Fax: (202) 289-1092

NIBS membership includes representatives from building community trade, professional, and labor organizations; private and public standards, codes, and testing bodies; public regulatory agencies; and consumer groups. NIBS membership, with its three affiliated councils, exceeds 800 .

NIBS has formal ties with many public and private interest groups, including all levels of govemment, consumers, code officials, architects, engineers, builders, developers, product manufacturers, and standards organizations.

NIBS' annual budget ranges from $\$ 3$ to $\$ 4$ million. Funding sources for NIBS' activities include general and restricted support grants from private sources, membership dues, income from sales of services and publications, Congressional appropriations that match NIBS' private income, contracts, and grants from federal and other agencies.

NIBS was established in 1976 as a nongovernmental, nonprofit 501(c)(3). corporation in response to P.L. 93-383. NIBS was conceived as a public/private partnership to serve as an impartial forum to resolve technical and regulatory issues facing the nation's housing and building process.

In accordance with the authorizing legislation, NIBS' four major functions involve

- Developing performance-based criteria, standards, and other technical provisions for evaluating building products, systems, and components.

- Facilitating the use of the performance criteria in evaluation, including certification, listing, and labeling programs.

- Conducting investigations to carry out the first two functions.

- Collecting and disseminating related information.

Current programs include federal design and construction criteria management and dissemination; guidelines for radon, lead-based paint, asbestos, wood protection, and building seismic safety; foreign influences; modular housing: building thermal envelopes research; and fire hazards. 
Problems:

Opportunities:
1. NIBS depends on outside funding and has limited resources to develop or transfer information without outside funding.

2. Environmental issues, such as indoor air quality, are developing rapidly and are placing new demands upon the building community.

3. The building community is composed of so many different sectors that the federal govemment has difficulty interfacing directly with each of the organizations representing the diverse sectors.

4. Better coordination and communication are needed to continue to improve standards, codes, regulations, and practices governing technology evaluation, development, and application.

1. NIBS can assist in analyzing barriers to and suggesting solutions for the promulgation of information to the buildings community. Issue papers developed on these problems go to the councils for review, which strengthens such papers.

2. NIBS can reach a broader cross section of the building community than other organizations can

3. NIBS has developed, maintains; and distributes the "Construction Criteria Base" (CCB), a 250,000 page compilation of technical building information on an automated CD-ROM based system. CCB includes building specifications, standards, codes, and other technical criteria. Automated design tools (applications software and technical information) and other software are included. Nine hundred current subscribers, growing at the rate of 30 to 40 subscribers a month, are paying $\$ 1,000 /$ year for CCB information. The CCB can be used as a vehicle to transfer information and applications software programs to subscribers, predominantly design professionals.

4. NIBS can develop criteria on how specific technologies are to be installed and how they should perform and can relate theirs use to the construction "chain"-odesigners, specification writers, contractors, facility managers, developers, and building owners. Developing criteria is an essential yet expensive step. Once the criteria are developed, the information can be distributed through the $\mathrm{CCB}$, an efficient dissemination medium.

5. NIBS can help in supporting and coordinating national and international product testing and certification activities affecting the U.S. building process.

6. NIBS can serve as a forum to facilitate cooperative programs among govemment agencies and the private sector, both domestically and internationally. 


\section{BULDING THERMAL ENVELOPE COORDINATING COUNCIL (BTECC)}

Name of Program: Building Thermal Envelope Coordinating Council (BTECC)

Contact:

Audience:

Funding:

Description:

Problems:

Opportunities:

\author{
Bruce Vogelsinger \\ National Institute of \\ Building Sciences \\ 1201 L Street, N.W. \\ Washington, DC 20005
}

(202) 289-7800

Fax: (202) 289-1092
Erv Bales

New Jersey Institute of Technology

School of Architecture

323 High Street

Newark, NJ 07102

(201) 596-3010

Members of building community sectors with an interest in building envelope research, design, and operation. Includes product manufacturers, design professionals, researchers, academia, codes and standards, government agency, labor, and construction representatives.

Sources of funds for BTECC activities include general support grants, dues, and contracts from public and private organizations. BCS had funded some BTECC activities since FY 1985.

BTECC was established as an independent council under the auspices of the National Institute of Building Sciences to coordinate industry and govemment R\&D efforts in building thermal envelope materials and technologies. Developing periodic national plans for the building envelope industry is a principal activity. BTECC focuses on research and technical activities related to

- Developing new knowledge of improved building energy-efficient materials, components, and systems;

- Modeling thermal envelope systems and subsystems;

- Stimulating use of new and existing technology and technology verification projects; and

- Coordinating thermal envelope and service system interfaces.

The solar industry and others have information on such topics as heat and mass transfer and daylighting that architects and engineers may not have. The research and applications communities sometimes have difficulty obtaining the information they need.

A tie has already been established between OBT and BTECC. With a small amount of support ${ }_{0}$ BTECC could accomplish a great deal of technology transfer for OBT. BTECC has established research-coordinating committees composed of industry, govemment, and university representatives. These committees offer a substantial opportunity for leveraging. BTECC runs periodic workshops, primarily with DOE funds, meets several times a year, and tackles specific projects on an as-needed basis. 


\section{SEN}

\section{APPENDIX D}

Framework Used to Identifying

Organizational Linkages 
Table D-1. Existing and Proposed Technology Transfer Activities

Matrix classified by

1. Technology Transfer Functions

- Research Results

- New and Existing Tools, Technologies and Practices

- New and Existing non-OBT Tools, Technologies and Practices

- Program Awareness

2. Target Audiences

Building researchers (nationwide)

Federal

Buildings

Conservation programs

Legislative concems

State and local

Buildings

Conservation programs

Legislative concems

Private sector

Product manufacturers and distributors

Energy intermediaries

Conservation programs

Consumers/end users

Internal DOE (OBT and up)

and laboratories 
Table D-2. Organizational Leverage Points for OBT Linkages (Actual and Potential)

Technology Transfer Functions

\begin{tabular}{|c|c|c|c|c|}
\hline $\begin{array}{l}\text { Target } \\
\text { Audiences } \\
\end{array}$ & $\begin{array}{l}\text { Research } \\
\text { Results } \\
\end{array}$ & $\begin{array}{l}\text { New OBT Tools, } \\
\text { Technologies, } \\
\text { and Practices } \\
\end{array}$ & $\begin{array}{l}\text { Existing OBT and non-OBT } \\
\text { Tools, Technologies, } \\
\text { and Practices } \\
\end{array}$ & $\begin{array}{l}\text { Program } \\
\text { Awareness } \\
\end{array}$ \\
\hline $\begin{array}{l}\text { Buildings } \\
\text { Researchers }\end{array}$ & $\begin{array}{l}\text { Office of Science and } \\
\text { Technology (OSTI) } \\
\text { National Technical } \\
\text { Information Service } \\
\text { (NTIS) } \\
\text { Solar Technical } \\
\text { Information Program } \\
\text { (STIP) } \\
\text { Professional } \\
\text { societies } \\
\text { Oak Ridge National } \\
\text { Laboratory (ORNL) } \\
\text { (TT publications) } \\
\text { (Technology Briefs, } \\
\text { Research in Progress, } \\
\text { Buildings Energy } \\
\text { Technology, Recent } \\
\text { Publications) }\end{array}$ & N/A & 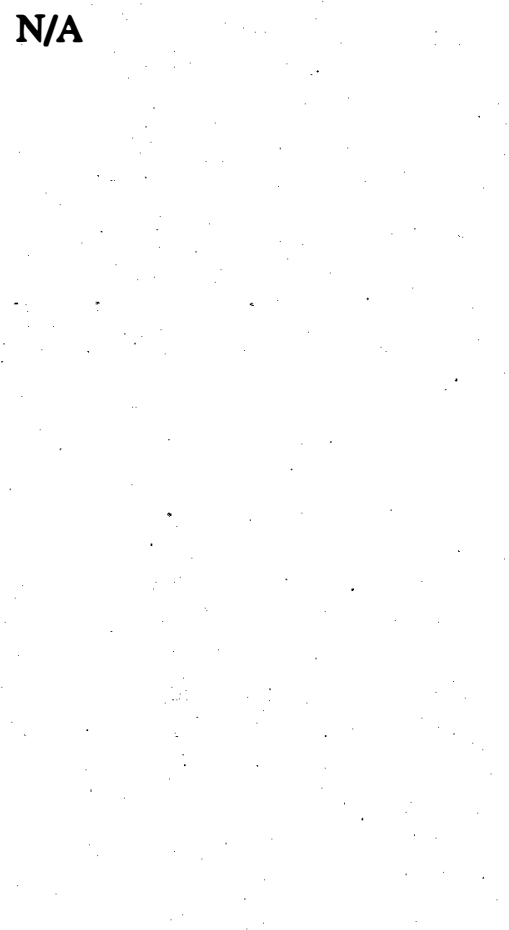 & $\begin{array}{l}\text { ORNL Program Overview } \\
\text { DOE Office of Public } \\
\text { Affairs }\end{array}$ \\
\hline
\end{tabular}


Table D-2. Organizational Leverage Points (continued)

Technology Transfer Functions

\begin{tabular}{|c|c|c|c|c|}
\hline $\begin{array}{l}\text { Target } \\
\text { Audiences } \\
\end{array}$ & $\begin{array}{l}\text { Research } \\
\text { Results } \\
\end{array}$ & $\begin{array}{l}\text { New OBT Tools, } \\
\text { Technologies, } \\
\text { and Practices } \\
\end{array}$ & $\begin{array}{l}\text { Existing } \mathrm{OBT} \text { and non-OBT } \\
\text { Tools, Technologies, } \\
\text { and Practices } \\
\end{array}$ & $\begin{array}{l}\text { Program } \\
\text { Awareness }\end{array}$ \\
\hline \multirow[t]{4}{*}{$\begin{array}{l}\text { Federal } \\
\text { Buildings }\end{array}$} & $\begin{array}{l}\text { National Institute } \\
\text { of Standards and } \\
\text { Technology (NIST) }\end{array}$ & $\begin{array}{l}\text { National Energy } \\
\text { Service Council } \\
\text { (NESC) }\end{array}$ & $\begin{array}{l}\text { NESC } \\
\text { Trade associations }\end{array}$ & $\begin{array}{l}\text { *DOE Office of } \\
\text { Public Affairs }\end{array}$ \\
\hline & $\begin{array}{l}\text { Federal Emergency } \\
\text { Management Program } \\
\text { (FEMP) }\end{array}$ & $\begin{array}{l}\text { Trade associations } \\
\text { GSA }\end{array}$ & $\begin{array}{l}\text { ?GSA } \\
\text { ?DOD }\end{array}$ & \\
\hline & $\begin{array}{l}\text { ?Construction Engi- } \\
\text { neering Research } \\
\text { Laboratory (CERL)** }\end{array}$ & $\begin{array}{l}\text { DOD } \\
\text { FEMP }\end{array}$ & $\begin{array}{l}\text { FEMP } \\
\text { TCERL }\end{array}$ & \\
\hline & $\begin{array}{l}\text { 2General Services } \\
\text { Administration (GSA) } \\
\text { Department of Defense } \\
\text { (DOD)-Energy }\end{array}$ & $\begin{array}{l}\text { PCERL } \\
\text { NIST }\end{array}$ & NIST & \\
\hline
\end{tabular}

\footnotetext{
* Denotes potential.

**CERL not defined; who knows what this is?

$?$ Denotes a possibility to be explored.
} 
Table D-2. Organizational Leverage Points (continued)

Technology Transfer Functions

\begin{tabular}{|c|c|c|c|c|}
\hline $\begin{array}{l}\text { Target } \\
\text { Audiences }\end{array}$ & $\begin{array}{l}\text { Research } \\
\text { Results } \\
\end{array}$ & $\begin{array}{l}\text { New OBT Tools, } \\
\text { Technologies, } \\
\text { and Practices } \\
\end{array}$ & $\begin{array}{l}\text { Existing OBT and non-OBT } \\
\text { Tools, Technologies, } \\
\text { and Practices }\end{array}$ & $\begin{array}{l}\text { Program } \\
\text { Awareness }\end{array}$ \\
\hline $\begin{array}{l}\text { Federal } \\
\text { Conservation } \\
\text { Programs }\end{array}$ & $\begin{array}{l}\text { *Residential and } \\
\text { Commercial Conser- } \\
\text { vation Programs } \\
\text { (RCCP)-->former } \\
\text { OSLAP grant pro- } \\
\text { grams (Weather- } \\
\text { ization Assitance } \\
\text { Program [WAP], } \\
\text { State Energy } \\
\text { Conservation } \\
\text { Program [SECP], } \\
\text { Insioutional Conser- } \\
\text { vation Program [ICP]) }\end{array}$ & $\begin{array}{l}\text { OSLAP (OTFA) } \\
\text { NESC } \\
\text { Computer Software } \\
\text { Management and } \\
\text { Information Center } \\
\text { (COSMIC) } \\
\text { NARUC->PUCs } \\
\text { ?Utilities }\end{array}$ & $\begin{array}{l}\text { RCCP->OSLAP (OTFA) } \\
\text { NESC } \\
\text { COSMIC } \\
\text { NARUC }->\text { PUCs } \\
\text { ?Utilities }\end{array}$ & $\begin{array}{l}\text { RCCP-->OSLAP } \\
\text { (OTFA) }\end{array}$ \\
\hline
\end{tabular}

* Denotes potential.

? Denotes a possibility to be explored. 
Table D-2. Organizational Leverage Points (continued)

Technology Transfer Functions

\section{Target \\ Audiences}

Research

Results

Federal

Legislative

Concerns

*Congressional

Research Service

(CRS)

and Practices

\section{New OBT Tools, \\ Existing OBT and non-OBT}

Technologies,

N/A

Tools, Technologies,

and Practices

\section{N/A}

Program

Awareness

Public information groups (PIGs)

Chief executive officers

Trade associations

DOE Office of Legislative Affairs

* Denotes potential. 
Table D-2. Organizational Leverage Points (continued)

Technology Transfer Functions

New OBT Tools, Existing OBT and non-OBT

Audiences

Research

Results

State and Local

Buildings

Housing and Urban

Development (HUD)

$\rightarrow$ Public Housing

Authorities (PHAs)

HUD Assisted Housing

Programs

Technologies,

and Practices

\section{Tools, Technologies,}

and Practices

HUD-->PHAs

RCCP-->ICP

HUD-->PHAs

RCCP-->ICP
Program

Awareness

RCCP-->Conservation States

Conference (ASC)

NASEO

NARUC

HUD Rehabilitation

Programs

RCCP $\rightarrow$ Institutional Conservation Program (ICP) 
Table D-2. Organizational Leverage Points (continued)

Technology Transfer Functions

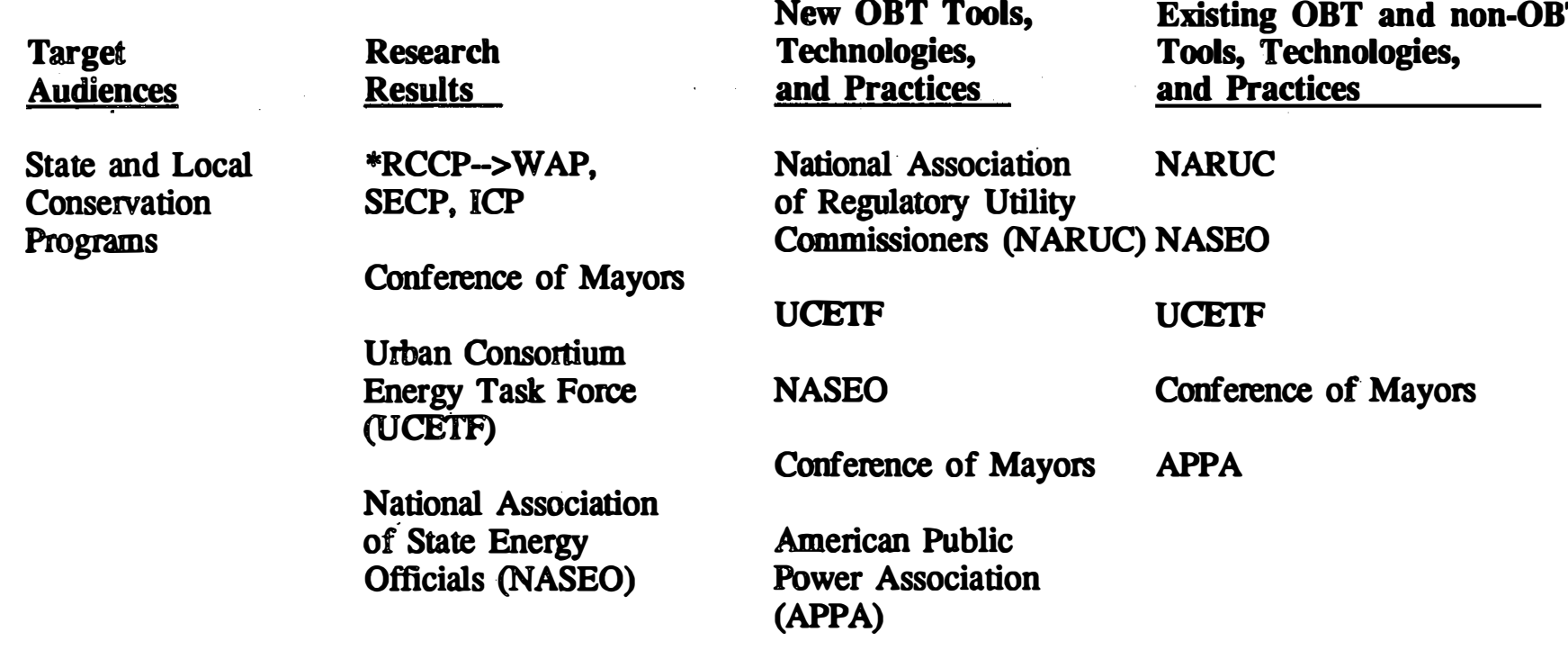

Program

Awareness

Public interest

groups

Trade associations

RCCP->Conservation

Conference (ASC)

NASEO

* Denotes potential. 
Table D-2. Organizational Leverage Points (continued)

Technology Transfer Functions

\begin{tabular}{lll} 
New OBT Tools, & $\begin{array}{l}\text { Existing OBT and non-OBT } \\
\text { Tools, Technologies, }\end{array}$ & $\begin{array}{l}\text { Program } \\
\text { Technologies, }\end{array}$ \\
and Practices & and Practices & Awareness \\
\hline
\end{tabular}

Target Research

Audiencés

Results

State and Local

Legislative

Concems
Code officials

(either program or legislature)

Code officials

(either program or

legislature)

National Conference

of States and Building

Codes and Standards

(NCSBCS)
NCSBCS

NASEO
National Civil Engineering Laboratory (NCEL)

Conference of Mayors

Nat'l. Governors Conference 
Table D-2. Organizational Leverage Points (continued)

Technology Transfer Functions

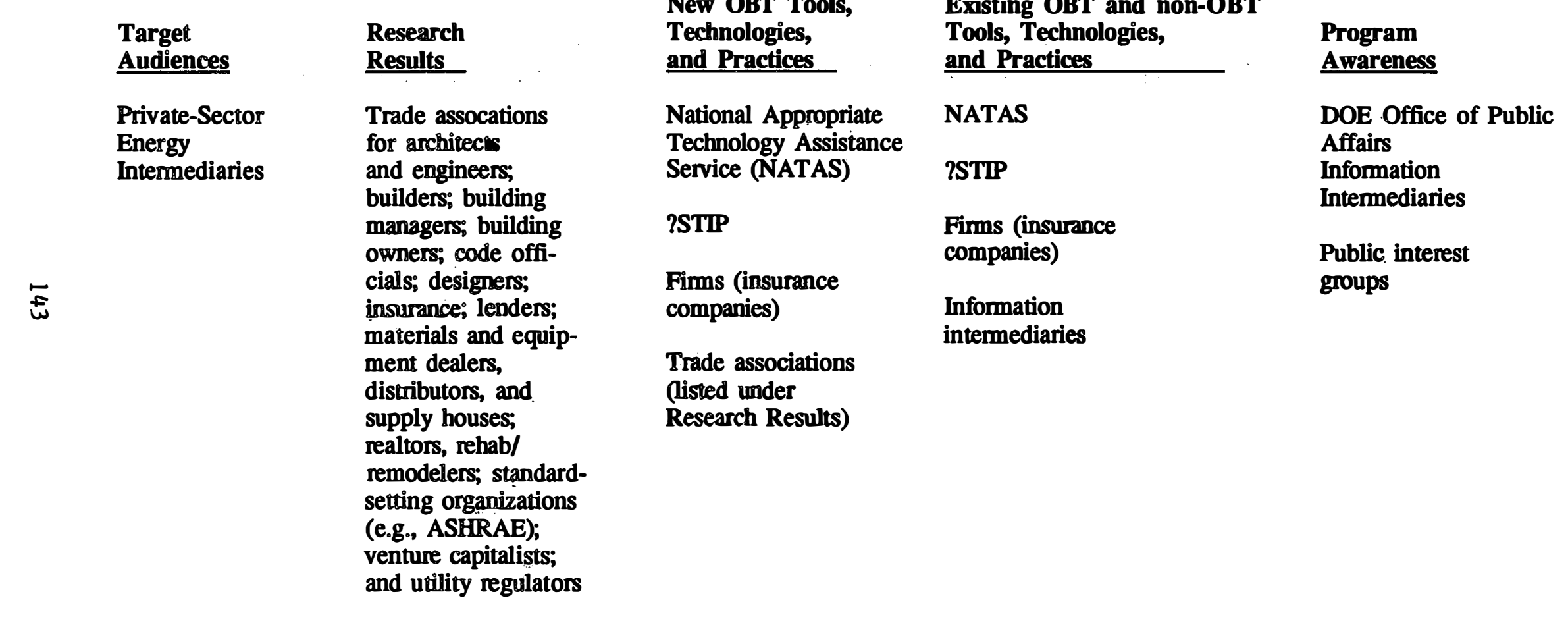

? Denotes a possibility to be explored. 
Table D-2. Organizational Leverage Points (continued)

Technology Transfer Functions

New OBT Tools, $\quad$ Existing OBT and non-OBT

\section{Target}

Audiences

\section{Product}

Manufacturers

and Distributors

\section{Research}

Results

Industry associations

*Federal Laboratory

Consortium

*NIST Office of

Research and Tech-

nology Applications

(ORTA)

*NIST: Center for

Building Technology

(CBT)

\section{Technologies,}

and Practices

Trade associations

(listed earlier)

*NIST-->Small

Business Development

states
Councils (SBDCs) in

\section{Tools, Technologies, Program}

and Practices

Trade associations

(listed earlier)

*NIST-->SBDCs

Information

intermediaries
Awareness

\section{*NIST-->SBDCs}

Trade associations

(listed earlier)

* Denotes potential. 
Table D-2. Organizational Leverage Points (continued)

Technology Transfer Functions

\section{New OBT Tools, Existing OBT and non-OBT}

Technologies,

and Practices

CAREIRS

NATAS
Existing OBT and non-OBT
Tools, Technologies,

and Practices

\section{CAREIRS}

NATAS

Information

intermediaries
Consumers/

\section{CAREIRS}

Program

Awareness

Information

intermediaries

*Cable TV (Tumer

Broadcasting)

DOE Office of Public Affairs

\section{CAREIRS}

NASEO

NARUC

Advertising agencies

* Denotes potential. 
Table D-2. Organizational Leverage Points (continued)

Technology Transfer Functions

\begin{tabular}{|c|c|c|c|c|}
\hline $\begin{array}{l}\text { Target } \\
\text { Audiences }\end{array}$ & $\begin{array}{l}\text { Research } \\
\text { Results } \\
\end{array}$ & $\begin{array}{l}\text { New OBT Tools, } \\
\text { Technologies, } \\
\text { and Practices } \\
\end{array}$ & $\begin{array}{l}\text { Existing OBT and non-OBT } \\
\text { Tools, Technologies, } \\
\text { and Practices } \\
\end{array}$ & $\begin{array}{l}\text { Program } \\
\text { Awareness }\end{array}$ \\
\hline \multirow[t]{4}{*}{$\begin{array}{l}\text { Private-Sector } \\
\text { Conservation } \\
\text { Programs }\end{array}$} & $\begin{array}{l}\text { Electric Power } \\
\text { Research Institute } \\
\text { (EPRI) }\end{array}$ & GRI & $\begin{array}{l}\text { EPRI } \\
\text { GRI }\end{array}$ & $\begin{array}{l}\text { *OBT (newsletter) } \\
\text { EPRI publications }\end{array}$ \\
\hline & $\begin{array}{l}\text { Gas Research } \\
\text { Institute (GRI) }\end{array}$ & $\begin{array}{l}\text { National Association } \\
\text { of Energy Service Com- } \\
\text { panies (NAESCO) }\end{array}$ & $\begin{array}{l}\text { NAESCO } \\
\text { AGA }\end{array}$ & $\begin{array}{l}\text { GRI publications } \\
\text { EEI publications }\end{array}$ \\
\hline & & $\begin{array}{l}\text { American Gas Asso- } \\
\text { ciation (AGA) }\end{array}$ & & AGA publications \\
\hline & & $\begin{array}{l}\text { Edison Electric } \\
\text { Institute (EEI) }\end{array}$ & & NAESCO publications \\
\hline
\end{tabular}

\footnotetext{
* Denotes potential.
} 
Table D-2. Organizational Leverage Points (concluded)

Technology Transfer Functions

\begin{tabular}{|c|c|c|c|c|}
\hline $\begin{array}{l}\text { Target } \\
\text { Audiences } \\
\end{array}$ & $\begin{array}{l}\text { Research } \\
\text { Results } \\
\end{array}$ & $\begin{array}{l}\text { New OBT Tools, } \\
\text { Technologies, } \\
\text { and Practices } \\
\end{array}$ & $\begin{array}{l}\text { Existing OBT and non-OBT } \\
\text { Tools, Technologies, } \\
\text { and Practices } \\
\end{array}$ & $\begin{array}{l}\text { Program } \\
\text { Awareness } \\
\end{array}$ \\
\hline $\begin{array}{l}\text { Internal DOE } \\
\text { (OBT \& up) }\end{array}$ & $\begin{array}{l}\text { ORNL (TT } \\
\text { publications) } \\
\text { *OBT (newsletter) }\end{array}$ & $\begin{array}{l}\text { OBT program manager } \\
\text { weekly activity } \\
\text { report } \\
\text { Executive Committee } \\
\text { (EXCOM) } \\
\text { Office of the Director } \\
\text { (OD) meetings } \\
\text { *OBT (newsletter) } \\
\text { National laboratory } \\
\text { (publications) }\end{array}$ & $\begin{array}{l}\text { OBT program manager } \\
\text { weekly activity } \\
\text { report } \\
\text { EXCOM } \\
\text { OD meetings } \\
\text { *OBT (newsletter) }\end{array}$ & $\begin{array}{l}\text { Multiyear Plan (MYP) } \\
\text { ORNL (TT publications) }\end{array}$ \\
\hline
\end{tabular}

* Denotes potential. 
APPENDIX E

Examples of Technology Transfer Activities and Their Rankings 
1. Information Products

$\underline{\text { Rank }}$

Publications

0 A Energy and Engineering Bibliography - for mechanical engineering faculty. Developed by ACEC. Spinoff from the Institute on Energy and Engineering Education. Published two times, most recently in FY 1989. Annual: $\$ 15,000$. Cumulative: $\$ 30,000$ (2 times). (Existing)

29 B. Recent Publications of DOE's Office of Buildings and Community Systems - for building researchers and OBT program managers. ORNL-produced bibliography, not annotated. Lists OBT products; one-time publication covering 1985-1988 publications. Completed in FY 1989. $\$ 100,000$. If Database Inquiry Service were in place it would cost $\$ 5,000$ (for printing) $\$ 20,000$. (Proposed again)

(2), 18, 2.6

0 C. Research Update - Existing Buildings Efficiency Research (EBER) - for national laboratory researchers and consultants. Presents the status of the EBER program in 1987-1988, done by ORNL. Not funded by BCD Analysis and Technology Transfer program; funded by OBT EBER program. (Existing)

24 D. Buildings Energy Technology - for building researchers. Annotated bibliography. Started January 1988, published monthly by OSTI. Annual: $\$ 35,000$. Cumulative: $\$ 70,000$ (2 years). (Existing)

(3), $21,3.0$

25 E. Research in Progress - for DAS/C and building researchers; OSLAP staff. OSTI-produced annotated project list. Started FY 1986, published every other year. One is planned for FY .1990. Annual: \$17,500. Cumulative: \$75,000. (Existing)

(3), 20, 2.9

27 F. Technology Briefs (Program Overviews) - for OBT program managers, buildings researchers, state energy offices, and others. SERI-published two-page (on one sheet) documents describing elements of OBT R\&D program, such as IAQ, roofing research, and lighting research. Also published in Buildings Energy Technology, No. 9. FY 1988: $\$ 44,000$ for 12 briefs; FY 1989: $\$ 60,000$. (Existing) $\$ 20,000$ proposed cost.

(4), 19, 2.7

28. G. Program Overviews - for DAS/C. SERI-produced booklets describing in general terms the organization of energy conservation research offices at. DOE and briefly describing R\&D programs. (Energy. Conversion and Utilization, Buildings and Community Systems, OTS, and OIP, too.) $\$ 15,000$. (Existing)

*Code for numbers: (number of team members selecting the item as one of the 20 most preferred items), raw score, raw score divided by the seven team members who were ranking the activities. For example,

(2) = number of team members selecting the item,

18 = raw score derived by adding the total number of points assigned

(rank \#1 = 20 points), and

2.6 = raw score (18) divided by 7 . 


\section{Information Products (continued)}

\section{Rank}

39 H. Energy Conservation Technical Information Guide, Volume 4, Commercial Buildings - for anyone interested in energy conservation. SERI-prepared directory to sources of information about energy conservation such as research centers, associations, directories, software, publications. Published in FY 1988. Cumulative: $\$ 150,000$ (WAPA $\$ 60,000$; OBT \$90,000) (one time). (Proposed)

(1), $11,1.6$

4 K. Trade magazine news releases and articles - for trade press. ORNL subcontracted to Sumner-Rider. News releases are sent to various trade organizations and newspapers; if they pursue it, they are helped with articles to publish. Annual: $\$ 45,000$. Cumulative: $\$ 135,000$ (3 years). (Existing)

(7), 82, 11.7

41 L. List of building trade publications - for OBT division directors only. ORNL subcontracted to Editors Ink of Washington. List includes editor and contact information, and brief description of readership and editorial scope. Completed in FY 1987. Will redo. $\$ 5,000$.

(2), 8, 1.1

40 N. "In-progress report" - for private-sector firms on both OBT and non-OBT tools, technologies, and practices. Too often, technology transfer is viewed as the last step of a linear process; exploratory research, basic research, and applied research and development, followed by technology transfer. This approach is slow, inefficient, and not reflective of the iterative nature of the technology-development-to-utilization process.

A way to speed up the process is to involve private-sector firms as early as possible. The development of an "in-progress" report that describes new OBT initiatives, ongoing work, research or technology transfer accomplishment and even planning activities may help to achieve early interest and collaboration by industry.

By letting target audience(s) in on OBT activities very early on, it may be possible for them to (1) integrate these activities into their own plans; (2) have an impact the direction of the work to be of more relevance to them or their industry; and/or (3) monitor OBT activities for areas of interest that fit their needs and timing. Including technology transfer accomplishments will also give them valuable competitive information, thus heightening interest in such a publication.

The difficult part of this proposition would be designing of the target audience and developing the distribution lists. Such a report would nead the appropriate individuals involved if it is to have its desired impact. Data exist at DOE and the labs on past collaborators to start this process (PNL has some appropriate data). It may also be useful to work with the SBIR program to look for logical (technical) ties between proposals and OBT activity, however distant they may be. $\$ 50,000$. (Proposed)

(2), 9, 1.3 
1. Information Products (continued)

Rank

0 O. Publication support to and from SEOs - for SEOs and other information service organizations such as CARIERS, NATAS, and STIP. Gather state samples of brochures, factsheets, and other information products, and use as examples of what to use and produce. Provide a mailing of OBT and CAREIRS factsheets to SEOs. Provide cameraready text and graphics to states. $\$ 20,000$. (Proposed)

37 P. A Compendium of Energy Conservation Success Stories - published for DAS/C. Not funded by OBT technology transfer program; funded by DAS/C. $\$ 25,000$. (An update is proposed.)

(2), $12,1.7$

\section{Software}

33 Q. ASEAM-2.1 Technology Transfer. ASEAM-2 was developed for practitioners, ESCOs, utilities, SEOs. ACEC and NESC are disseminating this software package measuring building energy performance, costbenefit, and payback periods on altemative retrofit measures. Completed in FY 1988. Cumulative: $\$ 170,000$ (5 years).

The American Consulting Engineers Council (ACEC) has proposed several activities to promote the use of ASEAM: (1) a hotline for the 300 ASEAM users (\$13K) and (2) four quarterly newsletters (\$43K). Jim Firovid is developing a 3-year plan for additional ASEAM features. Total: $\$ 60,000$. (Proposed)

(1), $15,2.1$

S. SOLAR-5 (A Micro-Computer Energy Conserving Design Tool). Murray Milne of UCLA developed both a mainframe and a PC version of SOLAR-5, with cost sharing from the OBT technology transfer program. The software package is used by over half the schools of architecture in North America. Because of the "freeware" concept, Murray estimates that the population of usens more than doubles every year and currently reaches well into the thousands. Murray has proposed to update SOLAR-5 by adding an array. of new energy conservation features that will keep it current and appealing in the eyes of prospective new users. The capabilities that will be added to SOLAR-5.2 include internal mass, monthly/yearly weather data, BEPS report, screen color, graphics, floppy disk portability, hard disk installation, math coprocessor, data input enhancements, and an updated users manual. $\$ 39,000$ (Proposed)

32 T. Energy Scheming-1.0. Charlie Brown (no relation to Marilyn!) has proposed to test and furcher develop an energy scheming package--a software package that helps incorporate energy and environment factors into the schematic design process. It would be a design tool for practicing architects and educators. (\$102,000) (Proposed) (Has had no DOE support to date.)

(1), 16, 2.3

20 U. Electronic mail network for OBT and its national laboratories. Frequently laboratory personnel interact with headquarters and with each other on a variety of projects. Interlab projects require close coordination and communication. Labs tend also to have few support staff to assist in communications. This project would explore the technical potential and cost of linking headquarters and laboratory personnel electronically. $\$ 15,000$. (Proposed)

(3), 25, 3.6 


\section{Information Products (continued)}

Rank

13/14 V. Computer-based information systems for technology transfer. DOE is a major producer of new buildings research data but is often criticized for inadequate technology transfer. This is not due to the lack of interest, but rather to the cost and effectiveness of various dissemination media. New information technology, such as multimedia, can do a better job at lower cost. The first generation of these new information systems is now commercially available and becoming more widely used. This is an opportunity for DOE to take a lead role in demonstraning to the building community more efficient and innovative approaches for technology transfer to the architectural, engineering, and construction industries. At this time, none of the existing OBT technology transfer efforts use these emerging media approaches already being used by other federal agencies (NIST, NIBS) and by major U.S. corporations. It would be valuable to compare the success of these new approaches with that of similar efforts using more traditional print media.

Prototype multimedia information kiosks should be developed, tested and evaluated with appropriate building industry user groups in corporate lobbies, industry trade shows, and professional workshops. This is an opportunity for DOE to take a lead role in demonstrating to the building community more efficient and innovative approaches to technology transfer. $\$ 100,000$ (Proposed)

(3), 37, 5.3

\section{Data Bases}

5 W. Building Efficiency and Conservation Network (BEACON) - for building practitioners and the general public. It is based on the assumption that providing credible, accessible performance information on building energy technologies will spur their adoption. Basic information on OBT and non-OBT technologies and practices would be normalized, and tailored responses would be presented in a manner that allows interested persons to easily compare performance in different climate zones and for different building types.

DOE would cooperate with NIST, industry associations, and other concemed organizations and utilities. The center would assemble data from several existing data bases (including LCUP and BECA and data bases maintained by states and power authorities), and assess, standardize, and simplify the data. A computerized network would possibly be centered at NIST with satellites at other locations.

BEACON is a major new initiative requining five FTE professional staff to establish and operate. $\$ 400,000$ for the first year. (Proposed) (Cumulative funding over 5 years is proposed at $\$ 5.6$ million.)

(5), 74, 10.6

44 Z. International Residential Energy Use Data Base - for policymakers, forecasters, and analysts. LBL has compiled a database for 11 Organization for Economic Cooperation and Development (OECD) countries (Canada, Denmark, France, Germany, Holland, Italy, $J_{a p a n}$ Norway, Sweden, the United Kingdom, and the United States) on population, dwelling stock by type, economic indicarors, delivered energy consumption by fuel type, and climate data. It allows energy-use trends to be analyzed cross-nationally. Cumulative funding unknown; FY 1989 Funding: \$130,000. (Existing)

(2), 7,1 


\section{Information Products (concluded)}

$\underline{\text { Rank }}$

22/23 AA. Database inquiry service - for buildings reseanchers. This would be a computerized energy technology documents data base. It would be based on an annotated bibliographic database of technology, with national laboratories responsible for maintaining their segments. A lead lab would refer inquiries to other labs. \$50,000. (Proposed) (2), 24, 3.4

\section{Exhibits/Displays}

8 BB. Modular display of OBT research accomplishments - for building practitioners. This task involves the design and construction of a display focusing on the OBT R\&D program to be used at rade shows. This display would highlight OBT accomplishments of interest to building practitioners, including builders, HVAC contractors, and building material suppliers. For instance, the annual convention and exposition held by the National Association of Home Builders aftracts 50,000-60,000 registrants each year.

It would be modular so that the content could be altered to meet the needs and interests of different practitioner audiences. Existing displays would be inventoried to determine their applicability, and guidelines for future displays would be developed to ensure the compatibility with the modular OBT display. A schedule of potential exhibitions could be developed for maximum cost-effective exposure of the exhibit to the buildings industries. \$75,000. (Proposed)
(6), 62, 8.9

17 CC. Information kiosk on the OBT program - for exhibition at trade associations and other shows and expositions. This could be a product of research in computer-based information systems for technology transfer (\# V above). A kiosk could be included in a display (\# $\mathrm{BB}$ above) and could be designed to get feedback on user interests. $\$ 30,000-\$ 50,000$. (Proposed).

(2), 28, 4

\section{Curricula}

42/43 DD. Building energy case study curriculum materials - for architecture faculty. Published by Association of Collegiate Schools of Architecture. Contains three case studies. Currently under review. Second phase will begin in FY 1990. Annual: \$42,000. Cumulative: \$84,000 (2 years). (Existing)

(1), 8, 1.1

18 EE. Curriculum materials for technical schools - for building designers. This task will assess the curriculum materials currently used by 2-year technical schools to train practitioners in the buildings industries. A program will be initiated to develop supplemental curriculum materials to improve the effectiveness of practitioner training. $\$ 125,000$. (Proposed)

(3), 26, 3.7 
2. OBT Management Support of Technology Transfer

OBT will undertake management activities to support and enhance the effectiveness of technology transfer efforts, such as approval of technology transfer components of project plans and assignment of specific technology transfer responsibilities to OBT program managers.

$\underline{\text { Rank }}$

2 A. OBT technology transfer roundtable - for OBT technology transfer planning. A roundtable will be conducted to assess the technology transfer needs of the buildings and community systems industries. It will be modeled after the OBT Technology Transfer Roundtable that was successfully held in 1984 . This roundtable would bring together researchers, technology transfer specialists, and users to discuss R\&D and technology transfer agendas and to form a network. Users could include a few researchers in the building industries trade asssociations (e.g., BOMA, AIA, etc.), federal agency people (e.g., HUD, Energy Information Administration), lab people, and perhaps CEOs.

In addition to assessing needs and reviewing DOE technology transfer plans, the roundtable could include information on technology acquisitions, new information products, and new developments that could lead to products and processes for their companies.

Selected members of the roundtable could become members of the Technical Review Panel (TRP) for Technology Transfer. $\$ 15,000$. (In process)

(6), 105, 15

6 B. Technical Review Panel - for OBT program management. OBT management will establish a Technical Review Panel (TRP) for Technology Transfer. A standing committee of 8-12 members, the TRP will advise the OBT A\&TT Program Manager. It will meet at least annually (possibly semiannually) to review the technology transfer program and recommend activities to the Program Manager. The TRP will comprise DOE laboratory staff and private/public sector representatives. The advisory group should include industry representatives from companies such as Andersen Windows, General Electric, and OwensComing so that their technology transfer know-how can be transferred to OBT and laboratory staff. National laboratory staff will support program management with the panel. Staff and support: $\$ 10,000$. (Proposed)

(4), 69, 9.9

1 C. Technology transfer handbook. Develop a technology transfer handbook for OBT Program Managers, or perhaps for all of the conservation programs, if cost-sharing is obtained, and the broader coverage seems appropriate. The handbook will discuss (1) the importance of technology transfer, (2) technology transfer planning, (3) procedures and responsibilities, (4) technology transfer resources, and (5) monitoring and evaluating technology transfer activities. $\$ 30,000$ from OBT and $\$ 30,000$ from CE; $\$ 50,000$ from OBT alone. (In process)

(7), 107, 15.3 


\section{OBT Management Support of Technology Transfer (continued)}

\section{Rank}

12 E. Provide technical assistance and require a technology transfer plan as part of all R\&D projects - for OBT program managers, researchers, and all users. The technology transfer component of task and project plans would be reviewed by technology transfer specialists. A management decision would be needed that the technology transfer component would actually affect project funding decisions. Technology transfer can be most appropriately and effectively conducted within the context of the research programs. OBT research programs should be structured to include a specific technology transfer task, with an approved technology transfer plan, and funded so that goals can be achieved without sacrificing efforts for R\&D. Of course, an appropriate task manager must be selected to conduct and represent this activity in addition to the annual review of technology transfer activities.

Active annual reviews of program-wide and division level technology transfer activities would be held at OBT's annual laboratory reviews. These would be substantive reviews of progress against established milestones and agread-upon accomplishments for technology transfer tasks, specifically. The review of progress in technology transfer would be funded through programs (where appropriate) and through the program-wide A\&TT budget where appropriate (\$3K per program, project, or task reviewed).

Within this context, the role of the office-level technology transfer programs becomes (1) approval, oversight, and review of programmatic technology transfer activities; and (2) development of more generic technology transfer knowledge and tools for all programmatic efforts. This approach would help to provide active, relevant, and consistent assistance to technology transfer activities. A second role for the office-level activities could be as a consultant to the programs on an as-needed basis for program-specific needs. Staff and support: $\$ 10,000$. (Proposed)

(5), 42, 6

16 F. OBT Technology Transfer Award - for headquarters and national laboratory staff; perhaps include one or more monetary awards at a significant level (e.g., $\$ 5 \mathrm{~K}$ to $\$ 10 \mathrm{~K}$ ). Staff and award dollars: $\$ 10,000$ (Proposed)

(2), 30, 4.3

30 H. Demonstration project funded by all three divisions - federal buildings. Each one could do its own demonstration as part of it. This could be done with FEMP involvement. Staff and support: \$10,000. (Proposed)

(1), 18, 2.6

36 J. Public relations work at DOE and the Labs - for general program awareness purposes; to improve dissemination of information about successful projects and programs. Staff and support: \$8,000. (Proposed)

(1), 13, 1.9

11 L. Technology Transfer in Performance Evaluations - for OBT program managers. Develop criteria on technology transfer activities by which program managers' performance would be assessed. Create a OBT policy that program managers' performance on technology transfer would be taken into account in recommendations for salary increases and promotions. Staff. (Proposed)

(4), 44, 6.3 


\section{OBT Management Support of Technology Transfer (concluded)}

Rank

13/14 M. Annual overall OBT technology transfer plan - for OBT program management. This task would involve gathering information from program managers about technology transfer plans and developing a milestone schedule of technology transfer products and events. The person assigned to this task would track the milestone accomplishments and report periodically to management about technology transfer progress. Staff and support: $\$ 25,000$. (Proposed)

(3), 37, 5.3

0 N. Division of Technology Transfer within OBT - for OBT program management. The staff of this division would review all OBT reports from a technology transfer point of view and recommend how the material developed by OBT and its national laboratory staff should be used. $\$ 500,000$ first year. (Proposed)

26 O. Internal technology transfer team - for OBT program management. The team would be created by appointing someone in each division to be responsible for technology transfer activities at the division level, to work with someone at the office level. This group would meet at least quarterly to report on progress and review technology transfer activities. Also, this effort would promote intemal technology transfer by establishing a quarterly or semi-annual session among program managers to communicate what is going on, possible redundancies, cost-sharing opportunities, and technology transfer efforts. Periodic information meetings would be held at OBT to inform program managers of OBT Technology Transfer Program activities. The technology transfer plans of individual program managers would be discussed during informal meetings. Staff. (Proposed) (2), 20, 2.9

47. P. Broker Organizations Data Base - for OBT program management. Each national laboratory maintains a mailing list of buildings-related trade and professional organizations, as do OBT, AlA, and other organizations. These organizations can serve as potential pathways for the transfer of information and technologies to targeted member audiences. The OBT technology transfer program needs ready access to broker organization contact information if it is to assist OBT program managers in real time with suggestions about whom to contact for day-to-day problems in transferring technology as they arise. A data base of broker organizations would be established on a PC at headquarters, with sets and updates available to the national labs. Broader attack on the mailing issue is needed. $\$ 18,000$. (Proposed)

(1), $4,0.6$

\section{Research in Support of Technology Transfer}

46 B. Innovation case studies - for program managers. Produced statistics on market penetration that have been used several times already as evidence of success. ORNL completed 12, and three case studies are pending on how buildings program technologies diffused successfully (reached 5\% of market)。 Commercializing Govemment-Sponsored Innovations: Twelve Successful Buildings Case Studies. 1989. Annual: $\$ 30,000$. Cumulative: $\$ 120,000$ (4 years). (Existing)

(1), $5,0.7$ 


\section{Research in Support of Technology Transfer (continued)}

\section{Rank}

34 G. Literature Review on the Effectiveness of Technology Transfer Approaches - for technology transfer planning at the program, division, and national-laboratory levels. Existing literature on education, communications, diffusion of innovations, hazards wamings, and technology transfer contains results of empirical studies conceming the most effective approaches to transferring scientific and technological information. The literature will be examined, particularly for existing reviews of literature, for generalizations that could be used to evaluate existing efforts, and as a basis for designing future OBT technology transfer activities. \$25,000. (Proposed)

(1), 14, 2

22/23 H. Needs assessment/market analysis/mformation outreach - for buildings designers. Could be performed to discover whether CD-ROM or Sweet's Catalog would be more effective in reaching the intended user audiences. ASHRAE, which publishes handbooks, and LBL, which is developing CAD design tools, might be partners in the needs assessment. \$25,000. (Proposed)

(2), 24, 3.4

9 I. Develop an Evaluation Design for Technology Transfer Programs - Information dissemination programs such as CAREIRS, NATAS, and STIP have not been evaluated for their effectiveness in reaching consumer and other information users and in affecting energy efficiency behavior. A small group of national laboratory researchers will convene to consider the research design problem involved in evaluating a complex, mature information program. The group will produce a quasi-experimental research design that can be applied, perhaps with only slight modifications, to any of the information and other technology transfer programs. \$15,000. (Proposed)

(4), 48, 6.9

10 J. Evaluation of technology transfer effectiveness - Indicators of the effectiveness of OBT technology transfer activities will be compiled and a system will be developed for periodically updating them. Requests for information resulting from articles in trade joumals, OBT Research-in-Progress, and other publications will be monitored. Information conceming the number and nature of requests for CAREIRS fact sheets and assistance from NATAS and SERI's Technical Inquiry Service will be analyzed. Statistics will be compiled on other indicators, such as the number of copies of OBT software packages sold through the National Energy Software Centers, the number of users of the OSTI standard distribution list for reports, and the number of requests for technical reports from NTIS. Such evaluation measures will help direct the program's future technology transfer activities. \$25,000 (Proposed)

(3), $45,6.4$ 


\section{Research in Support of Technology Transfer (continued)}

$\underline{\text { Rank }}$

42/43 K. Inventory of Technology Transfer Activities and Lab Reviews - The idea behind this suggestion was to get a better understanding of currently funded OBT technology transfer mechanisms in terms of their scope, effectiveness, and linkage to other activities (i.e., leveraging potential), and to increase the importance of technology transfer relative to other programmatic activities by increasing its viability and emphasis. This would be accomplished in two phases. The first phase would be to conduct a thorough inventory of exactly what technology transfer activities are currently funded and ongoing, both program-wide and at the division and laboratory levels. Evaluation and reconciliation of these activities would take place while looking for overlaps, effectiveness, appropriateness, and opportunities for leveraging. The second phase, listed in management support activities, would involve annual reviews of technology transfer at the lab reviews. Establishing the inventory of current technology transfer activities would constitute most of the effort. \$20,000. (Proposed)

(1), 8, 1.1

0 L. Technology Transfer Case Studies in the Private Sector - This is basically a literature and personal network survey activity. It should only involve a week at the most to complete, if knowledgeable persons are chosen to do the search and calls. Basically, there are case studies of successful technology transfer programs in the private sector that should be documented from the federal govemment perspective. Technology transfer monies have supported several corporate public relations fims to develop articles on DOE/OBT enduser research. They are the first that should be tapped for other corporate case studies. The computer industry is also a prime source of technology transfer success models. Such companies as Apple, Hewlett-Packard, and IBM could provide robust models. The purpose of this survey activity should be to first collect the stories and then follow up with a personal contact, possibly drawing in individuals from those corporations or their public relations firms as possible members of OBT's Technical Review Panel (TRP) on Technology Transfer. \$10,000. (Proposed)

49 M. Study successful past technology transfer activities - for OBT program management. This involves identifying successful technology transfer activities from 10 years ago by interviewing those with an institutional memory and disceming which of these might be useful as models for future activities. \$12,000. (Proposed)

(1), $1,0.1$

7 N. Research on Segmentation of OBT User Audiences - for OBT program management. Fragmentation of the buildings industries has been cited so often as a barrier to energy efficiency in buildings that it has become a truism. Users are diverse, and no single avenue of technology transfer could reach more than a few of them. Each part of the potential OBT audience needs to be defined and characterized, and a research and technology transfer strategy developed to meet its particular needs. A way of approaching this segmentation process is to classify user groups-oproduct manufacturers, for example, and intermediaries--associated with each technology being developed. 
3. Research in Support of Technology Transfer (concluded)

$\underline{\text { Rank }}$

For example, lamp manufacture is probably accomplished by six or fewer companies. This task would define how to get lighting innovations adopted by the lamp manufacturers; identify how to get the related ballast innovations adopted by fixture manufacturers; identify how lamping distributors can be induced to sell the new products; identify the utility company's interest in distributing energy efficient lighting; research how lighting is installed, operated, and maintained within commercial buildings; and identify how to affect those processes to achieve an energy-efficient outcome. This research could be done for other technologies, as OBT management deems appropriate. $\$ 55,000$. (Proposed) (7), 64, 9.1

4. Special Activities

3 A. Center for the Analysis and Dissemination of Demonstrated Energy Technologies (CADDET) - for intermediaries and program implementers in member countries. Established by the Intemational Energy Agency (IEA). Denmark, Sweden, Finland, Italy, Netherlands, Norway, Switzerland, United Kingdom, United States, Canada, New Zealand are members. Goal is the adoption by industry of successful energy efficiency technologies. Are developing a database of demonstration projects; is publishing a newsletter, has produced four analysis reports and 40 brochures (one per demonstrated technology, including six from the U.S.). ORNL is the lead U.S. lab. Annual: $\$ 80,000$; $\$ 155,000$ goes to CADDET. Cumulative $\$ 235,000$. (Existing)

(6), 93, 13.3

48 B. OBT-State-initiative - for state energy offices. Jon Stone was attempting to document BCS R\&D products for state energy offices to let them know what the national laboratories could do; however, the product from this effort has not been approved for distribution by upper DOE management. The project is now dormant. Annual: $\$ 7500$. Cumulative: $\$ 15,000$ (two times). (Discontinued)

(1), 3, 0.4

35 C. Summer Institute on Energy and Design - for architecture faculty. To maintain awareness among architecture faculty of energy as a major curricular issue, the Institute will be conducted to provide university faculty with resources to teach architecture students how to design energy-efficient buildings. The Institute will also inform design faculty of current OBT R\&D activities, and will provide a forum for the exchange of information on the future research agenda of govermment, private industry, and the academic community. Was held annually from 1980-1987; again in 1989; and is planned for 1991. Forty faculty attend the Institute. Annual: $\$ 100,000$. Cumulative: $\$ 800,000$ (8 years). (Existing) (3), $13 ; 1.9$

21 D. Institute on Energy and Engineering Education - for mechanical engineering faculty. BTECC puts on the Institute for mechanical engineering faculty; 21 attended last institute. Was held annually from 1980 through 1986; again in 1988; and is planned for 1990. Semiannual: $\$ 100,000$. Cumulative: $\$ 800,000$ from OBT. (Existing) (4), 24, 3.4

0 E. SBSE Institute. The Society of Building Science Educators has proposed a substitute for the energy design institute for architecture faculty, drawing on lab researchers. Note: Relates to the Summer Institute on Energy Design and to the National Laboratory Hosts of the ACSA Summer Institute on Energy and Environmental System. Assume comparable funding of $\$ 100,000$. (Proposed) 


\section{Special Activities (continued)}

Rank

31 F. Outreach to Home Improvement Centers - for do-it-yourselfers. Develop a plan and implement a pilot project to place CAREIRS fact shoets in lumber and home improvement companies. This could involve reprints of the fact sheets by a publishing company (e.g., Whittle Communication in Knoxville). The publisher could recoup some of its costs by charging a nominal fee for each fact sheet. \$25,000. (Proposed)

(2), 17, 2.4

19 G. Implementing Advanced Building Technologies by Adopting Architectural Firms as Information Brokers - (including personnel switches, workshops, awards) for building designers. Major A/E firms in this country conduct building design research to solve design problems but often do not publicize this fact. A case in point is the firm of Murphy-Jahn in Chicago. For their design of the United Airlines Terminal at O'Hare International Airport, they were challenged by the local building officials to defend their use of exposed steel and vast amounts of glazed roof. They went back to the drawing boards, came up with acceptable technical solutions to support their approach and received approval. At completion, the vast complex won architectural and design awards for their bold, inventive solutions.

For the most part, this experience is lost as an information and technology transfer opportunity by DOE. It is also a lost leaming opportunity for building industry professionals at large. Initially, OBT could establish a dialogue mechanism between DOE/OBT-supported researchers and AVE firms to form joint building technology application "partnerships" in the early phases of a design commission. For instance, OBT technology transfer could support a design-technology collaboration between LBL's Windows and Daylighting Group and Murphy-Jahn Architects to develop and apply advanced window technologies to their next high-rise office tower. The information from this collaboration could be documented for case studies and design joumal articles and funneled into a multi-media computer-based leaming kiosk for dissemination to building industry trade organizations. Firms could receive a research award for doing research on building technologies. $\$ 50,000$. (Proposed)

(3), $26,3.7$

15 H. National Laboratory Host ACSA Summer Institute on Energy and Environmental Systems. For the past 10 years, BCS had sponsored the ACSA Summer Institutes, influencing several hundred architectural faculty on the issues of energy conservation and building design. Consistently, these institutes have taken place on college campuses. The next series of institutes should be hosted by the three or four national laboratories conducting building energy research, for the express interest of fostering a better understanding of the research environment for architectural professors. DOE's industry R\&D exchange or the successful LBL summer educator programs could be used as planning and implementation models.

The first change of venue could be LBL, hosted by the Windows and Daylighting Group, with LBL's Center for Engineering \& Science Education contracted to manage the institute. Professors would have the opporturnity to be exposed to a wide range of teaching and curriculum development resources, i.e., Lawrence Hall of Science. The theme of the first laboratory-based institute could be "exploring the development and use of advanced computer-based designer workstations for the year 2000." Note: Relates to the Summer Institute on Energy and Design. Staff and \$10,000. (Proposed).

(3), 30, 4.3 


\section{Special Activities (concluded)}

\section{Rank}

0 I. Institute for Government Energy Ofincials - for federal govemment building managers. (Note: GSA already does training, and NIST has a symposium series.) This idea is to hold institutes, modeled after the ones that have been held for architects and engineers, for federal, state, and local officials responsible for the design, construction, operation, and maintenance of government buildings. OBT would involve the Society of Building Science Educators (SBSE) to participate in curriculum development and to recruit staff for the courses. There is no course for government officials comparable to the institute's. A series of topics would be covered, including daylighting, window design, ASEAM, auditing, and so on. The project would seek collaboration and coordination with FEMP, OTFA, and any other groups that should appropriately be involved. Marvin Gorelick, in the Building Systems Division, is interested in developing and pursuing this idea. Staff and \$10,000 (Proposed)

45 J. Star recognition model - for major corporate adopters. The purpose is to stimulate corporate adoption of energy efficiency in buildings through corporate opinion leaders to demonstrate and advertise what they are doing in energy efficiency. This is a strategy to induce large demand advertising (use of models and shills). It uses an award model based on the ASHRAE award and the AIA awand. OBT could combine licensing with advertising the name of the contractor who did the work for, say, Marriott or any other corporation. This would have more impact on building owners, managers, and operators. $\$ 25,000$. (Proposed)

(1), 6, 0.9 


\section{SEPI 충}

\section{APPENDIX F \\ Framework Used to Systematize Activities}


Table F-1. Existing and Proposed Technology Transfer Activities

Matrix classified by

1. Technology Transfer Functions

- $\quad$ Research Results

- New and Existing OBT Tools, Technologies and Practices

- New and Existing non-OBT Tools, Technologies, and Practices

- Program Awareness

- Management and Research Support

2. Target Audiences

Building researchers (nationwide)

Federal

Buildings

Conservation programs

Legislative concems

State and local

Buildings

Conservation programs

Legislative concems

Private sector

Product manufacturers and distributors

Energy intermediaries

Conservation programs

Consumers/end users

Intemal DOE (OBT and up) and laboratories 


\section{Table F-2. Technology Transfer Activities}

Technology Transfer Functions

$\begin{array}{ll}\text { New and Existing } & \text { New and Existing } \\ \text { OBT Tools, } & \text { non-OBT Tools, } \\ \text { Technologies, } & \text { Technologies, }\end{array}$

\begin{tabular}{|c|c|}
\hline $\begin{array}{l}\text { Target } \\
\text { Audiences }\end{array}$ & $\begin{array}{l}\text { Research } \\
\text { Results }\end{array}$ \\
\hline \multirow[t]{4}{*}{$\begin{array}{l}\text { Buildings } \\
\text { Researchers }\end{array}$} & $\begin{array}{l}\text { Database inquiry } \\
\text { service }(22 / 23)^{*}\end{array}$ \\
\hline & $\begin{array}{l}\text { Buildings Energy } \\
\text { Technology (24) }\end{array}$ \\
\hline & $\frac{\text { Research in }}{\text { Progress (25) }}$ \\
\hline & $\frac{\text { Recent Publica- }}{\text { tions of DOE's }}$ \\
\hline 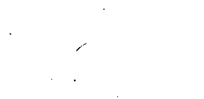 & $\begin{array}{l}\text { ings and Community } \\
\text { Systems (29) }\end{array}$ \\
\hline
\end{tabular}

(1) and Practices

and Practices

Building Efficiency

and Conservation

Building Efficiency

and Conservation

Network (BEACON) (5)

Network (BEACON) (5)

\section{Program \\ Awareness}

Technology Briefs

(Program Over-

views) (27)

Program Overviews

(28)

Public relations

work at DOE and the labs (36)

\section{A Compendium of \\ Energy Conservation Success Stories (37)}

"In-progress report" (39)

*Numbers in parentheses are ranks given by the Technology Transfer Advisory Group. 
Table F-2. Teclmology Transfer Activities (continued)

Technology Transfer Functions

\section{Target Research \\ Audiences : Results}

Federal

Buildings

\section{New and Existing non-OBT Tools, \\ Technologies, \\ and Practices}

Program

Technologies,

and Practices

Center for the

Analysis and

Dissemination of

Demonstrated Energy

Technologies

(CADDET) (3)

Building Efficiency

and Conservation

Network (BEACON)

(5)

Demonstration project funded by all three divisions (30)

Institute for

Government Energy

Officials (0)

\section{Center for the}

Analysis and

Dissemination of

Demonstrated Energy

Technologies

(CADDET) (3)

Building Efficiency

and Conservation

Network (BEACON)

(5)

Demonstration project funded by all three divisions (30)

Institute for

Government Energy

Officials (0) 
Table F-2. Technology Transfer Activities (continued)

Technology Transfer Functions

\section{Target \\ Audiences \\ Research \\ Results}

Federal

Conservation

Programs
New and Existing

OBT Tools,

Technologies,

and Practices

Center for the

Analysis and

Dissemination of

Demonstrated Energy

Technologies

(CADDET) (3)

Building Efficiency

and Conservation

Network (BEACON)

(5)

Energy Conservation

Technical Informa-

tion Guide, Commer-

cial Buildings (38)

Research Update -

Existing Buildings

Efficiency Research

(EBER) (0)

Publication support

to and from state

energy offices (SEOs)

(0)
New and Existing non-OBT Tools,

Technologies,

and Practices

Program

Awareness

Center for the

Analysis and

Dissemination of

Demonstrated Energy

Technologies

(CADDET) (3)

Building Efficiency

and Conservation

Network (BEACON)

(5)

Energy Conservation

Technical Informa-

tion Guide, Commer-

cial Buildings (38)

Research Update -

Existing Buildings

Efficiency Research

(EBER) (0)

Publication support

to and from SEOs

(0) 
Table F-2. Technology Transfer Activities (continued)

Technology Transfer Functions

Target Research

Audiences $\quad \underline{\text { Results }}$

Federal

Legislative

Concems
New and Existing non-OBT Tools,

OBT Tools,

Technologies,

and Practices
Technologies,

and Practices

\section{Program}

Awareness

Technology Briefs

(Program Over-

views) (27)

Program Overviews

(28)

Public relations

work at DOE and

the labs (36)

\section{A Compendium of} Energy Conservation

Success Stories (37) 
Table F-2. Technology Transfer Activities (continued)

Technology Transfer Functions

$\begin{array}{ll}\text { Target } & \text { Research } \\ \text { Audiences } & \underline{\text { Results }}\end{array}$

State and Local

Buildings
New and Existing

OBT Tools,

Technologies,

and Practices

Center for the

Analysis and

Dissemination of

Demonstrated Energy

Technologies

(CADDET) (3)

Building Efficiency

and Conservation

Network (BEACON) (5)

Demonstration

project funded by

all three divisions

(30)

\section{New and Existing non-OBT Tools, \\ Technologies, \\ and Practices}

Center for the

Analysis and

Dissemination of

Demonstrated Energy

Technologies

(CADDET) (3)

Building Efficiency

and Conservation

Network (BEACON) (5)

Demonstration

project funded by

all three divisions

(30)
Program

Awareness 
Table F-2. Technology Transfer Activities (continued)

Technology Transfer Functions

\section{Target Research \\ Audiences \\ Results}

State and Local

Conservation

Programs

\section{New and Existing \\ OBT Tools, \\ Technologies, \\ and Practices}

Center for the

Analysis and

Dissemination of

Demonstrated Energy

Technologies

(CADDET) (3)

Building Efficiency

and Conservation

Network (BEACON) (5)

ASEAM-2.1 technology

transfer (33)

Energy Conservation

Technical Informa-

tion Guide, Commer-

cial Buildings (38)

OBT-State

initiative (47)

Research Update -

Existing Buildings

Efficiency Research

(EBER) (0)

Publication support

to and from SEOs (0)

\author{
New and Existing \\ non-OBT Tools, \\ Technologies, \\ and Practices \\ Program \\ Awareness
}

Center for the

Analysis and

Dissemination of

Demonstrated Energy

Technologies

(CADDET) (3)

Building Efficiency

and Conservation

Network (BEACON) (5)

Energy Conservation

Technical Informa-

tion Guide, Commer-

cial Buildings (38)

OBT-State

initiative (47)

Research Update -

Existing Buildings

Efficiency Research

(EBER) (0)

Publication support

to and from SEOs (0) 
Table F-2. Technology Transfer Activities (continued)

Technology Transfer Functions

\section{New and Existing \\ New and Existing}

OBT Tools,

Target Research

Audiences Results

State and Local

Legislative

Concerns non-OBT Tools,

Technologies,

and Practices
Program

Awareness

Technology Briefs

(Program Over-

views) (27)

Program Overviews

(28)

Public relations work at DOE and the labs (36)

A Compendium of Energy Conservation Success Stories (37) 
Table F-2. Technology Transfer Activities (continued)

Technology Transfer Functions

\begin{tabular}{|c|c|c|c|c|}
\hline $\begin{array}{l}\text { Target } \\
\text { Audiences } \\
\end{array}$ & $\begin{array}{l}\text { Research } \\
\text { Results }\end{array}$ & $\begin{array}{l}\text { New and Existing } \\
\text { OBT Tools, } \\
\text { Technologies, } \\
\text { and Practices }\end{array}$ & $\begin{array}{l}\text { New and Existing } \\
\text { non-OBT Tools, } \\
\text { Technologies, } \\
\text { and Practices }\end{array}$ & $\begin{array}{l}\text { Program } \\
\text { Awareness }\end{array}$ \\
\hline $\begin{array}{l}\text { Product } \\
\text { Manufacturers } \\
\text { and Distributors }\end{array}$ & $\begin{array}{l}\text { Institute on Energy } \\
\text { and Engineering } \\
\text { Education (21) } \\
\text { Summer Institute on } \\
\text { Energy and Design } \\
\text { (35) } \\
\text { Building energy } \\
\text { case study curri- } \\
\text { culum materials } \\
\text { (41/42) }\end{array}$ & $\begin{array}{l}\text { Center for the } \\
\text { Analysis and } \\
\text { Dissemination of } \\
\text { Demonstrated Energy } \\
\text { Technologies } \\
\text { (CADDET) (3) } \\
\text { Trade magazine news } \\
\text { releases and } \\
\text { articles (4) } \\
\text { Curriculum mate- } \\
\text { rials for technical } \\
\text { schools (18) } \\
\text { Implementing } \\
\text { advanced building } \\
\text { technologies by } \\
\text { adopting archi- } \\
\text { tectural firms as } \\
\text { information brokers } \\
\text { (19) } \\
\text { Institute on Energy } \\
\text { and Engineering } \\
\text { Education (21) }\end{array}$ & $\begin{array}{l}\text { Center for the } \\
\text { Analysis and } \\
\text { Dissemination of } \\
\text { Demonstrated Energy } \\
\text { Technologies } \\
\text { (CADDET) (3) } \\
\text { Trade magazine news } \\
\text { releases and } \\
\text { articles (4) } \\
\text { Curriculum mate- } \\
\text { rials for technical } \\
\text { schools (18) } \\
\text { Implementing } \\
\text { advanced building } \\
\text { technologies by } \\
\text { adopting archi- } \\
\text { tectural firms as } \\
\text { information brokers } \\
\text { (19) } \\
\text { Institute on Energy } \\
\text { and Engineering } \\
\text { Education (21) }\end{array}$ & $\begin{array}{l}\text { Technical review } \\
\text { panel (0) } \\
\text { Modular display of } \\
\text { OBT research } \\
\text { accomplishments (8) } \\
\text { Information kiosk } \\
\text { on the OBT program } \\
\text { (17) } \\
\text { Technology Briefs } \\
\text { (Program Over- } \\
\text { views) (27) } \\
\text { Program Overviews } \\
\text { (28) } \\
\text { "In-progress report" } \\
\text { (39) }\end{array}$ \\
\hline
\end{tabular}

Trade magazine news releases and

Curriculum mate-

\author{
New and Existing \\ non-OBT Tools, \\ Technologies, \\ lysis and \\ Technologies
}

Trade magazine news

releases and

rials for technical

anced building

tectural firms as

information brokers

Institute on Energy

Education (21) 
Table F-2. Technology Transfer Activities (continued)

Technology Transfer Functions

\section{Target \\ Research \\ Audiences \\ $\underline{\text { Results }}$}

\section{Product}

Manufacturers

and Distributors

(concluded)
New and Existing

OBT Tools,

Technologies,

and Practices

ASEAM-2.1 tech-

nology transfer

(33)

Summer Institute on

Energy and Design

Building energy

case study curri-

culum materials

(41/42)

Research Update -

Existing Buildings

Efficiency Research

(EBER) (0)
New and Existing non-OBT Tools,

Technologies,

Program

and Practices

Awareness

Summer Institute on

Energy and Design

(35)

Building energy

case study curri-

culum materials

(41/42)

Research Update -

Existing Buildings

Efficiency Research

(EBER) (0) 
Table F-2. Technology Transfer Activities (continued)

Technology Transfer Functions

\section{Target \\ Audiences \\ Private-Sector \\ Energy}

Research

Results

Intermediaries

\begin{tabular}{ll}
$\begin{array}{l}\text { New and Existing } \\
\text { OBT Tools, } \\
\text { Technologies, } \\
\text { and Practices }\end{array}$ & $\begin{array}{l}\text { New and Existing } \\
\text { non-OBT Tools, } \\
\text { Technologies, } \\
\text { and Practices }\end{array}$ \\
\hline Center for the & Center for the \\
Analysis and & Analysis and \\
Dissemination of & Dissemination of \\
Demonstrated Energy & $\begin{array}{l}\text { Demonstrated Energy } \\
\text { Technologies }\end{array}$ \\
(CADDET) (3) & (CADDET) (3)
\end{tabular}

Trade magazine news releases and

articles (4)

Building Efficiency

and Conservation

Network (BEACON)

Computer-based

information systems

for technology

transfer (13/14)

National laboratory

host ACSA Summer

Institute on Energy

and Environmental

Systems (15)

Energy Scheming-1.0

(32)

ASEAM-2.1 tech-

nology transfer (33)
Trade magazine news

releases and

articles (4)

Building Efficiency

and Conservation

Network (BEACON) (5)

Computer-based

information systems

for technology

transfer (13/14)

National laboratory

host ACSA Summer

Institute on Energy

and Environmental

Systems (15)

Research Update -

Existing Buildings

Efficiency Research

(EBER) (0)

\section{Program}

Awareness

Technical review panel (6)

Modular display of OBT research

accomplishments (8)

Information liosk on the OBT program (17)

Technology Briefs (Program Overviews) (27)

Program Overviews (28)

"In-progress report" 
Table F-2. Technology Transfer Activities (continued)

Technology Transfer Functions

\section{Target \\ Audiences \\ Private-Sector \\ Energy \\ Intermediaries \\ (concluded)}

Research

Results
New and Existing

OBT Tools,

Technologies,

and Practices

Research Update -

Existing Buildings

Efficiency Research

(EBER) (0)

SOLAR-5 (a micro-

computer energy-

conserving design

tool) (0)

SBSE Institute (0)
New and Existing

non-OBT Tools,

Technologies,

and Practices

Program

Awareness

SOLAR-5 (a micro-

computer energy-

conserving design

tool) (0)

SBSE Institute (0) 
Table F-2. Technology Transfer Activities (continued)

Technology Transfer Functions

Target Research

Audiences . Results

Private-Sector

Conservation

Programs
New and Existing

OBT Tools,

Technologies,

and Practices

Center for the

Analysis and

Dissemination of

Demonstrated Energy

Technologies

(CADDET) (3)

Trade magazine news

releases and

articles (4)

Building Efficiency

and Conservation

Network (BEACON) (5)

ASEAM-2.1 technology transfer (33)

Energy Conservation

Technical Informa-

tion Guide, Commer-

cial Buildings (38)

Research Update -

Existing Buildings

Efficiency Research

(EBER) (0)
New and Existing

non-OBT Tools,

Technologies,

and Practices

Program

Awareness

Center for the

Analysis and

Dissemination of

Demonstrated Energy

Technologies

(CADDET) (3)

Trade magazine news

releases and

articles (4)

Building Efficiency

and Conservation

Network (BEACON) (5)

Energy Conservation-

Technical Informa-

tion Guide, Commer-

cial Buildings (38)

Research Update -

Existing Buildings

Efficiency Research

(EBER) (0) 
Table F-2. Technology Transfer Activities (continued)

Technology Transfer Functions

\section{Target \\ Audiences \\ Research \\ $\underline{\text { Results }}$}

Consumers/

Energy Users
New and Existing

OBT Tools,

Technologies,

and Practices

Building Efficiency

and Conservation

Network (BEACON) (5)

Outreach to home

improvement centers

(31)

Star recognition

model (44)

\section{New and Existing non-OBT Tools, \\ Technologies, \\ and Practices}

Building Efficiency

and Conservation

Network (BEACON) (5)

Outreach to home

improvement centers

(31)

Star recognition

model (44)
Program

Awareness

Technology Briefs

(Program Over-

views) (27)

Program Overviews

(28)

Public relations work at DOE and the labs (36)

A Compendium of Energy Conservation

Success Stories (37) 
Table F-2. Technology Transfer Activities (continued)

Technology Transfer Functions

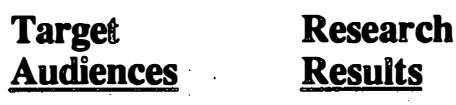

Internal DOE

(OBT \& up)

\section{New and Existing}

OBT Tools,

Technologies,

and Practices

\section{New and Existing} non-OBT Tools,

Technologies,

and Practices studies (45)panel (6)

Technology transfer

in performance

evaluations (11)

Provide technical

assistance and

require a technology

transfer plan as part

of all R\&D projects

(12)

Annual overall OBT

technology transfer

plan $(13 / 14)$

OBT technology transfer award (16)

\section{Program}

Public relationsManagement Support:

A Compendium of

Energy Conserva-OBT technology tion Successtransfer roundtable Stories (37)(2) 
Table F-2. Technology Transfer Activities (continued)

Technology Transfer Functions

\begin{tabular}{ll}
$\begin{array}{l}\text { Target } \\
\text { Audiences }\end{array}$ & $\begin{array}{l}\text { Research } \\
\text { Results }\end{array}$ \\
\hline
\end{tabular}

$\underline{\text { Results }}$

Intemal DOE

(OBT \& up)

(continued)

\section{New and Existing non-OBT Tools, \\ Technologies, \\ and Practices}

New and Existing

TOols,

and Practices

\section{Program}

Awareness

Electronic mail

network for OBT and

its national labora-

tories (20)

Internal technology

transfer team (26)

Division of tech-

nology transfer

within OBT (0)

Research Support:

Research on segmentation of OBT user audiences ( 7 )

Develop an evaluation design for technology transfer programs (9)

Evaluation of technology transfer effectiveness (10)

Needs assessment/ market analysis (22/23) 
Table F-2. Technology Transfer Activities (concluded)

Technology Transfer Functions

\section{Target Research \\ Audiences Results}

Internal DOE

(OBT \& up)

(concluded)
New and Existing

OBT Tools,

Technologies,

and Practices
New and Existing

non-OBT Tools,

Technologies;

and Practices

\section{Program}

Awareness

Literature review on the effectiveness of technology transfer approaches (34)

List of building trade publications (40)

Inventory of technology transfer activities and lab reviews (41/42)

International residential energy use data base (43)

Broker organizations data base (46)

Study successful past technology transfer activities (48)

Technology transfer case studies in the private sector (0) 


\begin{tabular}{|c|c|c|}
\hline $\begin{array}{l}\text { Document Control } \\
\text { Page }\end{array}$ & \begin{tabular}{|l|l|} 
1. SEAI Report No. & 2. NTIS Accession No. \\
SERI/TP-260-3729 & DE90000347 \\
\end{tabular} & 3. Recipient's Accession No. \\
\hline \multicolumn{2}{|l|}{ 4. Title and Subtitle } & 5. Publication Date \\
\hline \multirow{2}{*}{\multicolumn{2}{|c|}{$\begin{array}{l}\text { A Planning Framework for -Transferring Building } \\
\text { Energy Technologies }\end{array}$}} & July 1990 \\
\hline & & 6. \\
\hline \multicolumn{2}{|c|}{ 7. Author(s) Barbara C. Farhar, Marilyn A. Brown, Bryan L. } & 8. Performing Organization Rept. No. \\
\hline \multirow{2}{*}{\multicolumn{2}{|c|}{$\begin{array}{l}\text { 9. Performing Organization Name and Address } \\
\text { Solar Energy Research Institute } \\
1617 \text { Cole Boulevard } \\
\text { Golden, Colorado } 80401-3393\end{array}$}} & $\begin{array}{l}\text { 10. ProjecttTask/Work Unit No. } \\
\text { AS925440 }\end{array}$ \\
\hline & & $\begin{array}{l}\text { 11. Contract (C) or Grant (G) No. } \\
\text { (C) } \\
\text { (G) }\end{array}$ \\
\hline \multicolumn{2}{|c|}{ 12. Sponsoring Organization Name and Address } & $\begin{array}{l}\text { 13. Type of Report \& Period Covered } \\
\text { Technical Report }\end{array}$ \\
\hline & & 14. \\
\hline \multicolumn{3}{|l|}{ 15. Supplementary Notes } \\
\hline \multicolumn{3}{|c|}{$\begin{array}{l}\text { 16. Abstract (Limit: } 200 \text { words) } \\
\text { Accelerating the adoption of new and existing cost-effective technologies has } \\
\text { significant potential to reduce the energy consumed in U.S. buildings. This report } \\
\text { presents key results of an interlaboratory technology transfer planning effort in } \\
\text { support of the U.S. Department of Energy's office of Building Technologies (OBT). } \\
\text { A guiding assumption for planning was that OBT's R\&D program should forge linkages } \\
\text { with existing programs whose goals involved enhancing energy efficiency in buildings. } \\
\text { An ad hoc Technology Transfer Advisory Group reviewed the existing analysis and } \\
\text { technology transfer program, brainstormed tehcnology transfer approaches, interviewe } \\
\text { DOE program managers, identified applicable research results, and developed a frame- } \\
\text { work that management could use in deciding on the best investiments of technology } \\
\text { transfer resources, Representatives of } 22 \text { organizations were interviewed on their } \\
\text { yiews of the potential for transferring energy efficiency technologies through activ } \\
\text { linking with OBT. The report describes these programs and interview results; outline } \\
\text { OBT tools, technologies, and practices to be transferred; defines OBT audiences; } \\
\text { identifies technology transfer functions and presents a framework devised using } \\
\text { functions and audiences; presents some } 60 \text { example technology transfer activities; } \\
\text { and documents the Advisory Group's recomendations. }\end{array}$} \\
\hline \multicolumn{3}{|c|}{$\begin{array}{l}\text { 17. Document Analysis } \\
\text { a. Descriptors } \\
\text { Energy efficiency ; buildings ; technology transfer ; information } \\
\text { dissemination; US DOE ; Solar Energy Research Institute }\end{array}$} \\
\hline \multicolumn{3}{|c|}{ b. Identifiers/Open-Ended Terms } \\
\hline \multicolumn{3}{|l|}{ c. UC Categories } \\
\hline \multicolumn{3}{|l|}{233} \\
\hline \multicolumn{2}{|c|}{ 18. Availability Statement } & 19. No. of Pages \\
\hline \multirow{2}{*}{\multicolumn{2}{|c|}{$\begin{array}{l}\text { National Technical Information Service } \\
\text { U.S. Department of Commerce } \\
5285 \text { Port Royal Road } \\
\text { Springfield, Virginia } 22161\end{array}$}} & 200 \\
\hline & & 20. Price \\
\hline 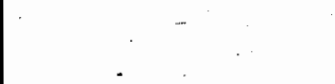 & 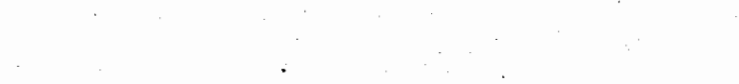 & A09 \\
\hline
\end{tabular}

